Portland State University

PDXScholar

1989

\title{
A Comparison of Assistant Principal and Principal Perceptions of the Assistant Principalship as a Training Ground in the Secondary School
}

Patricia Ann Howell

Portland State University

Follow this and additional works at: https://pdxscholar.library.pdx.edu/open_access_etds Let us know how access to this document benefits you.

\section{Recommended Citation}

Howell, Patricia Ann, "A Comparison of Assistant Principal and Principal Perceptions of the Assistant Principalship as a Training Ground in the Secondary School" (1989). Dissertations and Theses. Paper 1373.

https://doi.org/10.15760/etd.1372

This Dissertation is brought to you for free and open access. It has been accepted for inclusion in Dissertations and Theses by an authorized administrator of PDXScholar. Please contact us if we can make this document more accessible: pdxscholar@pdx.edu. 


\title{
A COMPARISON OF ASSISTANT PRINCIPAL AND PRINCIPAL PERCEPTIONS OF THE ASSISTANT PRINCIPALSHIP AS A TRAINING GROLND IN THE SECONDARY SCHOOL
}

bỵ

PATRICIA ANA HOHELL

\begin{abstract}
A dissertation submitted in partial fulfillment of the requirements for the degree of

\author{
DOCTOR OF EDUCATION \\ in \\ EDUCATIONAL LEADERSHIP
}

Portland State University

1989 
TU THE UFFICE OF GRAUATE STLDIES ARD RESEARCH:

The mentics: of the Committee approve the dissertation of Hatricia Arn Hovell presented April 24, 1989.

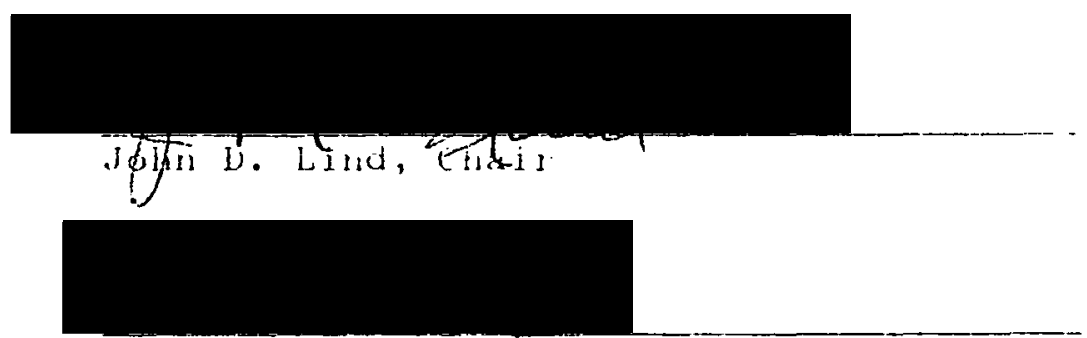

Carrol Tama

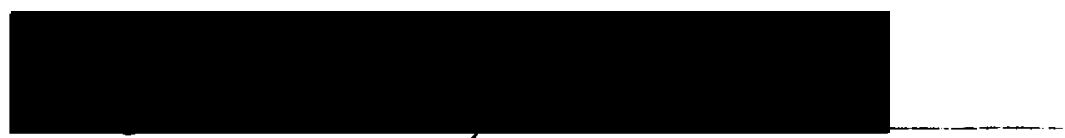

Carol Fetermai:

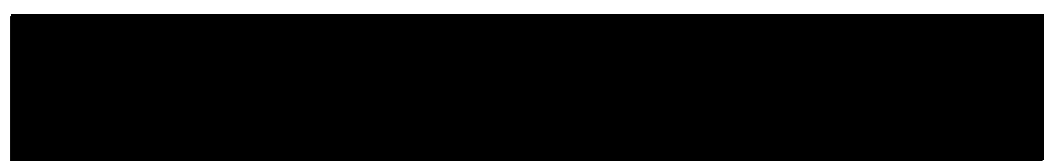

Maxine Thomas

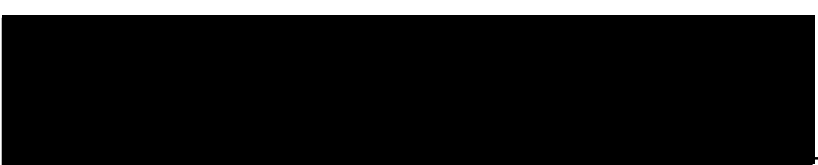

Gerald Guthrie

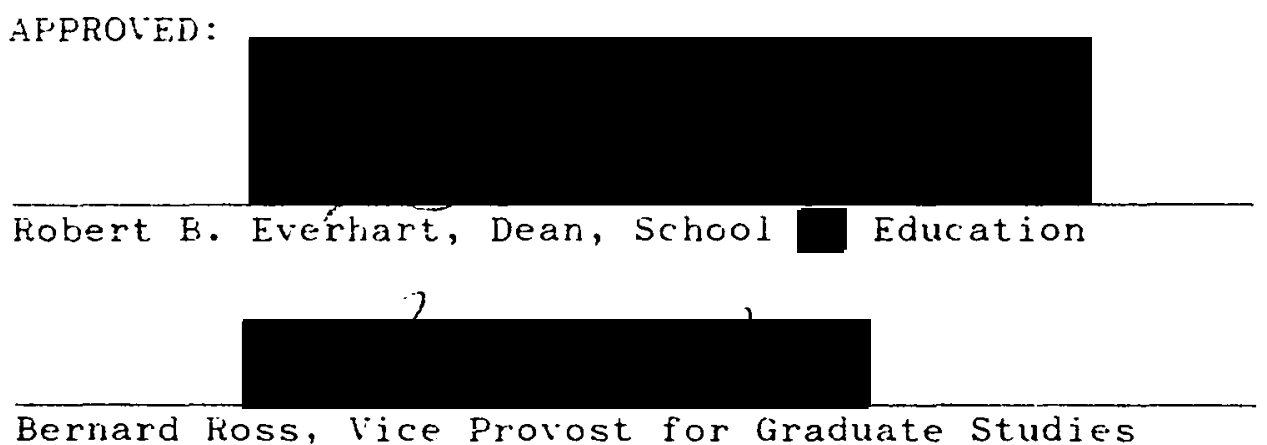




\section{TABLE OF CONTENTS}

PAGE

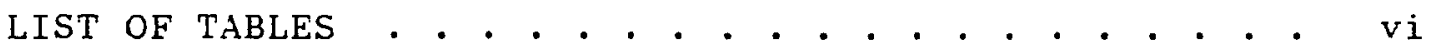

LIST OF FIGURES • . . . . . . . . . . . . . . . . . . . vii

\section{CHAPTER}

I INTRODUCTION TO THE STUDY . . . . . . . . . . 1

Background . . . . . . . . . . . . 4 4

Purpose of the Study . . . . . . . . . . 7

Importance of the Study . . . . . . . 9

Limitations of the Study . . . . . . 10

Outline of the Study... . . . . . . 11

II LITERATURE REVIEW . . . . . . . . . . . . . 12

Lack of Definition for the issistant

Principal's Role... . . . . . . 14

Lack of Training Frograms and Proposed

Solutions . . . . . . . . . . . . 22

The Importance of the Frinuipal in

On-the-Job Training Programs . . . 27

Summary . . . . . . . . . . . . 33

III RESEARCH METHODS . . . . . . . . . . . . 35

Research Design . . . . . . . . . 35

Sub.jects and Sampling . . . . . . . . 37

Instrumentation . . . . . . . . . . 38 


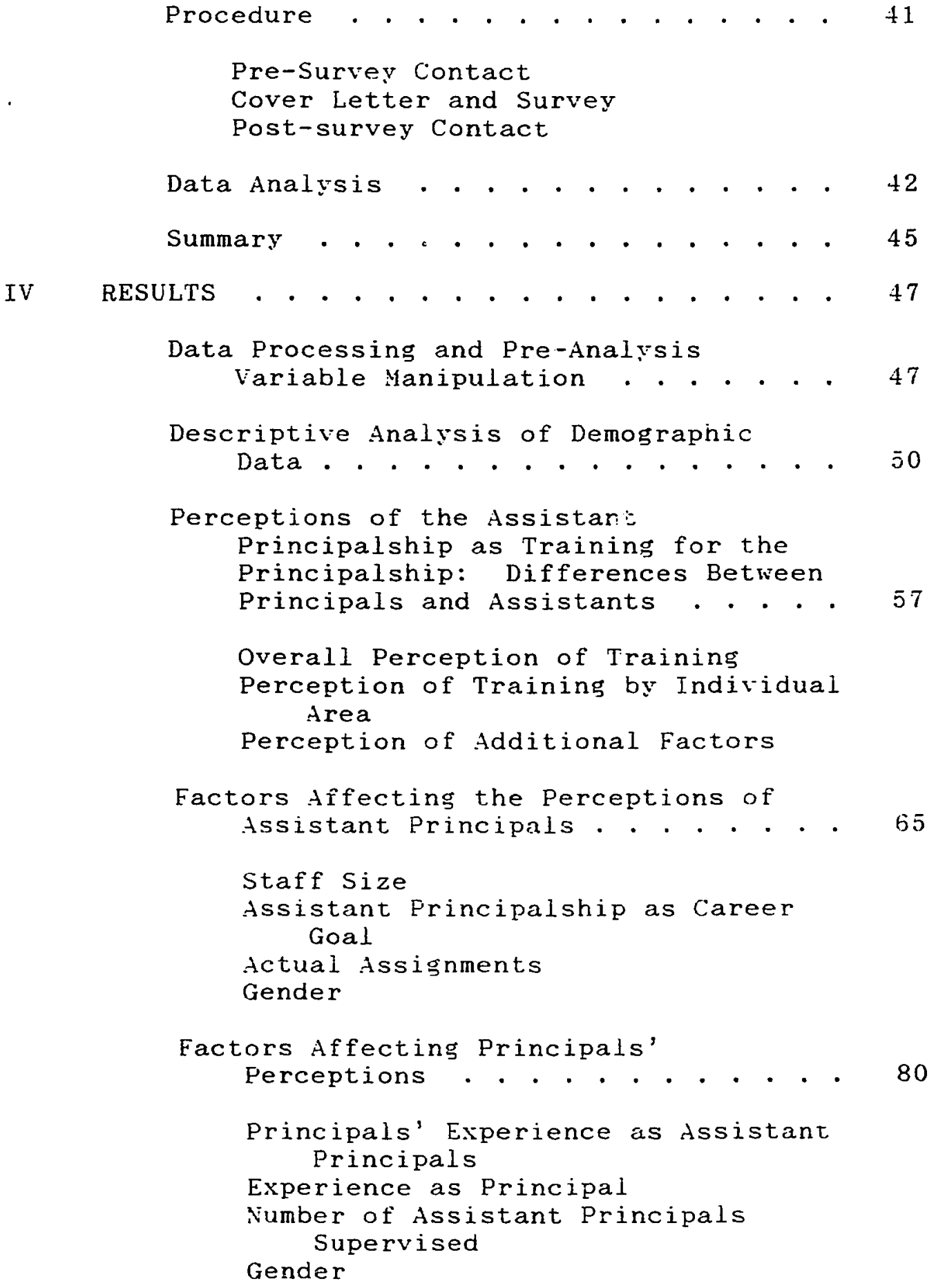




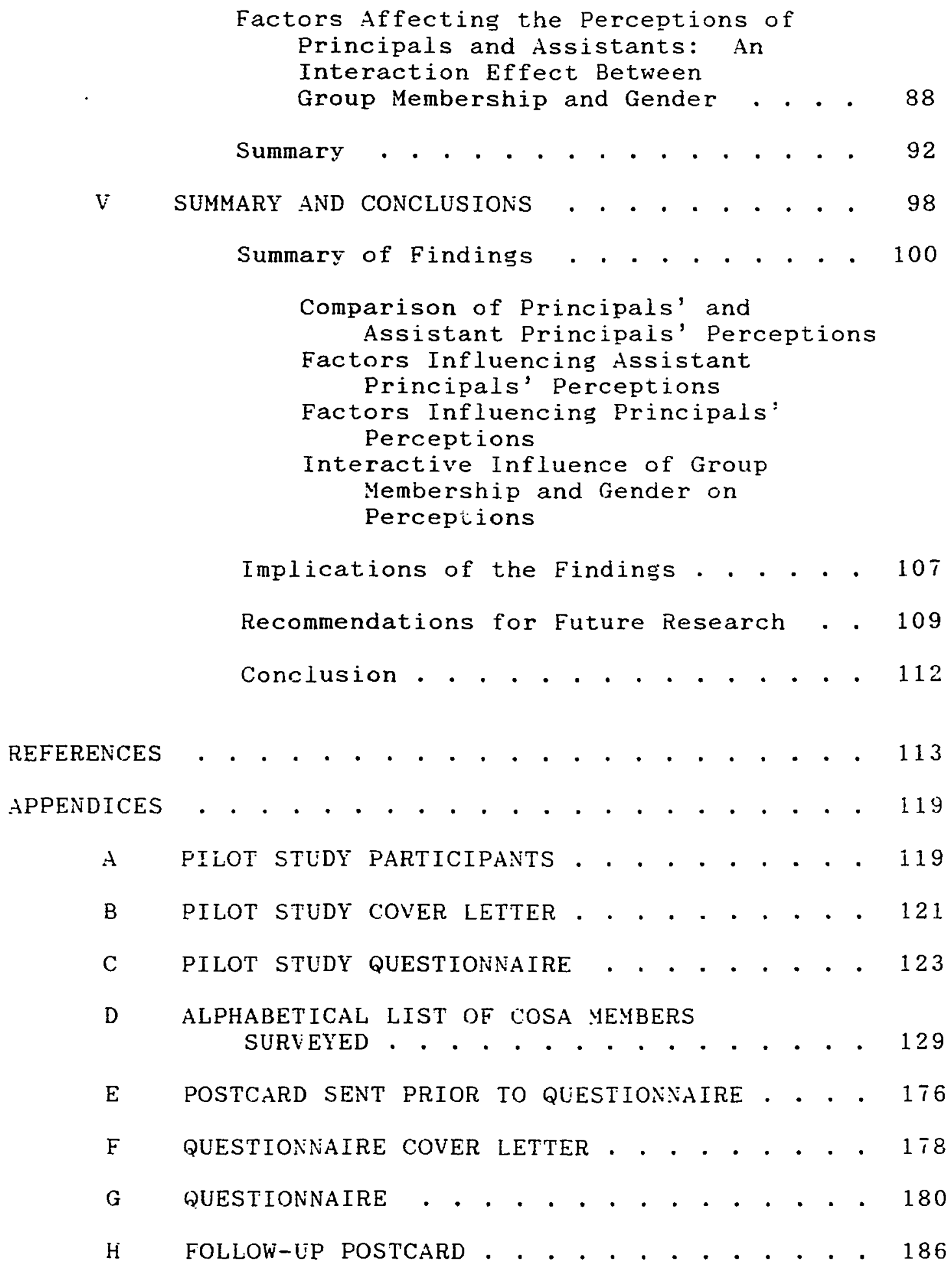




\section{LIST OF TABLES}

TABLE

PAGE

I Definitions for Assignment Abbreviations . . 55

II Comparison of Training-Value Ratings

With Assistant Principals' Actual

Assignments . . . . . . . . . . . . 12

III Gender and Assignment Areas . . . . . . . . i9

IV An Examination of the Interaction Between

Group Membership and Gender on the

Perception of Training Value ising

Analysis of Variance . . . . . . . . 91 


\section{LIST OF FIGURES}

FIGURE

PAGE

1. Demographic Information . . . . . . . . 51

2. Comparison of Principal and Assistant

Principal Daily Responsibilities . . . 56

3. Perceived Training Value of tssistant

Principal Position . . . . . . . . . 60

4. Comparative Importance of Assistant Principal

Duties . . . . . . . . . . . . 62

5. Differences in Perceived Value of Training

in Small vs. Large Staffs . . . . . . 67

6. Assistant Principal Assignments in Schools

with Smail vs. Large Staffs... . . . . 69

$i$. Comparison of Assistant Principai Perceptions with Assignments . . . . . . . . . . 14

8. Perceived Differences in the Value of

Training Index Items . . . . . . . . . iT

9. Differences in the Assignments of Yale and

Female Assistant Principals . . . . . . 81

10. Effect of Experience as Assistant Principal

on Principals' Perceptions of

Training . . . . . . . . . . . . . . . 
11. Effect of Experience as Principal on Principals' Perceptions of Training . . . . . . . . . . . 85

12. Effect of Staff Size on Principals' Perceptions of Training . . . . . . . 87

13. Perceived Differences in the Value of Training Index Items . . . . . . . . .

14. Comparison of Mean Training Scores for Male and Femaie Assistants and Principals . . . . . . . . . . . .

15. Differences in Perceptions of Training By Male Assistants and Principals . . . 94 16. Differences in Perceptions of Training By Female Assistants and Principals . . . 95 
AN ABSTRACT OE THE DISSERTATION OF Patricia Ann HoweIl for the Doctor of Education in Educational Leadership presented April 24,1989

Title: A Comparison of Assistant Principal and Principal Perceptions of the Assistant Principalship as a Training Ground in the Secondary School

APPROVED BY MEMBERS OF THE DISSERTATION COMMTTEE:

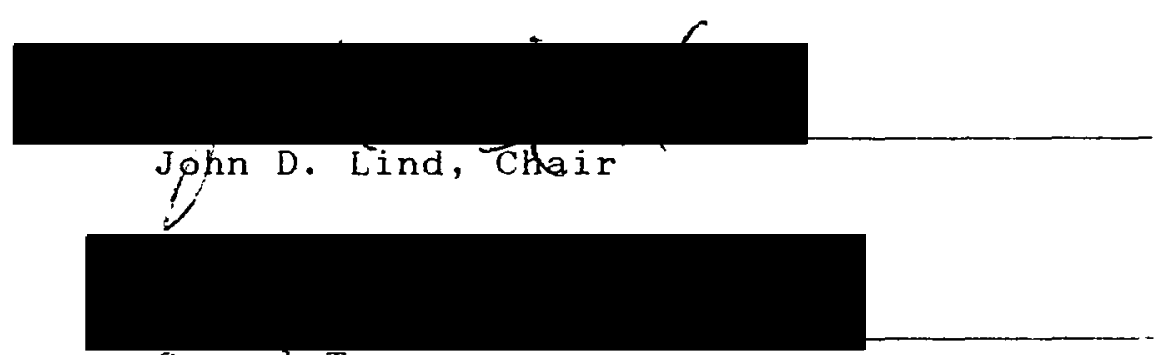

Carrol Tama

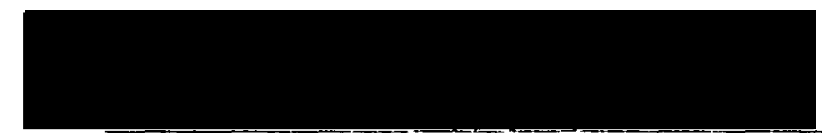

Carol Peterman

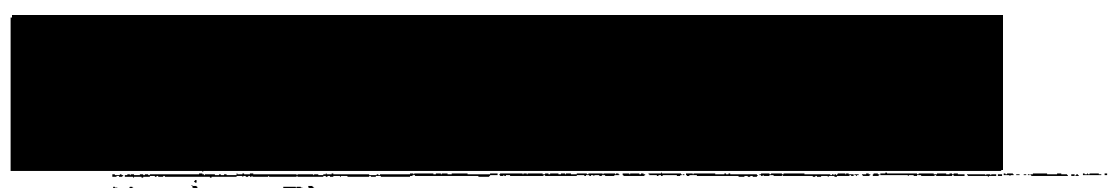

Maxine Thomas

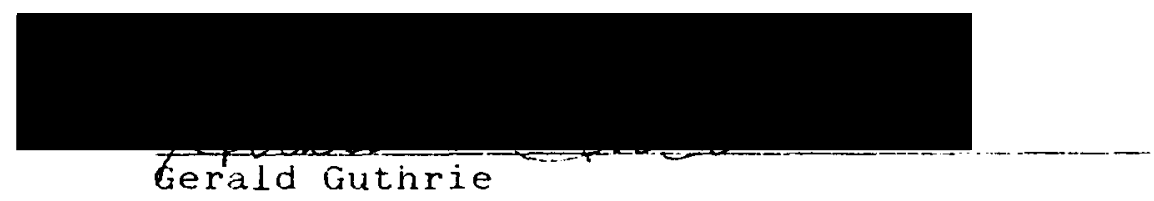

Although the assistant principalship has been ar important part of American secondary schools for cver thirty years, the educational establishment has vet to arrire at a 
formal definition of the assistant principal's role in that institution. Researchers have tended to find the assistant in a role defined by procedures. At the same time, the have called for a new definition of the assistant based on policy-making activities. This outcome has had several important consequences, not the least of which has been failure to provide formal guidelines for training assistants in their role and preparing them for future administrative assignments.

This study has investigated the relationship between fourteen areas of responsibility connected with secondary school administration and the role of the assistant principal in meeting these responsibilities. Unlike previous studies, it has emphasized, not the areas themselves, but the perceptions of principals and assistants who rated the value of each area as a training ground for the principalship. By classifying the areas perceived to be most valuable for training, the study contributes to the emerging definition of the assistant principalship. Also, by explaining the relationship between the administrators' backgrounds and their influence on the ratings given, this study has attempted to account for the factors that affected the respondents' perceptions.

The study was organized around three research questions: (1) Do principals and assistant principals differ in the extent to which they perceive the assistant 
principalship as an adequate training ground for the principalship? (2) What factors affect the perceptions of assistant principals? (3) What factors influence the perceptions of principals?

In order to address these questions, secondary school administrators who were members of the Confederation of Oregon School Administrators (COSA) were surveyed. They rated fourteen areas of responsibility for their training value and for the extent to which assignments to the areas were made on the basis of gender stereotyping. In addition, the areas to which the respondents were currently assigned were reported. The respondents also supplied background information concerning the years of experience in their current position and size of the administrative staff of which they were a part. Of the 454 members surveyed, 373 returned completed questionnaires, yielding a response rate of $71 \%$. Assistant principals comprised $57 \%$ of the sample, while principals comprised $43 \%$. Females comprised $16 \%$ of the sample and males $84 \%$.

Major findings suggest that while principals and assistants differed in the amount of value they awarded each area of responsibility, they consistently identified the same areas as valuable. Assistants' perceptions were found to be influenced by staff size and gender. Principals' perceptions were related to their length of tenure as 
assistant principals, how long they had been principals, number of assistant principals they supervised, and gender. These findings have implications for the future definition of the assistant principalship and improved training for assistants because they showed that principals believed in the value of the assistant principalship as a training ground. Thus, they also suggested the feasibility of combining the leadership of the principal and the concept of teamwork in both the definition and training of assistants. 


\title{
CHAPTER I
}

\author{
INTRODUCTION TO THE STUDY
}

Even though expanding student populations dictated more widespread use of the assistant principal in secondary school administrations nearly 30 years ago lGillespie, 1961), the role of the assistant principal has remained poorly defined. An important consequence of the failure to define the assistant principal's role has been the inability to provide its occupants with a well outlined program of training. A second consequence of a poorly understood role for the assistant principal is that new administrators may lack preparation to move into higher administrative positions. This study adopts the position that progress toward filling these needs can come, in part, from a better understanding of how both principals and their assistants view the role of the assistant principal and its place in the preparation of future administrators.

In their attempts to broaden understanding of the assistant principal's role, a number of educational researchers have begun to rely on two themes that have emerged from the educational literature. The first focuses on methodology, i.e., on the requirements of running the secondary school and its consequences for a new definition 
of the assistant principal's role. The second theme stresses the assistant principalship as a training ground in its own right and the role of the principal in shaping this training ground.

The first theme is methodological and advocates investigations which survey secondary school administrators. These investigations stress the importance of the administrators' first-hand knowledge in shaping the definition of the assistant principal's role. Smith (1984) exemplifies this methodology. He surveyed assistant principals, principals, and directors of secondary education in Washington. MacDonald (1981), Austin and Brown (1970), and Reed (1984) also conducted investigations which adopted this emphasis.

The second theme to emerge from the literature over the past fifteen years concerns the need to acknowledge the usefulness of the assistant principalship as a training ground and to emphasize the role of the principal in shaping it. Many remedies have been proposed to improve the kind of preparation assistant principals receive before they assume higher administrative positions (cf., Peterson, Yarshall, \& Grier, 1987; Howley, 1985; Hess, 1985; Bilbao, 1980). But it is only as researchers have turned to investigating the view of secondary school administrators themselves that the value of the assistant principalship as on-the-job training has been fully recognized. However, once recognized, seeing 
the value of the principal in shaping the training ground was a short step away. Kelly (1987) recommended that school districts explicitly regard the assistant principalship as a training ground for the principalship. Hall and Guzman (1984) maintained that the principal was the main facilitator for creative change and demonstrated how the principal's role affected the definition of the assistant principal.

In combination these two themes suggest the usefulness of assessing how each administrator, the assistant and the principal, places value on the various resporsibilities of the assistant principalship when they are viewed as a training ground. This study pursues that objective by surveying secondary school administrators.

The survey asked respondents to provide ratings of the areas of responsibility routinely assigned to assistant principals. The purpose of the ratings was to identify the areas which were perceived most valuable in preparing assistants to assume the principalship and other administrative positions.

The study made an assessment of the factors which influenced the administrators' perceptions, and broke new ground in this area. While it was hypothesized that background factors influenced the administrators' perceptions, there was a roid in the literature to suggest what those factors might be. Thus, this study explored a 
set of straightforward possibilities based on the experience of the researcher.

Factors influencing the perceptions of principals and assistants were hypothesized to emanate from the same sources. Problems affecting day-to-day life in the secondary school may involve such facts of school iffe as the size of the administrative staff, past experience as an administrator (either at the assistant or principal level) and, therefore, the qualifications to handle problems. Additionally, since women have more recently joined the ranks of administrators in larger numbers than in the past, gender may also influence the respondents' perceptions of the assistant principalship.

When the administrators' perceptions of the training value of indiridual areas of responsibility were combined with the factors which influenced their beliefs abolit the value of training, a definition of the assistant principal's role emerged which was consistent with the literature and contributed a better understanding of how these respondents arrived at their view.

\section{BACKGROUND}

The job of running a school, especially a high school, is a complex one and often too demanding for a single administrator. This observation is especially true as student populations grow. As the number of students 
increases, the number of problems to be solved also increases. This growth increases not only the number of student-related problems requiring attention, but those related to instruction, maintenance, evaluation, etc. increase as well.

Researchers (e.g., Greenfield, 1985; helly, 1987 ; Gorton, 1987; Jarrett, 1985) and administrators alike are beginning to recognize that the assistant principal should become a more integral part of the administrative team and make significant contributions to the school's performance and growth. Yet they have failed to define precisely what the role of the assistant principal should be. For example, Norton and Kreikard (1987) concluded that "in spite of this acknowledged importance of the assistant principal . . the position had been a forgotten step-child so far as administrative study and research were concerned" ( $p .23$ ).

In spite of this recognition, school districts continue to underutilize the interests and talents of the assistant principal with the consequence that they remain unprepared to assume higher administrative posts. While researchers blame the underutilization and training of the assistant principal on the educational establishment's failure to provide an adequate definition for the assistant's role (Austin \& Brown, 1970; Novak, 1963; Gatti \& Gatti, 1975 ), a number of attempts to define the role have bogged down. 
The attempts to define the assistant principal's role have been hampered by the nature of the position. The requirements of daily management in the secondary school inhibit the assistant principals' involvement in the kinds of tasks that lend themselves to professional growth. Empirical investigations of daily life in the secondary school (Smith, 1984; MacDonald, 1981; Austin \& Brown, 1970) observed the assistant principal largely absorbed in procedural tasks such as activity supervision or maintenance. At the same time investigators have also identified a need for greater participation in policy making in the assistant's day-to-day life (Greenham, 1972; Smith, 1984; Greenfield, 1985). Thus attempts to define the role of the assisiant principal have evolved around differences in the extent to which the assistants' time is exclusively devoted to policy or procedure.

A consequence of the failure to formaily define the assistant principal's role has been an ensuing failure to define what constitutes an adequate training program for the assistant principal. A number of remedies have been proposed to close the training gap--special academies, graduate education, internships, improved in-service, etc. However, only a few have begun to focus on the job itself as a training ground (in particular, see kelly, 1987) and to utilize the perceptions of administrators who hold the job 
in building a new definition for the assistant principaiship (Smith, 1984 ).

. One approach to better role definition and training is focused on the role of the principal as team leader and trainer (Gorton, 1987; Jarrett, 1985; Valentine, 1980; First \& Carr, 1986; Evans, 19861. These researchers have expressed the view that if the position of the assistant principal is to improve, it will require enlightened and dedicated leadership by principals. They claim that principals who provide active and creative leadership within a team management framework are fostering a better training ground for assistant principals and the development of their potential. Yet the same investigators suggested that most principals had not defined the role of the assistant principal, nor had they determined their own role in training the assistant principai for a principalship. Thus, an investigation which polls assistant principals for their perceptions of their role and its place in shaping their training needs to include principals as well.

\section{PURPOSE OF THE STUDY}

The purpose of this study is to compare the perceptions of principals and assistant principals with regard to the value of the assistant principalship as a training ground. Fourteen areas of responsibility 
identified by observing the day-to-day activities of assistant principais will be rated for their value as components in the assistant principals' training. The perceptions of principals and assistants will also be compared to learn what specific areas of responsibility each group of administrators believes to be most valuable in the training of assistants for future administrative assignments, in particular the principalship. Factors affecting the respondents, perceptions will also be explored.

In order to address these issues, the study poses three research questions:

1. Do principals and assistant principals differ in the extent to which the perceive the assistant principalship as an adequate training ground for the principalship?

2. What factors affect the perceptions of assistant principals?

3. What factors influence the perceptions of principals?

The answers to these questions will emerge from the statistical analysis of survey data. This information can then be incorporated into the refinement of the definition of the assistant principal's role, the molding of the assistant principalship into an improved training ground, 
and a more clear understanding of the role of the principal in the process.

\section{IMPORTANCE OF THE STUDY}

This research explored a refined definition for the assistant principal's role by comparing the perceptions of assistants and principals. In particular it examined the value of the assistant principalship as a training ground and sought to identify the areas of daily responsibility most ralued by secondary school administrators for their training. In addition, the study also sought to identify factors influencing the respondents' perceptions.

The study extends the body of current research and stands apart from oarlier investigations in several ways. First, it has added to the body of research that relies on data generated by the expertise and authoricy of practicing administrators. Second, from statistical evidence based on this data, it argued for a new definition of the assistant's role based on a combination of procedural and policy-making responsibilities. Third, the study was based on a comparative analysis of administrators' perceptions, those offered by assistants and principals. Fourth, it assessed factors that influenced those perceptions. Thus, the study captured both points of view in formulating its recommendations for new perspectives. 
Given the problems of declining enrollment and diminushing financial resources for many school districts. ferer assistant pincipals may want to enter the system ard fever will adrance. The pool from which principajs and contral office administrators wili ultimately be selected wi i be smaljer, since the numbers moring in and out of ti... cntry-level positions will decrease over time. This implies that tine inportance of training and preparation for entellevel administrators is more rital and at the same time morc. in dangcr of being ignored. This study and others aftor which it has been pat terned may contribute remedies that will offect the adverse effects of this growing problen.

\section{LTMITATONS OF THE STUIY}

The result of thjs studs may be i imited by the following factors.

1. The surtey instrument used has a mailed questionnaire and the researcher has unable to predict the number of returned questionnaires.

2. The data were self-reported and although perceptions might have been strongly indicated they might not have always reflected the true picture.

3. The findings were subject to the limitations of surveying one professional organization. 
4. This was the first survey of this nature to this particular professional group, therefore, there was no previous data with which to make a comparison.

$$
\text { OUTLINE OF THE STUDY }
$$

The recognition that the assistant principal's role was, in Hess's (1985) words, "haphazardly" defined was slow to appear, and its consequences for training have only begun to be realized. The documentation of this process, along with some of the remedies currently being proposed, are presented in chapter II.

This study analyzed responses to a mailed survey to address the research questions it proposed. Chapter III describes the research design, methodology, subject selection, survey design, procedure, and statistical analysis.

Statistical results are presented in chapter IY, while Chapter $V$ summarizes the study, describes implications of the findings, and makes recommendations for future research. 
CHAPTER II

\section{LITERATURE REVIEW}

Since the future success of American secondary education in part depends on the grooming of new administrators, it is reasonable to assume that the role of the assistant principal is well understood by the educational establishment. This is not the case, however. Even though expanding student populations dictated more widespread use of the assistant principal in secondary school administrations nearly 30 years ago lGillespie, 1961), the role of the assistant principal has remained poorly defined. Is recently as 1985 , Hess roiced the complaint that the position of assistant principal evolved in a haphazard manner without systematic planning and still remains without any general objective or design.

- An important consequence of the failure to define the assistant principal's role is the inability to provide its occupants with a well outlined program of training. Formal education for administrators in most states is poorly specified and usually consists of little more than 30 hours of post-baccalaureate work that focuses on diffuse topics and has no central philosophy or core. There are no national licensing agencies for federal educational 
organizations that are charged with educational quality control, curricula content, or the evaluation of course content (Guthrie and Reed, 1986). Nor, is there an accreditation system for school administration programs.

A second consequence of a poorly understood role for the assistant principal is that new administrators mav lack preparation to move into higher administrative positions. It remains unclear whether or not the jobs currenty performed by assistant principals prepare them for growth or merely allow them to assist in the day-to-day management of the school.

This study adopts the position that progress toward filling these needs can come in part from a better understanding of how both principals and their assistants view the role of the assistant principal and its place in the preparation of future administrators. This chapter reviews the literature that identifies these problems and out of wich the need for this study was formulated. It should be noted, however, that there ias no information abailable in the literature review that addressed the area of gender and how it might influence the role of the assistant principalship. The sections that follow discuss the lack of role definition and the lack of training programs along with the solutions that have been proposed to fill the gap. 
LACK OF DEFINITION FOR THE ASSISTANT PRINCIPAL'S ROLE

A complete definition of the assistant principai's job that would be universally accepted in the field of education has been slow to develop. The variety of jobs performed by assistant principals do not add up to a cohesive job description. According to Austin and Brown (1970)" . . . [For] most people in secondary schools the assistant principal occupied a position which was not well labeled by titling it 'assistant to' anyone or anything" (p. 23 ). lovak (1963) also characterized the assistant principalship as "vaguely defined" (p. 19) and stressed the need for more clarity and specificity in descriptions and definitions of not only the assistant principal's role, but his/her status, functions, and duties.

In a study by lorton and Freikard (198i), 81 percent of the principals from schools of more than 500 pupils reported that they had an assistant principal. While this statistic suggests assistant principals are present in a large majority of schools, little has been done to broaden understanding of the assistant principal's administrative role. Norton and Kreikard concluded that "in spite of this acknowledged importance of the assistant principal...the position had been a forgotten step-child so far as administrative study and research were concerned" ( $p .23)$. 
Gatti and Gatti's (1975) description of the assistant principalship also emphasized the vagueness of the position and the tendency for the assistant principal's role to fluctuate in the course of the school day depending on the kind of activity in progress.

The vice-principal was part of the administration and was not a part of the teaching staff while carrying out his or her administrative functions. He or she was considered an employee and not an officer of the school board. The vice-principal reported directly to the principal and rias generally in charge of specific areas such as student discipline. The vice-principal sas liable for his or her own acts, but not the acts of teachers unless the rice-principal knew or shouid have known of the potential conduct (p. 301 ).

Although it has become clear that a precise definition for the assistant principal's role is required, attempts to fill the requirement have been hampered by the nature of the position. A natural tension exists between long and short term requirements. issistant principais need to prepare to move into higher administration to beneit the system as a whole over the long term. However, the short term requirements of daily management in the secondary school inhibit their involvement in the kinds of tasks that lend themselves to professional growth.

As a result, two competing concepts to characterize the role of assistant principals have arisen. Roughly speaking the concepts can be compared to the distinction between policies and procedures. On the one hand, growth as 
an administrator is enhanced by participation in activities dedicated to policy setting. On the other, day-to-day management activities dictate that the assistant principal administer ongoing procedures. Many examples in the literature demonstrate the inadequacy of either concept to define the assistant's role.

Several researchers have implied the desirability of a policy setting. role for the assistant principal. For example, Greenham (1972) contended that the position of assistant principal was often too heavily weighted in the direction of para-professionai tasks, duties that must be performed for the school to function, but that did not necessarily promote professional growth for the assistant principal. Similarly, Smith $(1984)$ in a survey of assistant principals, principals, directors of secondary education, and district superintendents in liashington, concluded that While the respondents to the study were in generai agreement concerning what secondary assistant principals were currently doing, they believed they should be cioing something else. Smith reported that respondents viewed assistant principals as educational leaders and that they should be encouraged to participate more in tasks of a curricular and instructional nature.

Greenfield (1985) suggested the role of the assistant principal as it is presently conceived is not particularl: attractive and that limiting its functions to monitoring 
student behavior, maintenance, and organizational stability robs both teachers and school principals of a potentially vital instructional resource. He concluded that the use of assistant principals in instructional and organizational matters could result in a more effective use of the administrative resources available to schools without sacrificing the student supervision and scheduling functions that needed to be addressed.

While investigators such as Greenham, Smith, and Greenfield were in pursuit of the policy setting definition for the assistant principal, the empirical worl of other investigators was demonstrating that on a day-to-day basis the procedural assistant principal was more often found in practice. From their work (Fallon, 197t; Brown d Rentaschler, 1975; Black, 1980; Austin and Brown, 1970; Reed, 1984; Bates and Shank, 1983; Veidy, 1979; McDonald. 1981; Hentges, 1976; and Paus, i970) a common theme emerses concerning the typical duties that define the assistant principal: the prominence of pupil personnel functions. Fallon (1974) stated that, "As assistant principal, there are two areas of prime responsibility that wouid either make or break an administrator. These are attendance and school discipline" (p. $\quad i T$ ). In determining the five duties most frequently assigned to Indiana assistant principals, Brown and Rentaschler (1975) found, as Austin and Brown (1970) had, that pupil personnel activities were usually a prime 
focus for the assistant principal. Reed's (1984) field study of eight large Southern California high schools found that most of the assistant principals studied dealt with student discipline, with the assistant principals being responsible for the methods by which they dealt with student misconduct. Bates and Shank (1983) stated that when students, parents, or assistant principals themselves were asked to describe the job of the assistant principal, a common response was "discipline, attendance, and supervision of student activities" (p. 111). School administrators, even assistant principals, commonly described the job as a necessary but unrewarding step on the career ladder. Administrators concluded that such a role was not good for the individual of the school.

Black (1980) characterizes this observation as a consequence of the position development. She reports that the assistant princigalship was established primarily to handle clerical duties, and has never evolved into a solid job description. Consequently, the secondary assistant principal lacks a level of importance in the school's administration. In addition, Black found that high levels of frustration are associated with the lack of time necessary for assistant principais to complete all the tasks for which they become responsible in the course of the giren day. 
Black further suggested that the role of the secondary school principal needed to be changed to grow with any job description currentiy being used, or else the job description should be changed to comply with the present role. Ranyako and Rorie (1987) felt the modern assistant principal must first be thought of as a principal, and oni secondarily as a deputy to the principal.

Black (1980) stated that it is possible for the ordinary assistant principal to go for weeks or even months buried in custodial, clerical, disciplinary, and social duties, to the total exclusion of meaningful interaction with teachers and students in the classroom setting. Weldy (1979) called this the "Busy Person Syndrome" (p. 20), which he defined as the school administrator who was never able to see the best students and teachers in the school. The findings of McDonald (1981) dramatized Black's point. In a study of the rorkday or the urban ingh scrocl assistant principal, McDonald discovered that on the average the assistant principal spent 48 percent of his/her workday in meetings, both scheduled and unscheduled. She also observed that 17 percent of the day was spent at desk work, 4 percent on phone calls, and the remaining 34 percent in observational and informational tours.

The problems associated with the "Eusy Person Syndrome" are exacerbated by the fact that the assistant principal is given little responsibility. Austin and Brown 
$(1970)$, in one of the more extensive studies made of the assistant principalship, discovered that the assistant principal was often the person who kept the school running. They surveyed secondary school administrators and found that while the assistant principals were "senerally caught up in practically all aspects of the administrative processes or their school" ( p. 34), they were given little responsibility. While the level of responsibility varied from situation to situation, it was rareiy absolute. It was more Iikely to be "slight" or "sharea" (p. 46$)$.

Both Hentges $(1976)$ and Faus $(1980)$ had findings similar to those of Austin and Brown (1970). A study conducted by Hentges (1976) in yinnesota found that while assistant principals were involved in nearly all administrative processes, they nere often not allowed total responsibility for a task. The only area in wich the assistant frincipai was perceived as having a high levei of authority was once again in the role of student disciplinarian. The bulk of the assistant principal's activities were in curriculum, and instructional tasis, staff personnel activities and pupil personnel. This point was also driven home by Paus in a surver of junior and senior high schools in oregon. Paus (1980) found that assistant principais were deiegated a wide variety of primary responsibilities, but that there was little consistency in the tasks assigned. 
In short, the assistant principal spends much time in the execution of pupil personnel activities, but has assigned to him or her no clear and consistent set of responsibilities. This observation lead Austin and Brown (1970) to a definition consistent with the procedures definition of an assistant principal. They concluded that the assistant principal was an intermediary who was essential to the school's ability to function, but who had no consistent set of responsibilities except that of supervision of the school in the absence of the principal.

t more recently identified difficulty associated with the procedures definition of the assistant principal is job dissatisfaction. Assistant principal job dissatisfaction seems to stem from the more routine and clerical tasks: maintenance, student photos, attendance, transportation and testing. Black's (1980) survey, conducted in yaryiand, revealed that for $\$ 6$ percent of those wno responded, the best-liked job areas were related to the instructional program. Discipine-reiated tasks were least liked by 83 percent. This gives credence to Greenfield's 11985 i argument that assistant principal responsibilities be extended to instructional and orsanizational areas.

Kalla $11983 i$ surveyed secondary school assistant principals in hentucky and discovered that, while assistant principals were senerally satisfied with their positions, there was a low positive correiation between job 
satisfaction and the assistant principal's perceptions of responsibility and job importance. In this study, the type and importance of the job assigned influenced the perceived satisfaction of the assistant principal. Thus, Kalla's findings suggested that change in the level of responsibility and job importance could enhance the assistants' perception of job satisfaction.

\section{LACK OF TRAINING PROGRAMS AND PROPOSED SOLUTIUNS}

Pernaps the most important consequence of education:s inability to arrive at a consistent definition for the assistant principal's role has been the subsequent inability to derive a training program for the position. This section identifies the lack of specifications for training and describes some of the remedies identified in the literature for converting the assistant principal's day-to-day experience into a training sround for later administrative positions, in particular the principalship.

For the most part, the training which could provide assistant principals with the opportunity to enhance their professional growth has been ignored. The in-service needs of assistant principais are rarely addressed, which atfords them few chances to develop aspects of their profession outside of the school environment. The literature lGutinrie and Reed, 1986) indicates that more training needs to be available that is specifically designed to meet the needs 
for professional growth of the assistant principal. This lack of training may be one reason that assistant principais sometimes express dissatisfaction with their jobs and frustration with the lack of potential for career growth.

Kolb (1984) stated that considerable improvement could be made in the experiential learnins of administrators, as this type of learning was crucial to the uitimate acquisition of skills and knowledge. Thriving programs could improve the professional growth capabilities of their administrators by emphasizing the possibilities of learning from experience. According to Peterson (1985), additional training, socialization, and support would make for more effective administrators. Through the conscious efforts of those involved in the preparation, training, and development of assistant principals, substantial changes could occur in the overall quaitity of school administrators.

$\therefore$ number of remedies have been proposed to eliminace this deficit. Many of them adopt Fell: : 1987 । recommendation that school districts regard the assistant principalship as a training ground for the principalship.

A f requently proposed remedr has been an assistant principal academy. According to Peterson, Marsiail, and Grier (1987), an assistant principals: academy couid provide some of the formal training and on-the-job soclaization necessary for professional srowth. The purpose of the academies would be to give assistant principals the 
opportunity to work with teachers, central office administrators, and incumbent assistant principals before their administrative roles are crystallized and while they are open to innovative ways of filling administrative positions. The academies couid assist in the professional development of administrators by providing ongoing support and the opportunity to address the deficiencies and needs identified by the participants. The authors concluded that assistant principal academies could be effective ways of giving technical training and promoting a shared culture among school districts while increasing the pool of qualified administrators. The enterprises involve certain costs and risks, but the potential they have for reshaping the administrative workforce is considered substantial and well worth the effort and challenge.

$d$ second type of remedy involves the use of continuing education at the graduate ievel. Howley (1985) made specific recommendations for the professional development of assistant principals in curriculum strategy, change, and awareness. The author also recommended that the assistant principal should rotate duties with the principal in order to avoid "job burnout" and the assistant principal should remain active in the classroom in order to maintain a perspective on school functions.

Still a third remedy has been the utilization of internships. Hess (1985) suggested that, at the university 
classroom level, future assistant principals should undertake internships in order to develop an understanding of operations management. An internship should be structured around objectives that relate to the professional fuifillment and development of the individuai who undertakes it.

An improved in-service training program for the assistant principals has also been recommended. In Southern Idaho, Bilbao (1980) conducted a study to identify the inservice needs of secondary assistant principals. The study tound a significant difference in the ratings made by assistant principals and principals regarding the needs of the community and staff personnel. Critical in-service needs were discovered in all areas surveyed. Principals agreed with all other in-service needs voiced by assistant principals except in the areas of curriculum and instruction, where assistant principals expressed a need for better in-service design. Bilbao recommended that assistant principals be appraised of the study's findings in order to increase their own understanding of common needs. Similarly, the results should be communicated to district and state educational administrators and organizations with the intent of developing local and regional programs designed to meet the in-service needs of assistant principals. Assistant Erincipals were also encouraged to seek the leave and financial support necessary to 
participate in national and regional programs and workshops which addressed their professionai growth. This observation has suggested to many investisators that the role of the principal in the development of these programs deserves further research.

Still another remedy is based on London's (1985) recommendation that organizes a training program around the assistant principal's tenure in his/her job. London identified three stages of socialization of the assistant principal. The kinds of support, feedback, and discussions or organizational mission and goais present in the first stage (the first vear) of socialization werc augmented by the personal ties a new assistant principal developed to the organization. During the second stage of development (the second through fourth yearsi, new administrators needed to develop a sense of achievement and be acknowledged for the importance of their contribution. In the third stage of socialization (the fifth year and beyond), administrators needed continual reinforcement of their effectiveness within the organization and ongoing contact with other administrators. During this period, the norms and values established during the early years must be maintained and reinforced by superiors.

Peterson (1985) felt that incomplete or inappropriate socialization of assistant principals could occur if any of these stages were not properly developed. At no point 
during the process could assistant principals be seen as totally on their own, separated and isolated in their schools. Ties to the district mission and to the broader concerns of the school system needed to be built, naintained, and adjusted to changing situations. Without ongcing soujalizatiun, administrative effectiveness mish falter.

A common thread throughout all the remedics is trainiug on the job. Academics, internships, and in particular, in-service emphasize the potential for trainins specifications to arise in practice.

THE IMPOHTANCE OF THE PRINCIPAI. IN ON-THE-JOR TRAINING FROGRAMS

Most researchers placed primary responsibility for developing an on-the-job trainins program for the assistant principal at the doorstep of the principal. Many have cxpressed the view that if the position of the assistant principal is to improve, jt will require enlightened and dedicated leadership by principals (e.g. Gorton, 1987 ; liovak, 1963; kelly, 1987; Jarrett, 1985; Austin and Brown, 1979 ; Valentine, 1980; Manasse, 1982; First and Carr, 1986; and Evans, 1986).

An assistant principal's future growth and success seem largely to depend upon the extent to which principals share administrative responsibilities and take an active 
role in preparing assistant principals for advancement. Principals who provide active and creative leadership within a team management framework are seemingly fostering a better training ground for assistant principals and the development of their fotential. Fet, these investigators suggested that most principals had not defined the role of the assistant principal, nor had they determined their own role in training the assistant principal for a principalship.

Gorton (198T) found that most assistant principals wanted more responsibility--and were qualified to take on such responsibility--in the areas of curriculum improvement, advising parents' groups, public relations, and the school budget. He concluded that "the key person to maximize the assistant principal's contribution was the school principal" (p. 2). No other individual worked more closely with the assistant principal, and no other persor was more important to his or her professional success. Gorton stated that the principal could help the assistant by expanding the demand of the assistant principal's job, adrocating the job itself as well as the possibiitty for increased rewards, and facilitating professional growth.

Novak (1963) expressed the concern felt by many about relations between principal and assistant principal:

It is necessary for the principal and the vice principal to be able to operate comfortabiy within a mutually acceptable point of view that allows each his individuality and free expression of opinion, ret permits a reasonably united 
front. A vice principal who performs minor errands without latitude or auinority to make any decision on his own is not justified in his salary, loses self-respect, the position itself suffers, and he might lack assurance and creativity if he ever should emerge from the shadow of the principai (p. 20).

Kelly ( 1987$)$ concured with the findings of Gorton and Kovak. He concluded that the role of the assistant principal was defined and shaped largely by the principal, with only a philosophical foundation provided by the superintendent and school board. While the school districts identified instructional leadersip as the major aspect of the principalship, and the assistant principalship as the training ground for that position, assistant principals here not involved in the instructional leadership responsibilities of the administration. helly recommencied that "school districts explicitly regard the assistant principalship as a training ground for the principaiship. (p. 18). The validit: of this position depended aimost entirely on the principal.

In short, a number of investigators have demonstraced the importance of the principal in converting the assistant principalship into a training zround. Jarrett's 1985 ; findgings echo the work of many others who recommended that assistant principals should have a more active roie in the supervision of departments. Tet evidence exists wich suggests that principals frequertly fail to see the dilemna in this light. In their study, Austin and Brown (1970) 
found that "more principals than assistant principals have positive perceptions of the role the assistant principal plays in the school" (p. 47 ).

Other researchers have been more specific in their recommendations. The principal needs to function as a specific type of leader, not just one who makes assignments, in order to best train his or her assistants. They have also recommended that the most effective training method is the team management approach, with the principal acting as team leacier. For example, Valentine: 19801 stated that principals were typically overiooking their obligation to train assistant principals. Consequent 1 , Valentine recommended a team management system, wherein communication was encouraged among team members with the affect being that assistants couid learn more about the decision-making process. Each assistant principal would have assigned responsibilities, and his performance vould be assessed by the principal on a regular basis. The scam approach bould provide a framework for administrative soal setting and skills evaluation. Manasse (1982) ielt that effective principals were those who were able to expand the roles of lower-level administrators.

An important outcome of focusing on the principai may be the emergence of a new definition of the assistant principal's role. By reintroducing the concept of teamwori, a number of researchers have put assistant principals in a 
policy-implementing role. While they are still charged with many day-to-day activities, in this view they emergo as part of a team whose responsibility is implementing change. Research by First and Carr (1986) and Evans (1986) casts the principal in the role of a leader. First and Carr called these leaders "change masters" (p. 48 ), in that they created a rision of a possible future that allowed themselves and lower-level administrators to envision a new reaity for the organization and to aid in its translation into concrete terins. The roie ố the "change master" involved a departure from traditional patterns of management behavior. A "change master" must help his administration to understand that the environment is rich with information and full of opportunities for innovation. Evans concerned that the central task of school administration should be to develop and regulate the planning and decision-maing processes of the orsanization. Leaders are judged by the worth of their decision, and very simply, the rortin of a given decision is dircctly related to the degree in wich the goals of the organization are attained.

Hall and Guzman (1984) also maintained that the principal is the main facilitator for creative change and demonstrated how the principal's role affected the definition of the ussistant principal. In their study, when principals were passive, assistant principais maintained the status quo; when active principals involved assistant 
principais there tended to be a dynamic change-facilitating team .

Gross, Shapiro, and Heehan (1980) investigated the circumstances under which teamwork was most successful. They found two sets of circumstances. The first was that administrators had very few preconccived notions concerning the roles to be filled by the principals and the assistants. There was flexibility in role definition and a willingness to shift roles and responsibilities when necessary. The second circumstance was that administrators believed the entire team shouid be involred as much as possibic in the total management of the school, especially in areas where he or she exhibited a special taient. The autiors found the teamwork approach fostered an attitude of openness on the part of the administrator, which in turn helped other forms of communications within the school.

Rodrick 11986 also argued for a teamwor: type 0 approach. He asserted that the principal take the first steps to reassess and upgrade expectations for assistant principals. One of Rodrick's suggestions was to assign assistant principals as staff committee monitors who would attend committee meetings, support the chair's planning by previewing strategies before each meeting and review progress and events after, provide information and resources to the committee, and inform members of how their actirities affected the rest of the school. Another means of achieving 
statif interaction would be to assign assistints tib responsibility ror interviesing, hiring, and erallaring a portion of the staff. A third method wouid be co piace an assistant in charge of soiring an educational problem, lising interaction and input from the staff.

\section{SUMNARY}

Athough educational researchers have made numerous attempts to define the role of the assistant principal, they have met with littie success. Some investigators have attempted to define the assistant as an administrator involved primarily in policy setting. They have been largely contradicted by empirical investigations of the assistant principal's daily activities. These studies found assistants who wished to be involved with policy but. who were largely involved in procedural duties instead. They also reported that many assistant principals felt they had too little responsibility and they were experiencing some job dissit. isfaction.

Two important consequences emerge from the fiailure to reach a consensus on a definition for the role of the assistant principal. The first concerns training. Failure to define the assistant principal's role has led to a lack of specifications for training. Since no clear role has been defined, no curriculum has evolved that is designed to prepare new educators who aspire to move into administrative 
ranks. The second consequence is that over the long term, the system will have fewer well-prepared administrators than it requires.

A number of solutions have beer proposed by researchers to remediate this difficult:. Continuing education on the graduate level, internships, more in-depth in-service programs, among others, have been proposed and evaluated in the literature. Although no singie remedy promises to alleviate the problems described, tro themes run through this body of research and appear io nold promisc. The first focuses on new attempts to define the roie of the assistant principal in investigations of the iaily life of running the secondary school, i.e., in evaluating the potential of the assistant principal's position as a training ground. The rationale for this approach crows out of the idea that if the worth of the position as a raining sround can be identified, the identification ma :ord to a better definition of the assistant rrincifal's roie. The second theme stresses the role of the principal in shaping this training ground. In combination, the themes suggest the usefulness of assessing how each administrator, the assistant and the principal, views the assistanc principalship as a training ground. Such an investigation is the primary objective of this study. 
CHAPTER III

RESEARCH METHODS

The purpose of the study is to compare the perceptions of principals and assistant principals regarding the role of the assistant principalship as a training ground. This chapter describes the research methodology utilized to conduct the study. The sections below describe the research design, subject selection, instrumentation, procedure, and data analysis.

\section{RESEARCH DESIGN}

Previous research related to the development of administrative skills in the assistant principalship has most often invoired case studies, fieid studies, or on-site research methods. A review of literature revealed that previous research had largely involved the observation of a small group of administrators over a short period of time. The obvious limitation of this type of study was its failure to gather large amounts of data which would allow for indepth comparison and evaluation of those factors deemed most important for the assistant principal's administrative development. Therefore, in order to increase the amount of data available, it was desirable to study a large group of 
assistant principals and principals. Additionally, by involving a large number of study participants, the risk of misleading results was reduced and the reliability of findings was enhanced.

A mail survey was the most expedient method for obtaining a large data base. The survey made it possible to conduct a study which described not only the similarities and differences in administrators' perceptions, but aiso which assessed relationships between their perceptions and other factors that might have an iniluence.

Since no pre-existing survey instrument was avaijable in the literature, the researcher, with the assistance of other educational professionals, designed a surrer especially for the investigation. As described beiok, the survey was refined and its face validity evaluated during a pilot study. On completion of the pilot, survers were mailed to 454 principals and assistant principais at ine secondary level who were members of the confederation of Dregon School Administrators. Statistical analyses of the results focused on the research questions which addressed differences in principals' and assistant principals' perceptions of the worth of the assistant principalsinip as a training ground. 
SLBJECTS AND SAMPLING

In order to enhance the usefulness of the study, a sample of survey respondents was sought whose characteristics would be representative of the population of secondary school administrators throughout Oregon. Thus a group of individuals was required which would reflect this population as well as be accessible through the mail. The Confederation of Oregon School Administrators (COSA) was chosen for this purpose.

CosA is the leading professional organization of Oregon school administrators and claims a majority of administrators among its membership. Surveying the membership of this organization enhances the generalizability of study results because many different types of schools are served by them. Two school statistics, administrative staff size and student population, ittest to the variety of school types represented. Accoraing to Cosit statistics, administrative staff size varies from one to five, while student populations vary from 50 to 2,000 .

The organization is also recognized as a forum for growth and professional development for its membership. Through literature, conferences, and workshops the organization provides continuing education and srowth for its members and serres as a focal point for much of their professional activity. All administrators currently 
holding positions in the state of oregon are invited by the organization to join, and the membership currently numbers nearly 1,000

At the time the survey was administered, there were 454 COSA members who were secondary school administrators. Since mail surveys tend to be returned at a low rate, the decision was made to bypass sampling from the 454 members and mail surveys to all of them. The rationale for this decision was based on the idea that should the response rate fall as low as $50 \%$ or less, the number of surveys that couid be analyzed would still be high.

\section{INSTRUMENTATION}

Since no pre-existing questionnaire was available which addressed questions posed by the study, a surver was specially designed. The investigator used the review of Iiterature, a pilot study, and interriews with experts in the field to design the survey.

Development of the surver instrument took place in several steps. With the help of the literature review and expert consultation, a first draft of the survey instrument was prepared and then revised with input from a second panel of experts. This draft was then subjected to a pilot stuar. The pilot study was conducted in the Huntington Beach inion High School District of Orange Count Suggestions and input provided by pilot respondents were 
then used to modify the questionnaire. Several modifications were implemented as a result of the pilot. In particular, the survey was shortened somewhat in order to encourage the largest response rate possible. Content of the final survey is described in succeeding paragraphs, and a complete survey is provided in Appendix G.

A review of Iiterature (e.g., Guthrie \& Reed, 1986; Gutek, 1983; Knezevech, 1975; Bortner, 19721 uncovered fourteen areas of responsibility that were consistently associated with secondary school administration. They were: (1) discipline; (2) curriculum development; (3) budgetary process; (4) community relations; (5) teacher evaluation; (6) staff development; ( 7 ) maintenance; (8) athletic supervision; (9) activity supervision: $: 10$ ) schooi improvements; $(11)$ guidance and counseling; (12) hiring and selection: (13) special education: and $(1+)$ improvement of instruction. Since the research questions addressed the relationship between the fourteen areas and the respondents. perceptions of the assistant principalship as a training ground, the respondents' ratings of the areas in several different contexts formed the major portion of the survey.

The primary research question addressed the extent to which principals and assistants differed in their perceptions of the assistant principalsnip, as defined by the fourteen areas. Thus, the first section of the surver asked respondents to rate how much each area contributed to 
preparation for the principalship. Ratings were in the form of a six-point Likert scale with the following values: (0) not at all; (1) very little; (2) little; (3) somewhat; (4) very; (5) extremely. Since gender was believed to be a factor that would influence perceptions, respondents were also asked to rate the extent to which they believed each area of responsibility was subject to assignment stereotyping, i.e., to which assistant principals were more likely to be assigned because of their gender. The same six-point likert scale was used with these items. Finally, it was theorized that a comparison of respondents: perceptions of each area with actual performance in the area would shed light on the statistical results. Thus, each respondent was asked to indicate in a third section of the survey whether or not he/she was currently assigned duties in each of the fourteen areas.

Ten additional items queried respondents for their perceptions in more general areas of responsibility such as staff complaints and role clarification. Two jems in this series, whether or not respondents' believed the assistant principalship was a satisfactory career yoal in itself and whether in general they believed the assistant principalship prepared them for higher administrative positions, were focal points in the anaiysis described below.

The two remaining research questions addressed factors that might influence the perceptions of principals and 
assistants. It was hypothesized that these influences would be related to the respondents' experience in the field of education. Thus the survey contained demographic items related to the administrators' background, such as years of experience in the present position and the number of assistant principals on staff.

In total the survey was four pages in length and contained some 58 items in all. Establishing the ralidity and reliability of the survey instrument forms part of the analysis described beiow. Face validity was assured by the acceptance of the instrument by the panel of experts. However, construct raidity and internal consistency were also addressed by the statistical analysis.

\section{PROCEDLRE}

The most important aspect of procedure concerned the steps taken to insure a high response rate for the survev. This procedure can be described as a series cf contacts occurring in three stages.

\section{Pre-Survev Contact}

A postcard was mailed to ali individuais with a brief explanation of the study and its importance in their particular professional field (see Appendix F). The postcard indicated that the individual would receive a 
survey questionnaire within ten days. The cardalso highlighted the importance of the participants' responses.

\section{Cover Letter and Survey}

This correspondence included an explanation of the study, the purpose of the survey, and the importance of the research. The survey questionnaire and a postage-paid return envelope were included along with the cover letter. A time limit of three weeks was set for returns from the first mailing. (See Appendices $F$ and $G$.)

\section{Post-Survey Contact}

After three weeks, a follow-up postcard was sent as a third contact to encourage those who had not initially responded to take action and to thank those who had responded. (See Appendix $H$. ) Again, this card stressed the importance of the active participation of ail concerned to the successful completion of the study. A cut-off date was set for receiving and tabulating responses.

\section{DATA ANALYSIS}

The data analysis was conducted in two stages. The first was devoted to establishing the reliability and validity of the survey instrument. The second ras devoted to the description of the sample and the research questions. 
Validation of the instrument was limited to an assessment of its construct validity. According to Carmines and Zeller (1979):

- . construct validation has generalized applicability in the social sciences. The social scientist can assess the construct validity of an empirical measurement if the measure can be placed in theoretical context. . . Specifically, if the performance of the measure is consistent with theoretically derived expectations, then it is concluded that the measure is construct valid (p. 27 ).

Validation of the measures arising from the survey instrument thus depended on their successiul use in the investigation of the assistant principalship as a training ground. Results presented in Chapter IV will suggest that the instrument proved to be highly vaild.

Reliability of the survey items was assessed by evaluating the internal consistency of the subscales to be analyzed. This assessment of reliability is customarily eraluated by Cronbach's aipha (Nunnaily, 1978; Carmines i Zeller, 1979). Coeificient alpha was computed for each scale which combined the fourteen areas of responsibility. Descriptions of how each scaie was computed are prorided in Chapter IV.

The second stage of the analysis was devoted to a description of the sample and statisticai evaluation of the research questions. A series of univariate frequency distributions were used to assess the gender of the respondents, the numbers of years spent in the current 
administrative position, the number of $:$ ears respondents recommended be spent as an assistant principal, and the number of assistant principals in the respondent's school.

The analyses that addressed all three research questions used indices computed from the respondents, ratings of the fourteen areas as their dependent variables Isee Chapter IV for a detailed description of their construction). The first research question asked whether or not principals and assistants differed in their perceptions of the assistant principalship as a training sround. Depending on the level of measurement in the variables analyzed, a series of t-tests and chi-square tests were performed to assess differences in perception. When differences were detected, a more detailed analysis using comparative sraphs of univariate frequency distributions were employed to explore specific areas in detaii.

The second and third research questions asied what factors might influence the perceptions of principais and assistant principals. In these analyses, principals and assistants were analyzed separateiy. The bivariate relationships between a variable thought to be an influencing factor and the dependent variable was assessed using the student's t-test and the chi-square test once again.

A primary concern of the study was to explore differences in the perceptions of principais and assistants, 
but it was also theorized that gender may play an important. factor influencing these perceptions. Therefore, a final analysis explored the interaction between the respondents' status as principal or assistant ard gender in the expialation of the responderts ratings. Tho-hay analysis of varjance was used to conduct this assessmont.

\section{SLMMARI}

The research design for the study consisted of a analysis of responses from a mailed survey. Subjects for the study were $45+$ secondary school principals ard assistant principals who were members of the Confederation of Oregon School Administrators (COSA). No special sampining procedures were employed, since all secondary school administrators in the orsanization were surveyed. With over 900 members, representing many types of schoois, it is believed results will be widely generalizable.

The investigator designed the survey instrument for the study using the scientific literature, consultation with experts, and a pilot study. The instrument was comprised of 58 items and was four pages in length. Respondents nere required to rate fourteen areas of responsibility, such as discipline and activity supervision, for their usefulness in preparing the assistant principal for future administrative positions. Demographic items assessing the respondents' experience in the field of education were also included. 
Administration of the survey consisted of three steps: a mailed, pre-surver contact; mailing ô cover letter and survey; and a post-survey follow-up urging return of completed surveys.

Data analysis was focused in the areas of establishing reliability and validity, describing the sample, and addressing the research questions. 


\section{CHAPTER IY}

\section{RESLILTS}

The research questions were addressed through statistical analysis of the returned questionnaires. This chapter reports those findings. An overview of data processing and pre-analysis rariable manipulation wi i preceed a discussion of the sampie demographics. Discussion will then turn to the results wich portray simiiarities and differences in the perceptions of principals and assistant principals with respect to assistant principal training for the principalship. Factors wich influence these perceptions are also addressed.

\section{DATA PROCESSING AND PRE-ANALTSIS VARIABLE YANIPLLATION}

The 323 surveys returned were encoded on mark-sense reader forms to convert responses to machine readable form and were entered into the YAX/NiS computing sistem at the University of California, Irvine. Data files were then downloaded into a personal computer for analysis using Statistical Package for the Social Sciences (Norusis \& SPSS, Inc. . 19881 . 
Two major dependent variables were employed in the analysis: (1) an overail measure of the value of the assistant principalship as training sround, and (2) an overall measure of perceived stereotyping in the assignment of assistant principal responsibilities. These dependent variables were constructed from individuai questionnaire items. The overall measure of the value of perceived training, hereinafter referred to as TRAINING, was constructed from Question 1, items A through $\therefore$. These items asked respondents to rate the value of each of fourteen areas of responsibilicy on a six-point scaie ranging from 0 , not at all valuable, to 5 , extremeiy valuable. The variable TRAINING was created by summing the fourteen responses suppiied by each respondent to create a scaie score ranging from 0 to 70 .

An identical procedure was performed on Question $\because$. items A through $\AA$, in which respondents iere asked to rank the degree to which assistant principai job assignments are related to stereorypical beliefs about gender. Once again respondents were presented with a six-point scaie on which they ranked the degree of stereotæping they believed was present for that area. In overall measure of perceived stereotyping, hereinafter referred to as STEREOTYPE, was created by summing the fourteen responses and again producing a scale ranging from 0 to 70 . 
The reliability of these two indices as measures of the perceived value of training and presence of gender stereotyping can be evaluated statistically with a measure of their internal consistency. This assessment of reliability is customarily evaluated by Cronbach's alpha (Nunnally, 1978; Carmines \& Zeller, 1979). In this sample, high reliability coefficients resulted for both indices, .8759 for TRAINING and .9423 for STEREOTYPE. On the basis of these statistics, the two indices were included in the analysis as major dependent variables. Other dependent variables were also employed in the course of the analysis and are described below as the discussion warrants.

It was often desirable to modify the rating schemes in the two sets of fourteen items that were used to construct TRAINING and STEREOTYPE. Many results were easier to interpret and assess when the six rating categories used in the individual items were reduced to two. Thus in many of the graphic and tabular presentations to follow, the six rating categories used were reduced to two as follows: The ratings 'not at all', 'very little', and 'little' were placed in a single category described as 'no value to little value'. The ratings 'somewhat valuable', 'very valuable' and 'extremely valuable' were collapsed into a second category of 'somewhat to extremely valuable'. Thus, when the fourteen areas of responsibility used in the creation of 
both TRAINING and STEREOTYPE are presented individually, they often appear in this two-category form.

- DESCRIPTIVE ANALYSIS OF DEMOGRAPHIC DATA

All 454 members of the Confederation of Oregon School Administrators at the secondary level were surveyed in this study. Since 323 surveys were returned, the rate of response was calculated to be $i 1 \%$. The high rate of return suggested that the results presented beiow were representative of the group's membership and could be generalized with a moderate to high degree of confidence.

Although principals and assistant principals responded to the survey in nearly equal numbers 1138 and 184 , respectively), principals responded in greater proportion to the number surveyed: $75 \%$ of principals returned their surveys while only $68 \%$ of assistants returned theirs. However, since there were more assistants to begin with, the total of returned survevs produced a sample in which $\$ 3 \%$ were principals and $57 \%$ were assistants. (This was proportionally representative of the cosA secondary membership where approximately $40 \%$ were principals and $60 \%$ were assistant principals.)

Figure 1 summarizes demographic characteristics that further describe the sample of respondents. Male respondents outnumber their female counterparts by a wide margin, with $84 \%$ of the sample being male and $16 \%$ being 
GENDER OF PAINCIPAL AND A8BISTANT PRINCIPAL REOPONDENTS

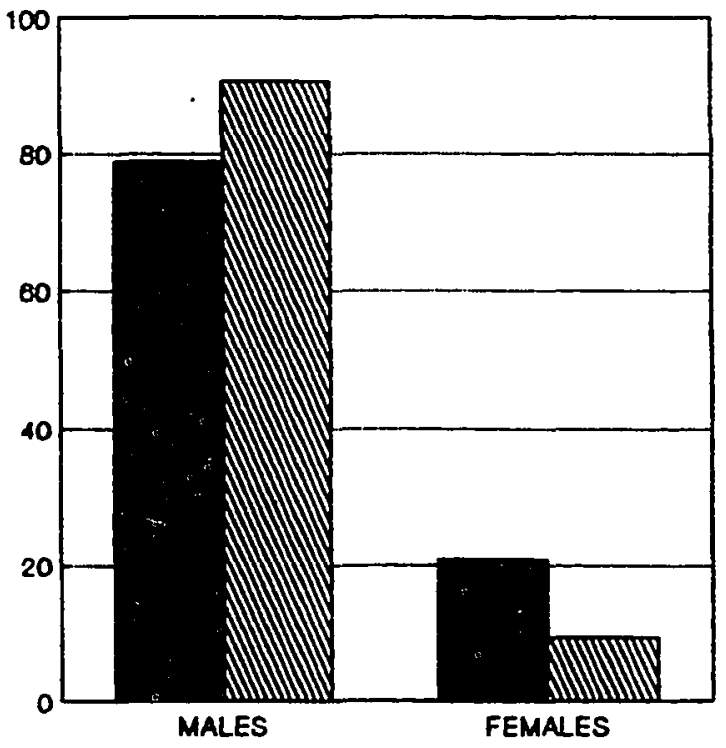

ASST PRINS IIIII PRINOIPALS

OHART $A$

NUMBER OF YEARB RECOMMENDED AS ASSISTANT PAINCIPAL

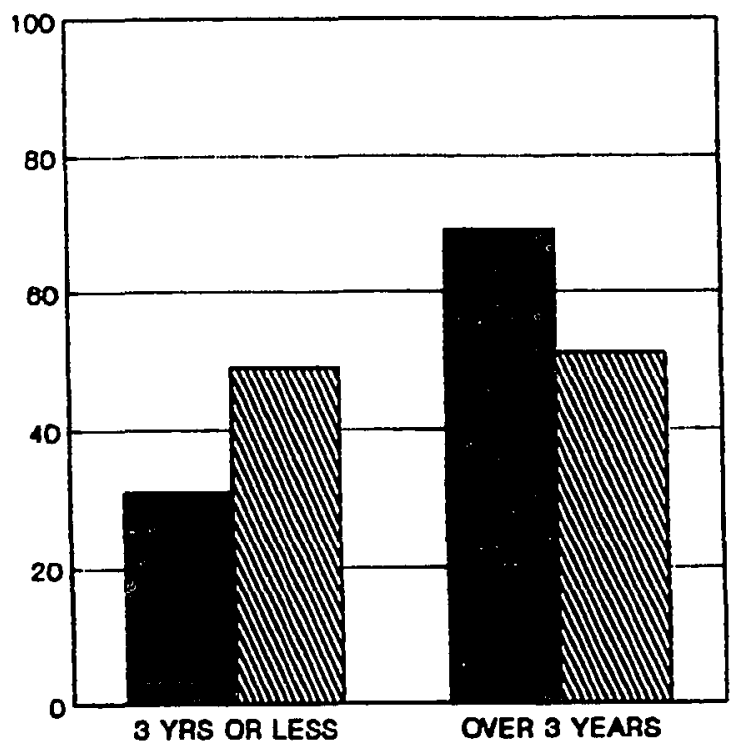

ABBT PRINS AIIII PRINOPALS

CHAPT C
NUMBER OF YEARB EXPERIENCE $\mathrm{N}$ PRESENT POAITION

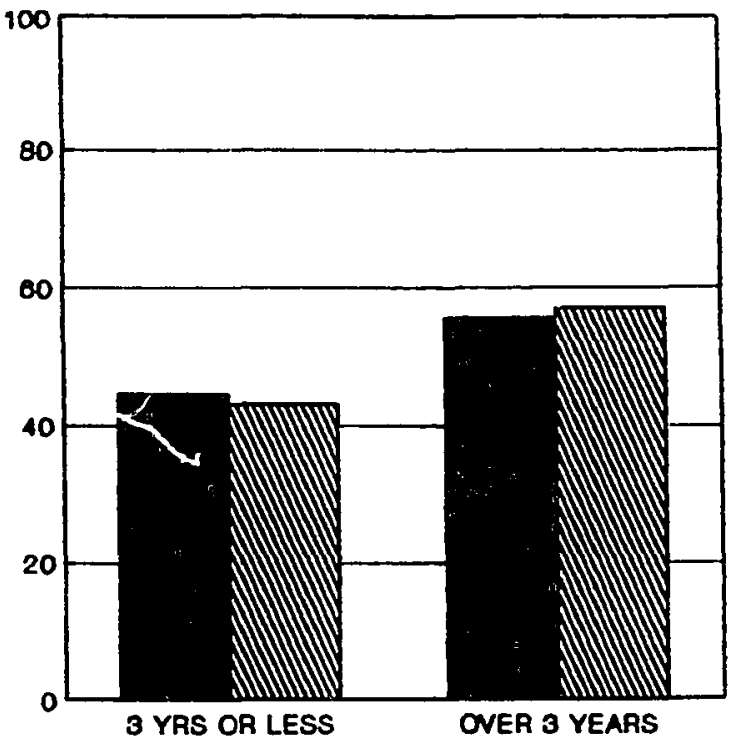

ASST PRIN8 IIIII PRINOIPALS

OHAAT B

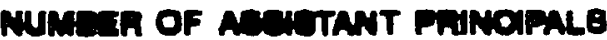
IN RESPONDENT'S SCHOOL

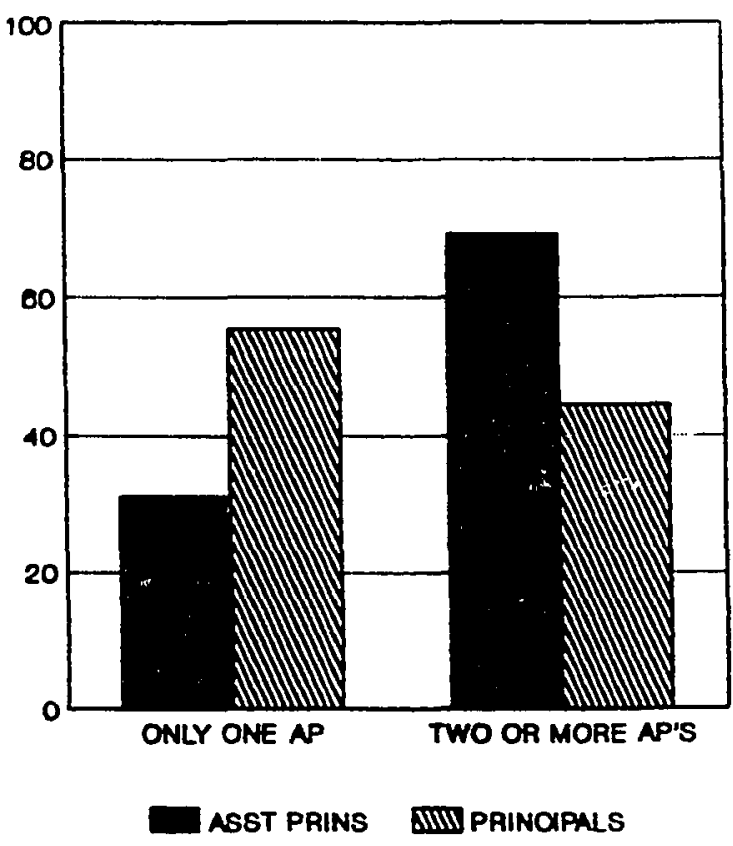

OHart D

Figure 1. Demographic information. 
female. This was also proportionally representative of the COSA secondary membership where approximately $88 \%$ were male and $12 \%$ were female. Chart it depicts the gender of the respondents as well as their status as principals or assistants and shows that $79.2 \%$ of assistant principals were male, while $20.8 \%$ of assistants were female. The difference between male and female principals was even wider with $90.6 \%$ of principals being male and only $9.4 \%$ being female. The chart also illustrates the point that a higher proportion of male respondents were principais and a higher proportion of femaie respondents were assistant principals.

Chart $B$ in Figure 1 depicts the number of years both principals and assistants have held their present position. In the majority of cases respondents from both groups had been in their current position over three years. Moreover, both groups were nearly equally represented in both time categories, so that equai numbers of principals and assistants had been in their jobs three vears or less and over three rears.

Respondents were asked to recommend how long assistant principals should serve in that position in order to be adequately trained for promotions to the principalship. Assistants and principals disagreed about the time that should be served. This result is shown in Chart $C$ of Figure 1. Principals were equall: divided in their recommendations, with half $(49 \%)$ recommending three rears or 
less and half $(51 \%)$ recommending over three years. Assistant principals, on the other hand, recommended a longer time period by nearly a two-to-one margin $169 \%$ is. $31 \%)$. Not shown in the chart, principals were also asked to state how long a period they served as assistants before being promoted to principal. Their time in the assistant principalship very nearly matched their recommendations with $42 \%$ having spent three rears or less as an assistant and $58 \%$ having served over three :ears.

Respondents raried with respect to the size of the administrative staff on which they served. Since it was believed that this number may affect their perceptions of the work environment in various ways, respondents were asked to report the number of assistant principals employed in their high school. These results are summarized in Chart $D$ of Figure 1. More assistants $(69 \%$ vs. $31 \%)$ reported that ther serred on a siaff having more than one assistant principal. The opposite was true for principals; a minority of principals $(44 \%$ rs $56 \%$ ) were members of a staff having more than one assistant principal. This seems to indicate that most $(56 \%)$ of the principals in this sample work alone or with only one assistant and that most assistants (69\%) di:ide the assistant principal's responsibilities with others.

A final question in the demographic category required respondents to report which of the fourteen areas of 
responsibility they were involved in on a daily basis. The fourteen areas are summarized in Table $I$, which also presents a series of two-letter abbreviations for the areas used throughout the tables and figures presented below. Figure 2 summarizes the percentage of principals and assistant principals who reported daily involvement in each area.

As seen in the figure, the area of evaluation (EV) involved over $80 \%$ of administrators from both categories on a daily basis. I similar pattern of neariy equai management by both principals and assistants was seen in the areas of athletic supervision (AT), activity supervision (AC), guidance and counseling (GD), and special education (SE), although the proportion of individuals reporting involvement in these areas was less. In other areas, however, the involvement of assistants and principals was less balanced. Principals indicated greater intolvement in the areas of curriculum development (CD), hudgetary process (BG), community relations (CR), staff deveiopment (SD), maintenance (YN), school improvement (SI), hiring and selection (HS), and improvement of instruction (II). Assistant principals were more often charged with discipline (DC) 
TABLE I

DEFINITIONS FOR ASSIGNMENT ABBREVIATIONS

$\begin{array}{ll}\text { DC } & \text { Discipline } \\ \text { BG } & \text { Curriculum Development } \\ \text { CR } & \text { Budgetary Process } \\ \text { EV } & \text { Community Relations } \\ \text { SD } & \text { Teacher Evaluation } \\ \text { MN } & \text { Staff Development } \\ \text { AT } & \text { Maintenance } \\ \text { AC } & \text { Athletic Supervision } \\ \text { SI } & \text { Activity Supervision } \\ \text { GD } & \text { School Improvement } \\ \text { HS } & \text { Guidance and Counseling } \\ \text { SE } & \text { Hiring and Selection } \\ \text { II } & \text { Special Education } \\ & \text { Improvement of Instruction } \\ & \text { Abbreviation }\end{array}$




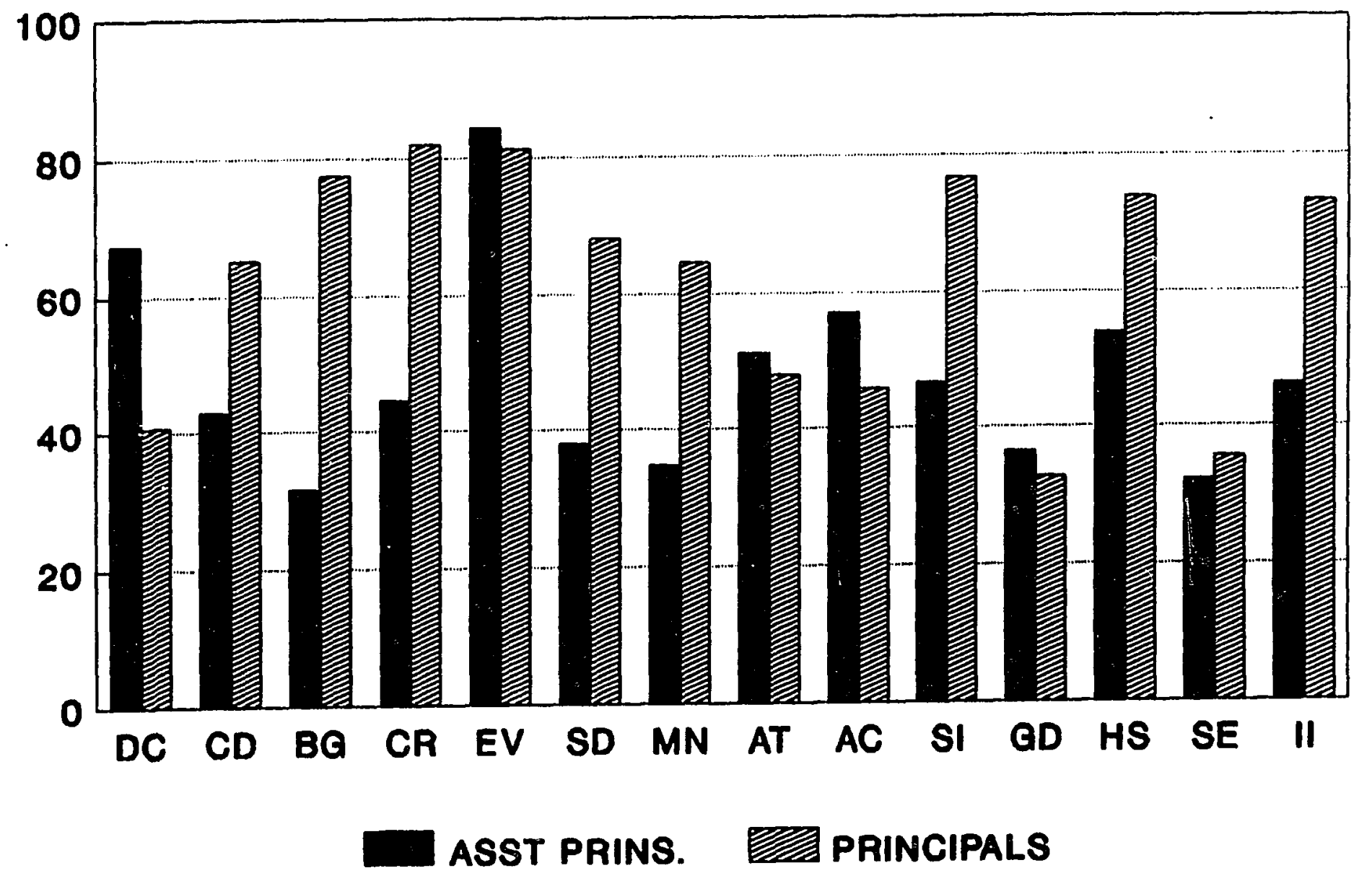

Figure 2. Comparison of principal and assistant principal dnily responsibilities. 


\section{PERCEPTIONS OF THE ASSISTANT PRINCIPALSHIP \\ AS TRAINING FOR THE PRINCIPALSHIP: \\ DIFFERENCES BETWEEN PRINCIPALS \\ AND ASSISTANTS}

The first research question addressed the issue of the quality of training received in the assistant principalship. It asked: Do principals and assistant principals differ in the extent to which they perceive the assistant principalship as an adequate training sround for the principalship?

When principais and assistants are combined in a single analysis, the sample size is 323 , which is large enough to detect very small statistical differences if the alpha to reject the null hrpothesis is set at the customary .05 ievel. In order to insure that signficant results were also relatively important to this area of research, i.e., of some consequence to the educationai research community, the decision was taken to set alpha at .U1 when the entire sample of 323 was inciuded in an analysis. then subsampies were analyzed, e.g. principais alone or assistants aione, the usual .05 level to reject would remain in force.

The survey queried principais and assistants about their perceptions of the assistant principalship as an adequate training ground in three ways: 11 ) the overall vaiue of the assistant principalship as a training 3 round, (2) the value of each of the fourteen areas of 
responsibility as training, and ( 3 ) the value of additional factors in training.

\section{Overall Perception of Training}

Question 12 on the survey (see Appendix G for the complete surveyl asked respondents to rate the experiencies of the assistant principalship in seneral as appropriate preparation for the principalship. They were asked to indicate, on a six-point scale ranging from 0 to 5 , whether the preparation provided was not at all useful, of rery little use, little use, somewhat useful, very useful, or extremely useful. In order to assess whether principals and assistant principals differed in their rating of this general form of the question. The six categories of rankings were reduced to two ' hot at all useful to little use' and 'somewhat to extremely useful', as described above. Then, the responses of principals and assistants were compared and a chi-square statistic lias computed to test for significant differences in perceived value. The resulting comparison is depicted in Figure 3. The Figure shows that $9.8 \%$ of assistants and $14.5 \%$ of principals rated the assistant principalship as not at all useiul or of litle use, while $90.2 \%$ of assistants and $85.5 \%$ of principais rated it somewhat to extremely useful. The Chi-square statistic of 1.22 (with $d f=1$ ) was non-significant, indicating no difference in the perceptions of principals and assistant 
principals. As suggested by Figure 3 , both groups tended to rate the assistant principalship highly useful as a training ground.

Percertion of Training by Indivjdual Area

A second approach to this research question was to examine djfferences in the perceived value of training as indicated by the ratings given by principals and assistants to the fourteen areas of responsibjlity. The areas of responsibility were taken one at a time and then summed to form the TRAINING index described above. This way of measuring the respondents' perception of the assistant pribcjpalship as training ground differed from the first approach in-as-much as it allowed them to rank one area of responsibility at a time rather than approach the issue of preparation generally. Once combined in a scale, it was assumed by the investigator, that the TRAINING index would provide a more sensitive measure of the respondents' perceptions. Thus a Student's t-test was applied to assess differences in the mean TRAINING index scores for principals and assistants. The mean for principals was $39.78 \quad n=138$ ) while that for assistants was considerably higher at 46.98 $(n=184)$. A $t$-value of $4.83(\mathrm{df}=320)$ was found to be significant $(\mathrm{p}=.000)$, and indicated that assistants ranked the value of the assistant principalship as a training ground significantly higher than principals. 


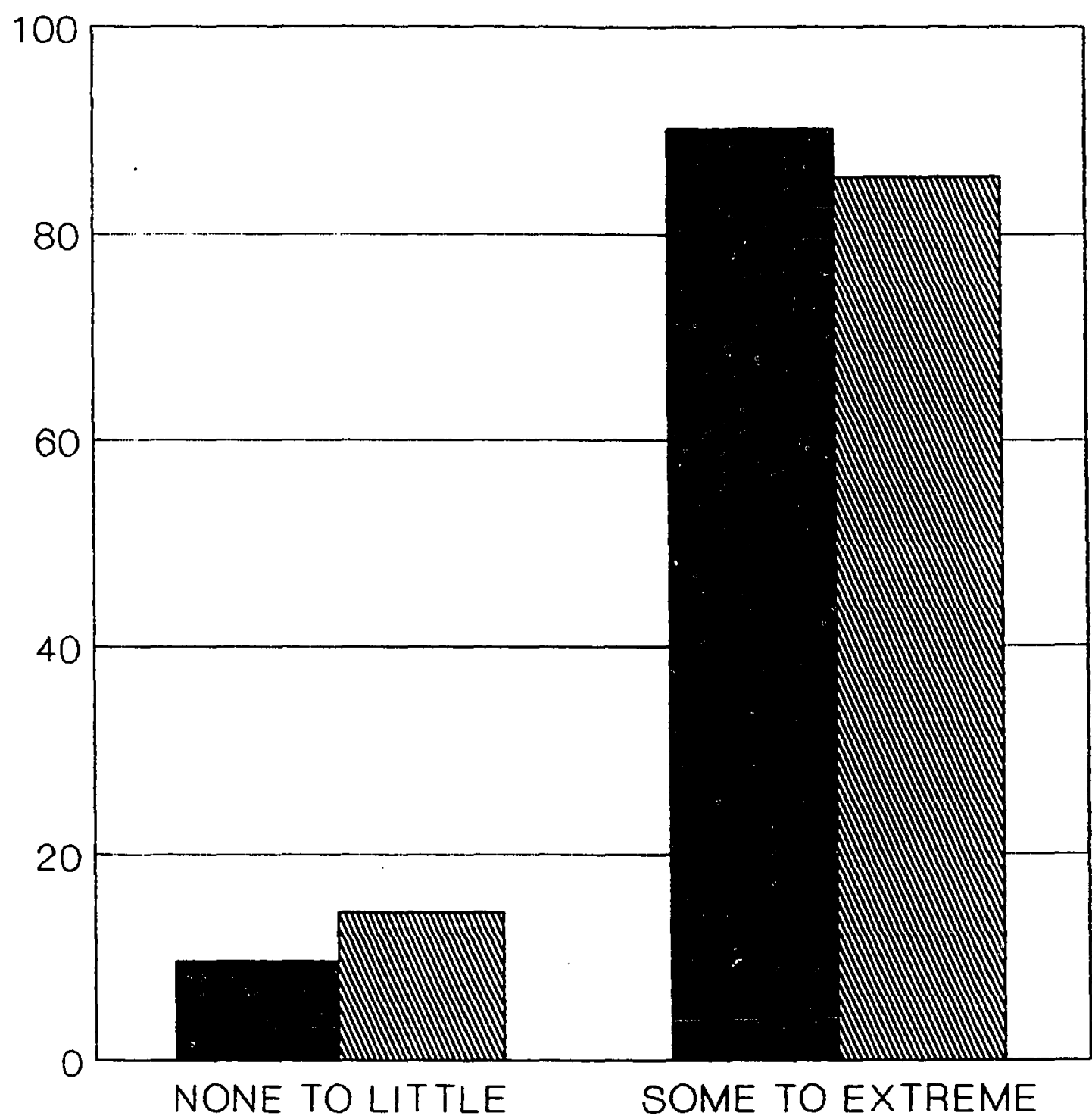

ASST PRINS PRINCIPALS

Figure ${ }^{3}$. Perceived training value of assistant principal position. 
since the TRAIXIIG index of respondents: ratings was a composite score assessing ratings over $i t$ areas of responsibility, a more detailed analysis was conducted to assess which areas contributed to the differences detected by the t-test. The results of this analysis are presented graphically in Figure 4 .

To create Figure 4 , each of the fourteen areas of assistant principal responsibility was recoded into its tiocategory form, 'no vaiue to little value' and 'somewnat to extremely valuabie'. Then, the percentage of respondents rating each area 'somewhat to extremely raluable' was plotted on the graph.

The graph depicts two areas of interest. First, which areas principals and assistants rated most valuable for the training of assistants and, second, how their perceptions differed. The topic of most highly rated areas is addressed first. There were five areas rated "somewhat to extremeir valuable" by more than $80 \%$ of assistant principals. They were discipline (DC), community relations (CR), evaluation (EV), activity superrision $(\mathrm{AC}$, and school improvement (SI). Principals gave their highest ratings to four of these areas. They were discipline $(\mathrm{DC})$, community relations $(C R)$, evaluation (EV), and activit: supervision (AC). Principals replace school improvement (SI) with guidance and counseling (GD) in their highest ratings. These ratings can be compared with the actuai daily responsibilities of 


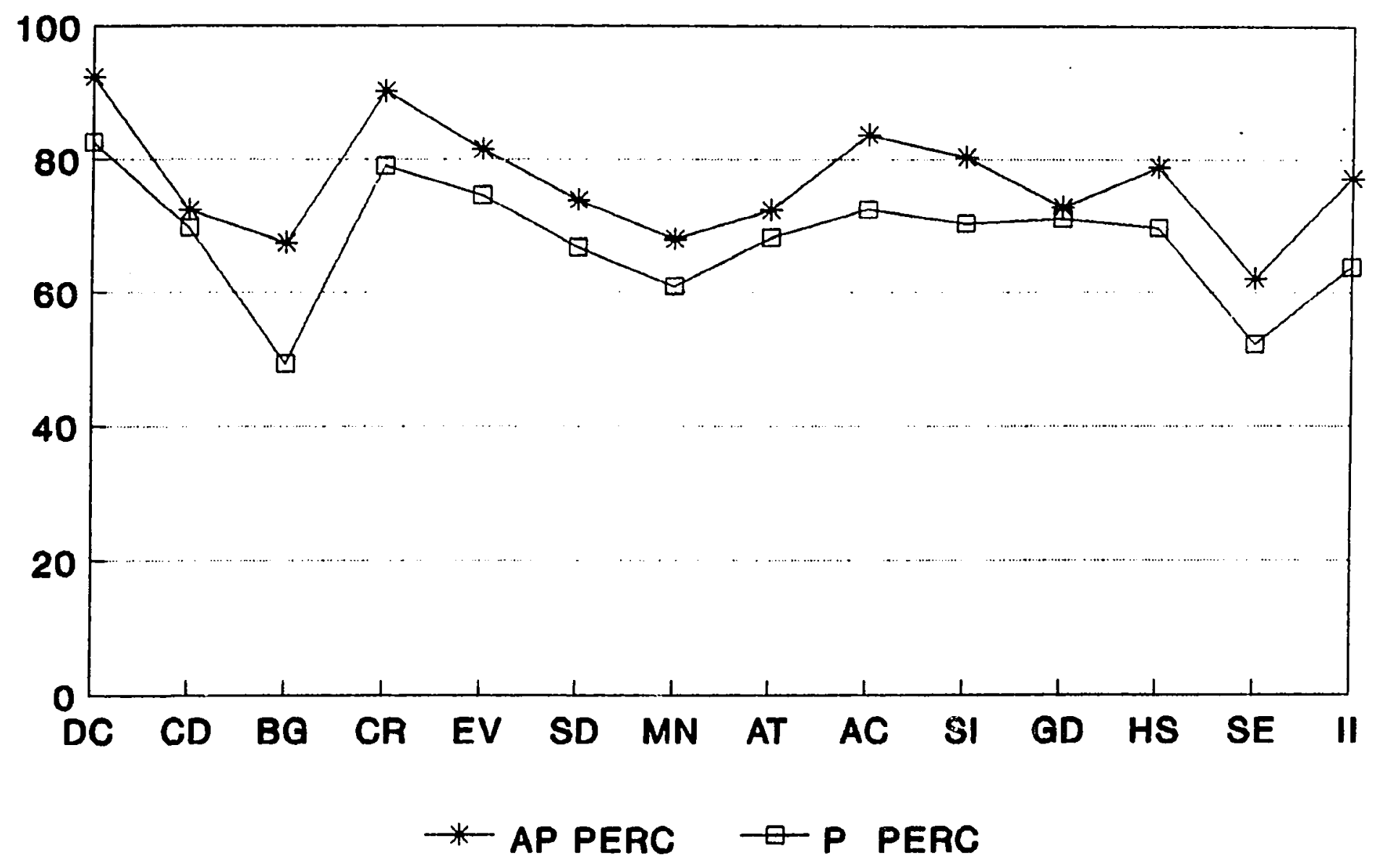

Figure 1. Iomparative importance of astisitant princilal duliess. 
assistants and principals (see Figure 2). Assistants are more frequently assigned than principals to discipline, evaiuation, and activity supervision and less frequentiy assigned than principals to the highly rated areas of community relations and school improvement. In a similar vein, assistant principals are more frequently assigned to the area of guidance and counseling, the area in which principals and assistants differed in their ratings of the five most important areas.

Differences in the perceptions of principals and assistants werc a consequence of the fact that the percentage of assistant principals who rated the usefuiness of the areas 'somewhat to extremeir raluable' was consistently higher than the percentage of principals. This created a small, but uniform difference. The curves for the two administrative categories are similar in shape cut difierent in magnitude. Two exceptions ro this general observation were in the areas of curriculum deveiopment $(\because D)$ and suidance and counseling (GD) where the two groups of administrators were nearl cqual in their ratings.

By way of summary, it should be noted that the two approaches to differences in principals' and assistants' perceptions rieided different results. When queried in seneral about the usefulness of the assistant principaiship as a training ground, no significant differences in principals' and assistant principals' perceptions were 
found. However, when ratings of individuai areas were combined in a TRAIXING index, significant differences in principal and assistant mean scores were found. A graphic analysis of ratings of individual items showed this difference could be attributed to the fact that more assistant principals than principals rated each area 'somewhat to extremely valuable'. It may aiso suggest that differences which were imperceptible to the raters when presented with the seneral form of the question became more sailent when they rated one area of responsibility at a time.

\section{Perception of Additional Factors}

Differences in principal and assistant principal perceptions was focused in survey questions 3 through il which were concerned with the nine areas of: (1) superision and evaluation duties; $(2)$ staff romplaints and problems; $\quad$ : $!$ size of aciministrative stäf $; \quad 1+1$ clarification of the role of the assistant principal; (5) the assistant principaiship as a satisfactory goai in and of itself; (6) the number of assignments given each assistant principal; (i) the specialization of job assignments; (8) professional interaction: and (9) communication between the assistant principal and principal. Separate chi-square tests for the reiationship between ratings in each of the nine areas and the principal or assistant status of the 
respondents riere computed. With the aipha level set at .01 to reject the null hypothes, none of these areas were found to be significantly associated to the administrative status of the respondents. It was concluded that there were no differences in the principals' and assistants' perceptions of the value of these areas for training.

\section{FACTORS AFFECTING THE PERCEPTIONS OF ASSISTANT PRINCIPALS}

Research question 2 asked what factors affected the assistant principais, perceptions of the assistant principalship as a training ground. The anaissis presentea below investigated the potential for four factors to affect their perceptions: (1) the number of other assistant principals with whom the respondent worked (staff size): (2) whether or not assistants believed the assistant principalship was a satisfactory carcer yoal in its chn right: $(3)$ whether the assistants bere actuaily assigned : 0 an area; and $(t)$ whecher or not sender atfected tineis perceived value of training.

\section{Staff $\underline{\text { Size }}$}

The first factor investigated was the number of assistant principals working in the same school as the respondent. The investigator hypothesized that assistant principal perceptions of training may be related to the size of the administrative staff. The fewer assistants in a 
school, the greater the number of areas of responsibilit: each will be assigned. Similarly, the greater the rumber of assistants, the fewer areas of responsibility availatle for each. Thus, the kind of experience each assistant can have may be related to the number of other assistants in the same school.

To explore the relationship bethech staff size aud Hejcentions of training, a t-test was computed which compared the mean TRAINISG index for assistants in schools with one assistant priricipal with that for assistants in schools with two or more assistant principals. The mean for responderts in schools with onc assistant principal was 1.1.11 (n=56) while that for respondents in schoois with two cr more assistant principals was four points higher at 48.22 $(n=127)$. This difference produced a significart t-value of $-2.69(\mathrm{df}=181, \mathrm{p}=.008)$ indicating that respondents ir: schools with two or more assistant principals rated the value of their training higher.

In Figure 5, the percentage of assistant principals rating each area of responsibility 'somewhat to extremeiy raluable' are shown. The ratings of assistants in schools with one assistant principal are contrasted with those from schools with tho or more assistant principals. Of the fourteen areas rated, only four received similar ratings from both groups of assistants: discipline (DC), community relations (CR), athletic supervision (AT), and hiring and 


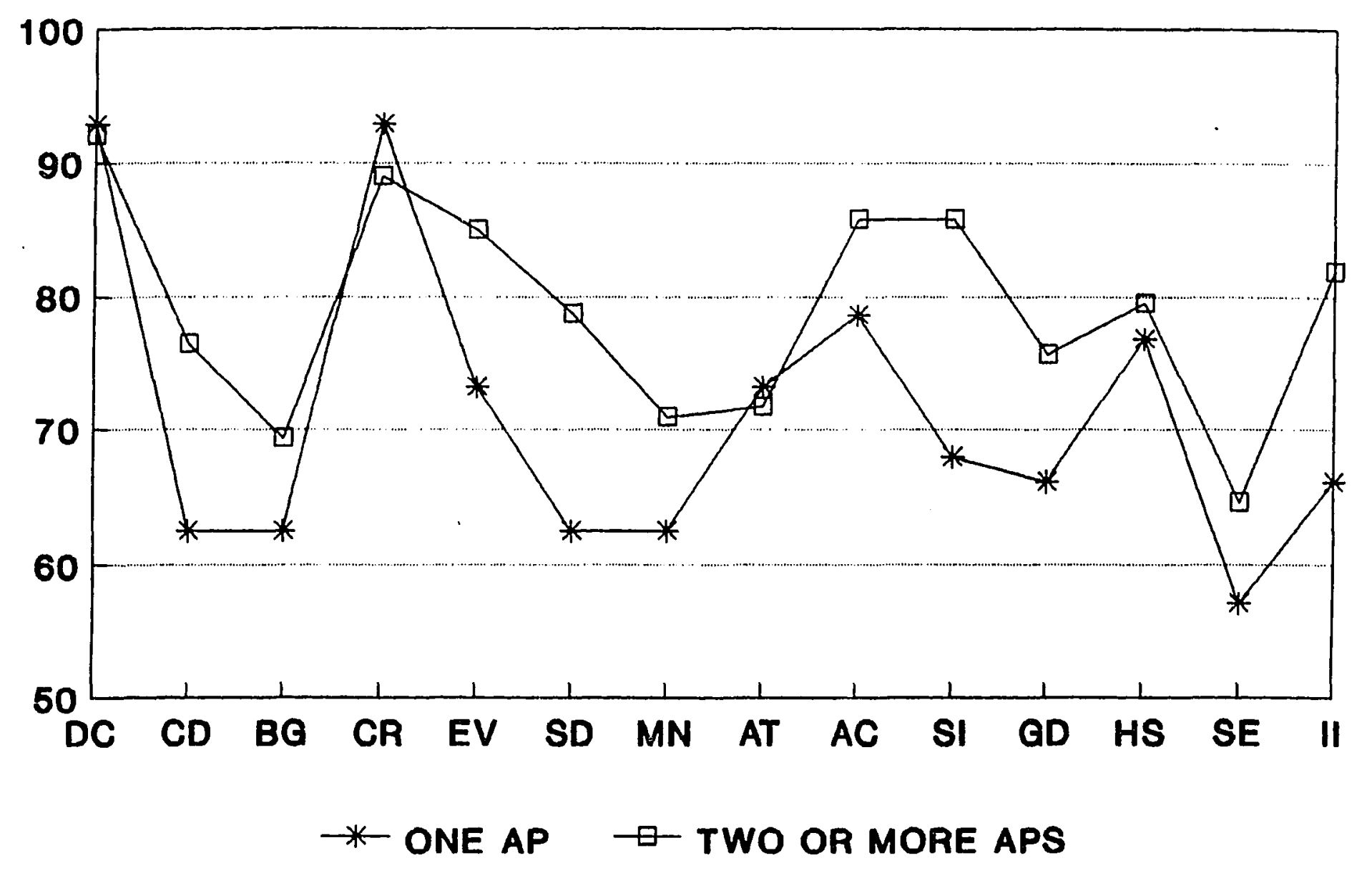

Figure 5. Differonces in percoived value of training in small is. large staffs. 
selection (HS). In all cases but three, higher ratings were awarded by respondents from schools with two or more assistant principals.

One theory put forward earlier in regard to the issue of staff size was that staff size affected perception by limiting the areas of responsibility assigned. To explore this facet of the analysis in greater depth, a second graph was computed depicting the proportion of respondents actually assigned to each area in schoois with one, or two or more, assistant principais. These resuits are portrayed in Figure 6. The ijgure reveals that although trainingvalue ratings for the two sroups were moderately dissimilar, their actual assignments are similar to one another. Both the shape of the curves and the height of the points plotted on the scale are also similar. However, there were seven areas where assignments differcd according to staff size. They were curriculum aevelopment (CD), athletic supervision (AT), activity supervision $(H C)$, guidance and counseling (GD), hiring and selection (HS), special education (SE), and improvement of instruction (II). Although the proportion of assistants actually assigned to each area of responsibly appears to be unaffected by staff size, there are differences in half of the areas. At the same time, the significant t-test indicated that staff size did influence the assistant principals' perception of their training. 


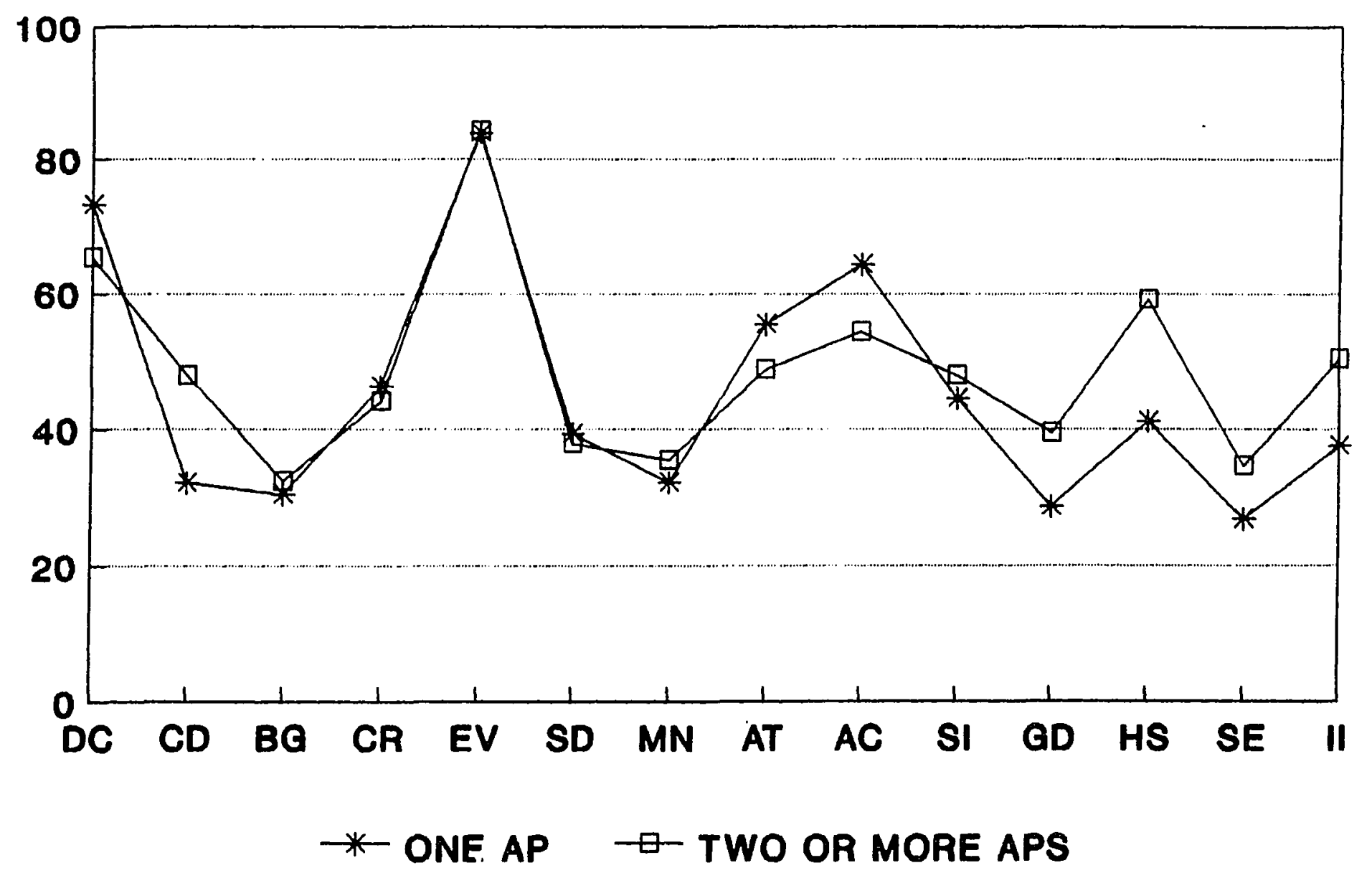

Eigure 6. dssistant principal assignments in schools with small is. large staffs. 
Assistant Frincipalship as Career Goai

A second factor believed to affect the assistant principals' perceptions of their training was whether or not they believed the assistant principalship was a satisfactory career goal in and of itself. A majority of the assistants ( $76 \%)$ who responded indicated that the assistant principalship was indeed a satisfactory career goal, while $24 \%$ believed it was not. Did assistant principals who aspired to become principais perceive the vaiue of the assistant principalship as a training zround differentir than assistant principals who were not interested in promotion? At-test was computed to compare the ratings of the training value of the assistant principaiship ror these two groups. Those who believed the assistant principaisinip to be a satisfactory career had a mean on the TRAINING index of $17.33(n=i+0)$, while those who beileved it was not

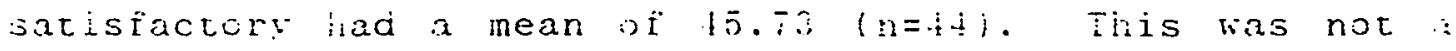
significant difference. Issistants: percotions ot the ralue of their training was apparently inaffocted ly their beliefs of the assistant principaiship as a satisfactory career goal.

tctual Assigninents

$\rightarrow$ third factor concerned whether actual assignments affected the eraining-value ratings given individual areas of responsibility. It was reasoned that areas to which the 
assistants were assigned would receive greater importance than those in which they were uninvolved. This reasoning was tested by crosstabulating the assistants' actual areas of assignment with the ratings they gave each area as a training ground for the principalship. A Chi-square test was applied to each crosstabulation to assess tine statistical relationship between actual assignment to an area and the rating it recieved. Those results are presented in Table II.

The table reports the percentage of assistants who rated an area 'somewhat to extremely raluatle' and onits those rating the area 'not at ail to little vaiue'. (For this reason percentages will not total $100 \%$, The tabie then compares the percentage of assistants who gave high ratings and were assigned to an area with those who gave high ratings and were not assigned. The chi-square tost and Fobabilit: of observing this aifference by chance are also reported.

The table indicates that the training-ralue ratings given by assistants to each area of responsibiitt: were highly related to the areas they were currently assigned. when an assistant was actually assigned to an area, he or she tended to rate the ralue of the area is a training sround higher. For example, assistants who were charged with hiring were more likely to rate this arein inisher than assistants who were not involved in hiring. There tiere 
TABLE II

COMPARISON OF TRAINING-VALUE RATINGS WITH ASSISTANT PRINCIPALS' ACTUAL ASSIGNMENT

\begin{tabular}{|c|c|c|c|c|}
\hline AREA & $\stackrel{\%}{\text { ASSIGNED }}$ & $\begin{array}{c}\% \text { VOT } \\
\text { ASSIGNED }\end{array}$ & $\begin{array}{l}\text { CHI- } \\
\text { SQUARE }\end{array}$ & PROB \\
\hline DISCIPLINE & 96.0 & 84.5 & $i .34$ & .007 \\
\hline CURR DEVLOP & 92.4 & 56.9 & 28.13 & .000 \\
\hline BUDGET & 87.9 & 58.5 & 15.55 & .000 \\
\hline COMM. RELATIONS & 95.1 & $8 \overline{1} .1$ & 3.43 & $\therefore . S . *$ \\
\hline EVALUAT ION & 85.2 & 62.1 & 8.65 & .003 \\
\hline STAFF DEVELOP & 80.0 & 70.0 & 2.22 & N.S. \\
\hline MAINTENANCE & 79.7 & 61.5 & 6.26 & .012 \\
\hline ATHLET SUPERVIS & 84.0 & 59.1 & 14.03 & .000 \\
\hline ACTIVITY SUPERV & 83.8 & 34.2 & 0.01 & $\therefore . S$ \\
\hline SCHOOL IMPROVE & $88 \cdot 4$ & 72.3 & 6.80 & .009 \\
\hline GUIDANCE & 85.1 & 66.7 & i. .29 & .007 \\
\hline HIRING & 90.9 & 92.3 & $\because 0.39$ & .600 \\
\hline SPECIAL ED & 84.7 & 51.2 & $19.0-i$ & .000 \\
\hline IMPROVE INSTRUC & 85.9 & $68 . t$ & 7.16 & .008 \\
\hline
\end{tabular}

*iv.s. $=$ not significant 
three exceptions to this general observation. They were in the areas of community relations, staif development, and activity supervision where no significant difference in percentages was found.

Several other observations concerning this set of relationships can be made from Table II. First, all assistants tended to rate the value of eacin of the areas fairly high. For example, even among assistants not assigned to an area, the percentage of respondents rating the area 'somewhat to extremeiy valuable' never feil below $51.2 \%$. By the same token, among assistants who were assigned to an area, the percentage rating, somewhat to extremely valuaile' never fell beiow approximately $80 \%$.

This result can be reinforced by examining the comparisons sraphically. Figure $i$ piots the percentage oi issistants rating the areas 'somewhat to extremcig 'aiuable' aicngside the percentage of assistants actuail issimned $\Rightarrow$ a given area. The strength of the resule is scer fron the fact that the shape of the two curres is virtuaily identical. With exception of the area of evaiuation (EV), this observation can be interpreted to mean that rhe relative worth of each or the areas as a training ground is a function of the number of assistants who are invoived in these assignements on a dail 


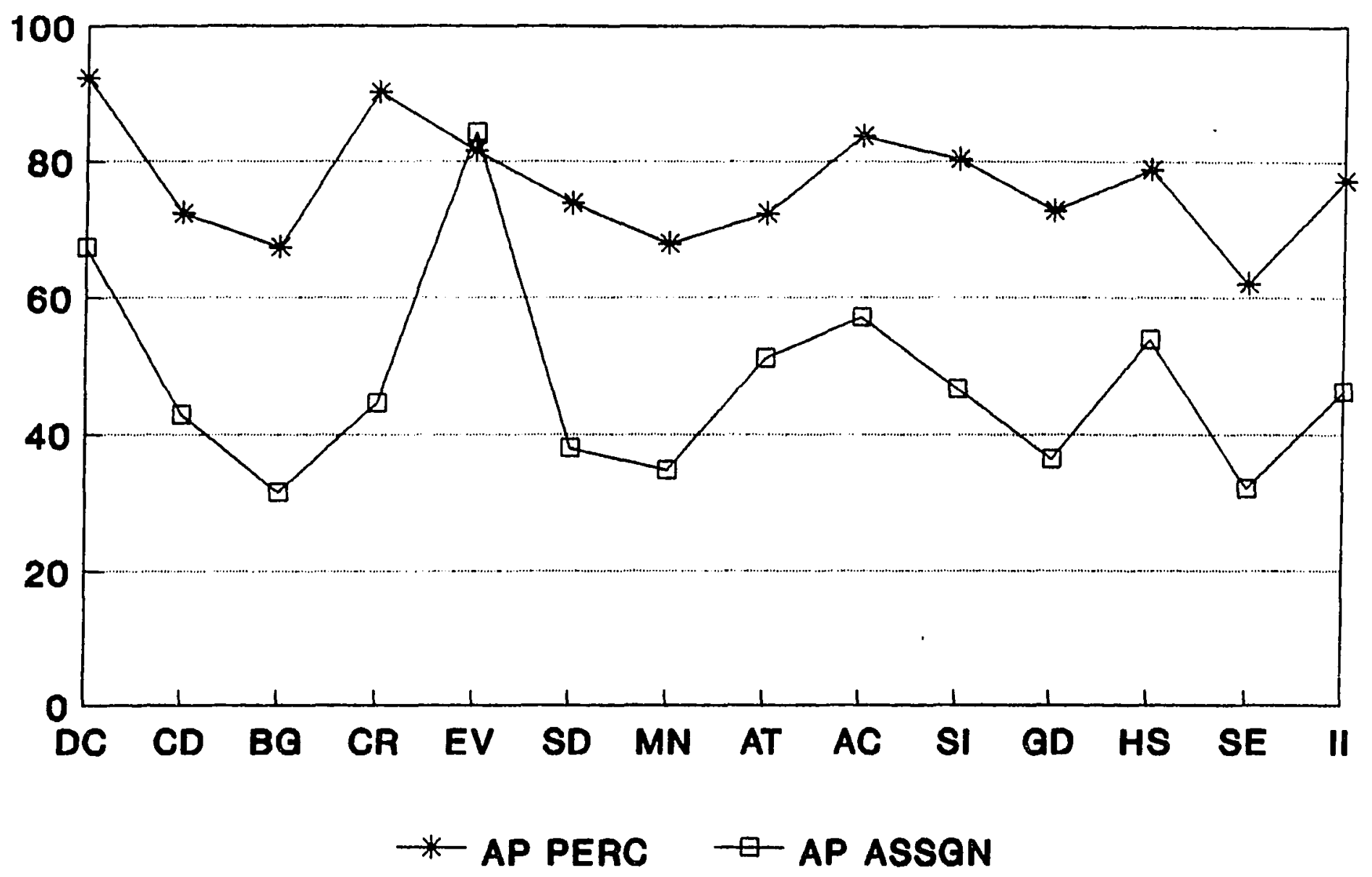

Figure I. Comparison of assistant principal perceptions with assignments. 
Gender

Gender was a fourth factor believed to affect the assistant principais' perceptions of their training. Three separate analyses were used to explore the influerce of gender. First, male and femaie assistants, ratings of their training as measured by the TRAINIXG inde: were compared using the t-test. Second. maie and female perceptions of the extent to which jub assignments were sased on sender, as measured by the STEREOTYFE indox, were compared using the $t$-test. Third, ia statistical assessment was made to determine whether maic and femaic assistants were actually assigned to specific areas in proportions greater than would be expected by chance. In the paragraphs following each of these analyses is described in turn.

It was hypothesized that naies and females could vier: the ralue of their training differenty. Since maic assistants outnumbered their temaie counterpares by a sizeable nargin--there were neariy four times as manr maie assistants--females mat view their experience differenty than males in the same position. This was tested assessing male and femaie scores on the TRAINING index. I t-test showed males with a mean score of $46.12(n=1.15)$ and femaies with a mean score of $50.63(n=38)$. with df $=1 \varepsilon 1$, a $t$ - value of -2.61 was found to be signifieant ip=.jil. vale and female assistant principals viewed the raiue of 
their training differentiy, with more females viewing the experience as valuable.

Once again a graph was prepared in which the proportion of male and females assistants reporting an area 'somewhat to extremely valuable' was plotted. Those ralues are depicted in Figure 8. There were two points along the curves in which male and female assistants tended to agree on the worth of a particular area in training. They were budgetary process (BG) and community relations (CR). Males rated the areas of discipline (DC), maintenance (MN), athletic supervision (AT), and school improvement (SI) higher than females. The female assistants rated the value of the remaining areas higher than the males. These areas were curriculum development (CD), teacher evaluation (EV), staff development (SD), guidance and counseling (GD), hiring and selection (HS), special education (SE), and improvement of instruction (II).

It was also hypothesized that male and female assistant principals might perceive differences in the degree to which job assignments were made on the basis of gender. To address this question the STEREOTYPE index was used as the dependent variable. This composite measure was the sum of the respondents ratings of the extent of stereotyping in each area of responsibility. At-test comparing male and female assistants' ratings on this index showed a mean STEREOTYPE score of $12.87 \quad(n=145)$ for maies 


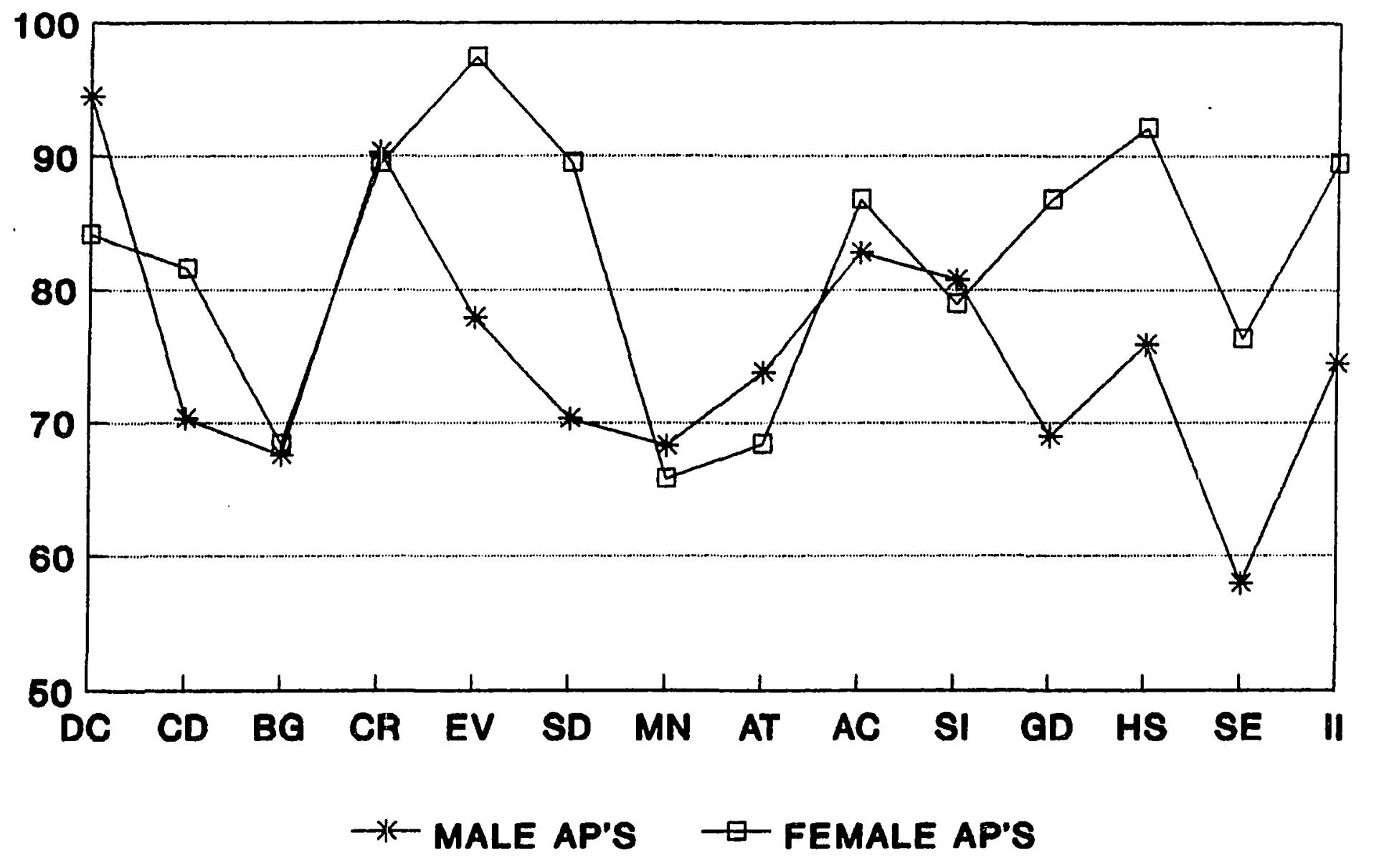
Figure
training
index items. 
and $13.32(\mathrm{n}=38)$ for females. With $\mathrm{df}=181$ and a t-value of -0.18 , there was no significant difference in the mean STEREOTYPE score for male and female assistant principals.

Item $G$ on page four of the questionnaire (see Appendix G) asked each respondent to indicate the area to which he or she was actually assigned. With this information it was possible to evaluate the extent to which male and females were actually assigned to particular areas of responsibility at a rate higher than would be expected by chance. The gender of the 184 assistant principals was cross-tabulated with each area of responsibility, and a Chi-square test was computed to assess the strength of association between gender and each assignment area. A significant correlation was found in four areas: discipline, athletic supervision, maintenance, and improvement of instruction. The proportions of male and female assignments to these areas is summarized in Table III. The table illustrates that males were assigned to discipline, athletic supervision and maintenance more frequently than would be expected by chance while the same was true for females assigned to the area of improvement of instruction. It is interesting to note that women were assigned to the areas of discipline, maintenance, and athletic supervision less often than men and women perceived them as less valuable assignments (see Figure 8). The differences between male and female assignments across all fourteen areas of responsibility are plotted in 
TABLE III

GENDER AND ASSIGNMENT AREAS

\begin{tabular}{|c|c|c|c|c|}
\hline AREA & $\begin{array}{c}\% \\
\text { MALES }\end{array}$ & $\begin{array}{c}\% \\
\text { FEMALES }\end{array}$ & $\begin{array}{c}\text { CHI- } \\
\text { SQUARE }\end{array}$ & PROB. \\
\hline DISCIPLINE & & & 5.62 & .017 \\
\hline assigned & 83.9 & 16.1 & & \\
\hline not assigned & 68.4 & 31.6 & & \\
\hline MAINTENANCE & & & 8.21 & .004 \\
\hline assigned & 90.6 & 9.4 & & \\
\hline not assigned & 72.4 & 27.6 & & \\
\hline ATH. SUPERVISION & & & 4.07 & .044 \\
\hline assigned & 84.9 & 15.1 & & \\
\hline not assigned & $72 \cdot 7$ & 27.3 & & \\
\hline IMPROVEMENT OF & & & & \\
\hline INSTRUCTION & & & 4.31 & .038 \\
\hline assigned & 71.4 & 28.6 & & \\
\hline not assigned & 84.4 & 15.6 & & \\
\hline
\end{tabular}


Eigure 9, which supports the statistical summary presented in Table III. As seen in the graph, nost assigrmert aroa:s are neutral with regard to gender, the exceptions being discipline (DC), maintenance (MN), athletic supcrision (AT), and improvement in instruction (II).

\section{FACTORS AFEECTING PRINCIPALS PERCEPTIONS}

Research question 3 asked what factors influenced tho perceptions held by principals of the training value of the assistant principalship. It was hypothesized that principals' perceptions could be affected by four factors: (1) the amount of time they served as assistant principals; (2) the length of time they had been principals; (3) the number of assistant principals they currently supervised; and $(t)$ sender. This section reports results of thesc anaylses.

\section{Principals' Experience as Assistant Principals}

Familiarity with the assistant principal's positiori was believed to affect the principals' rating of each area as a training ground. Thus, time spent in this position might account for differences in the percentages of principals who rated each area 'somewhat to extromely valuable'. To test this belief, a t-test was computed to compare differences in the mean TRAINING index score for principals who had spent three years or less as assistints 


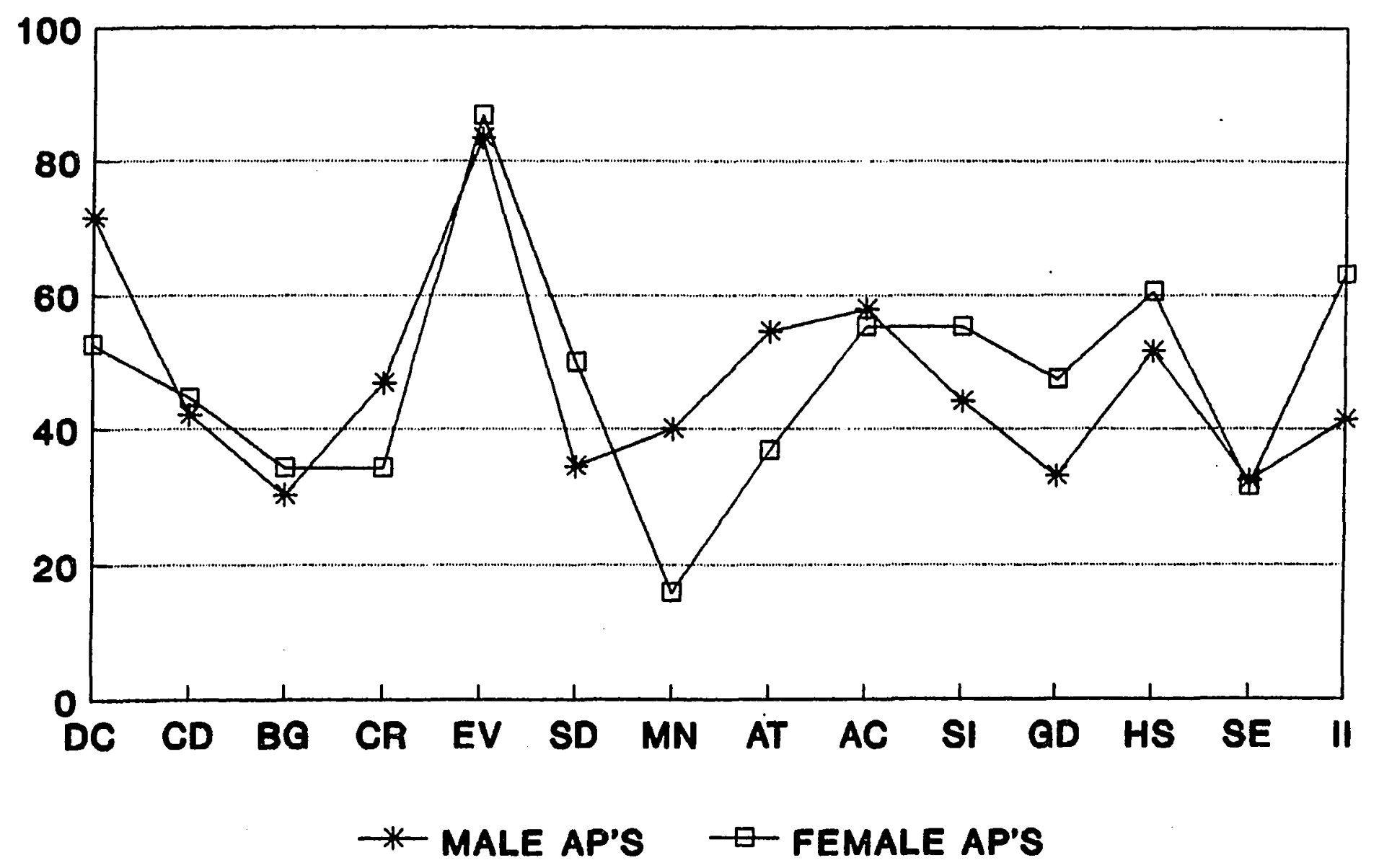

Figure 9. Differences in the assignments of male and female assistant principals. 
and those who had spent more than three years as assistants. Principals who spent less time as assistants had a mean score on the TRAINING index of $34.60 \quad(n=53)$ compared to that for principals who were assistants for a longer time, 42.64 $(n=73)$. With $d f=124$, a $t$-value of -2.66 was significant $(p=.009)$. Thus, the shorter the time spent as an assistant, the less value awarded overall to the assistant principalship as a training ground.

A detailed analysis of this difference is presented in Figure 10 which compares the percentage of principals giving high ratings and spending three years or less as assistants with the percentage of principals giving high ratings and spending four years or more as an assistant principal. The differences between the two groups of principals are spread fairly evenly over all fourteen areas of responsibility with the exception of budget (BG), evaluation (EV) and maintenance $(\mathrm{MN})$.

A second means by which past experience affects current perception can be seen in the way the length of time principals spent as assistants influenced the length of time they recommended assistants should spend in that position. Principals' were asked to recommend an appropriate length of time, three years or less or four years or more, for assistants to remain in that position before promotion to the principalship. This rating was then crosstabulated with the length of time each principal had spent as an assistant. 


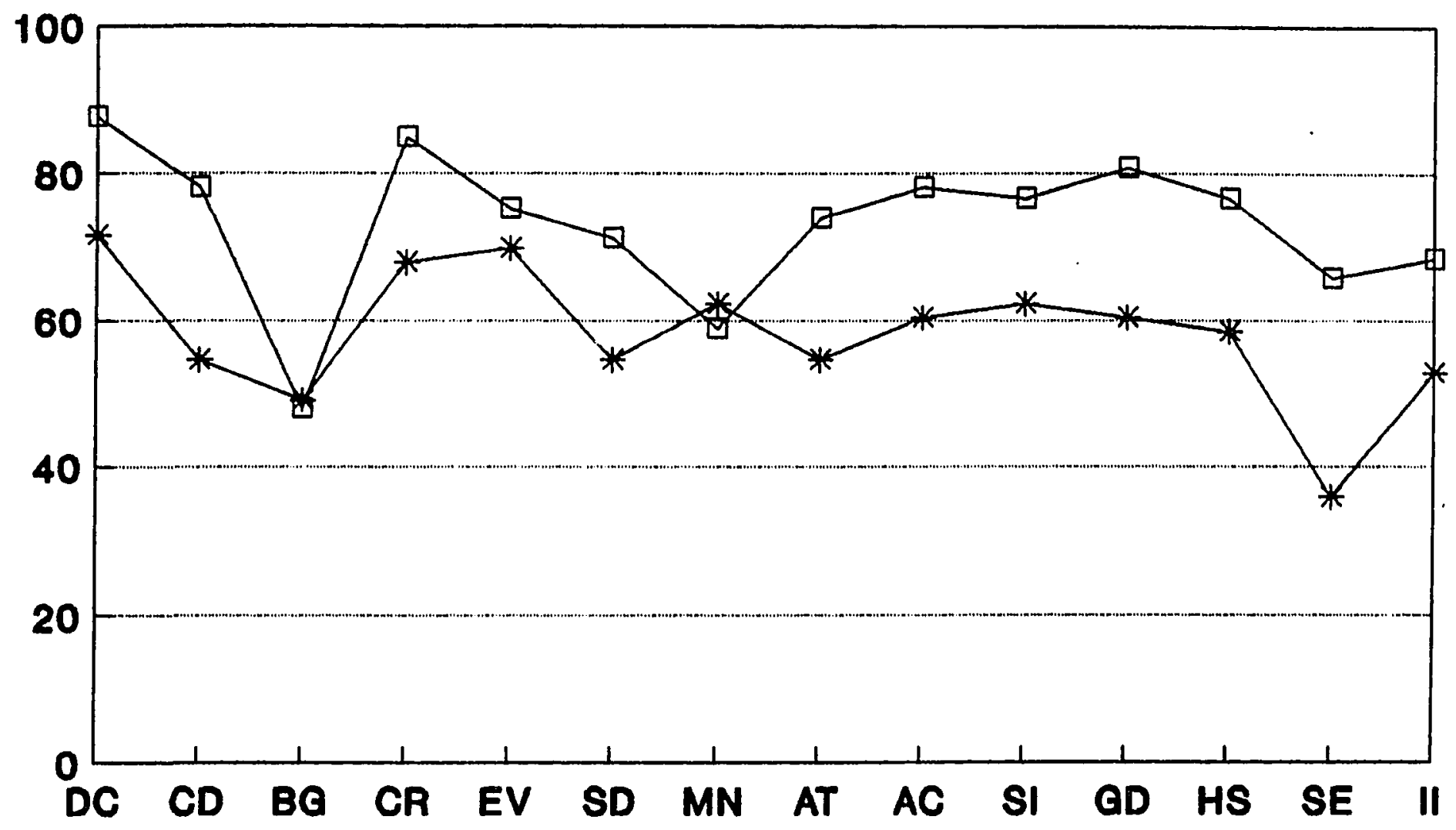

* 3 YRS OR LESS — OVER 3 YRS

Eigure 10. Effect of experience as assistant principal on principals' perceptions of training. 
The results showed principals tended to recommend a length of time that was commensurate with their own past experience. Sixty-eight percent of principals who had spent three years or less as assistants recommended this length of time as ideal, while $79 \%$ who had spent four years or more recommended this time period (Chi-square $29.05, d f=1$, $p=.0000)$.

\section{Experience as principal}

It was hypothesized that principals' training-value ratings would be influenced by the length of time they had been principals. Thus the mean TRAINING index score for principals who had been in their position three years or less was compared to that for principals on the job four years or more. Principals who had been in their position four years or more scored significantly higher on the TRAINING index (mean $=43.88, n=7 \overline{7})$ than those in the position a shorter time (mean=34.83, $n=58 ; t=-3.16$, d $f=133, p=.002)$.

Figure 11 analyzes the differences between these two groups area by area. The figure demonstrates that with the exception of maintenance (MN), a larger percentage of principals with four years or more in their current position consistently rated each area, somewhat to extremely valuable'. 


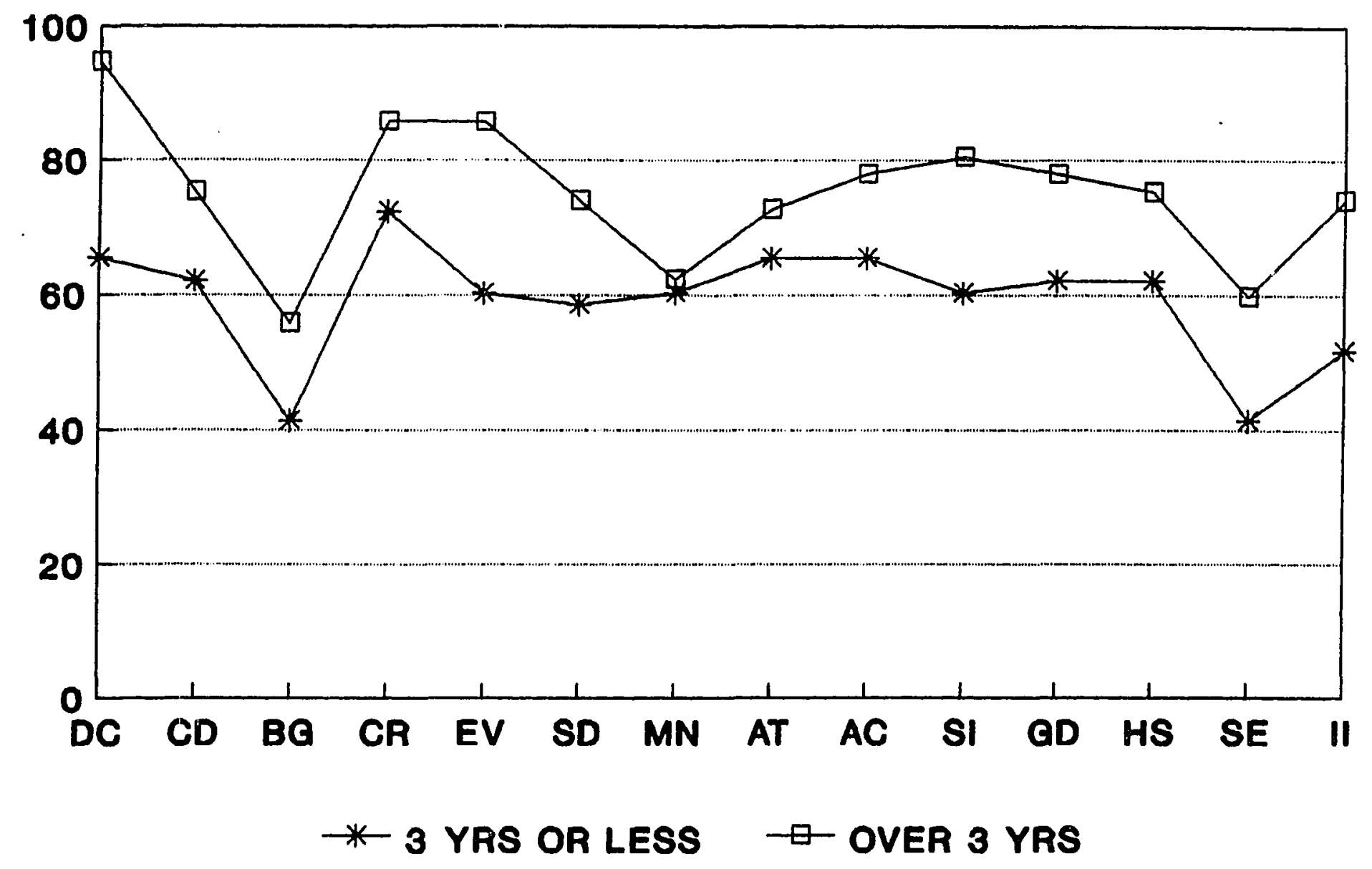

Figure 1.1. Elfect of experience as principal on principals' perceptions of training. 
Number of Assistant Principals Supervised

The size of staff supervised by the principal was also thought to affect his or her ratings of the training-value of each area. Thus principals who supervised staffs with one or no assistant principals were contrasted with those who supervised two or more assistants. The resulting t-test showed that principals supvervising two or more assistants had a higher mean score on the TRAINING index $(44.31, n=61)$ than those who supervised one or none $(35.88, n=i 6 ; t=-2.99$, $\mathrm{df}=135, p=.0031$.

Figure 12 analyzes these differences in detail. is before, this graph plots the percentage in each group rating an area 'somewhat to extremely valuable'. The figure demonstrates that principals supervising two or more assistants consistently rated each area'somewhat to extremely valuable' in greater numbers than those supervising one or no assistants. This parallels the views of assistant principals that the training of assistant principals in schools with more than one assistant is perceived as more valuable than for those with a smaller staff size.

\section{Gender}

A fourth factor believed to affect principals, ratings of training value was gender. Until recently, the principalship has been largely a male domain. It was 


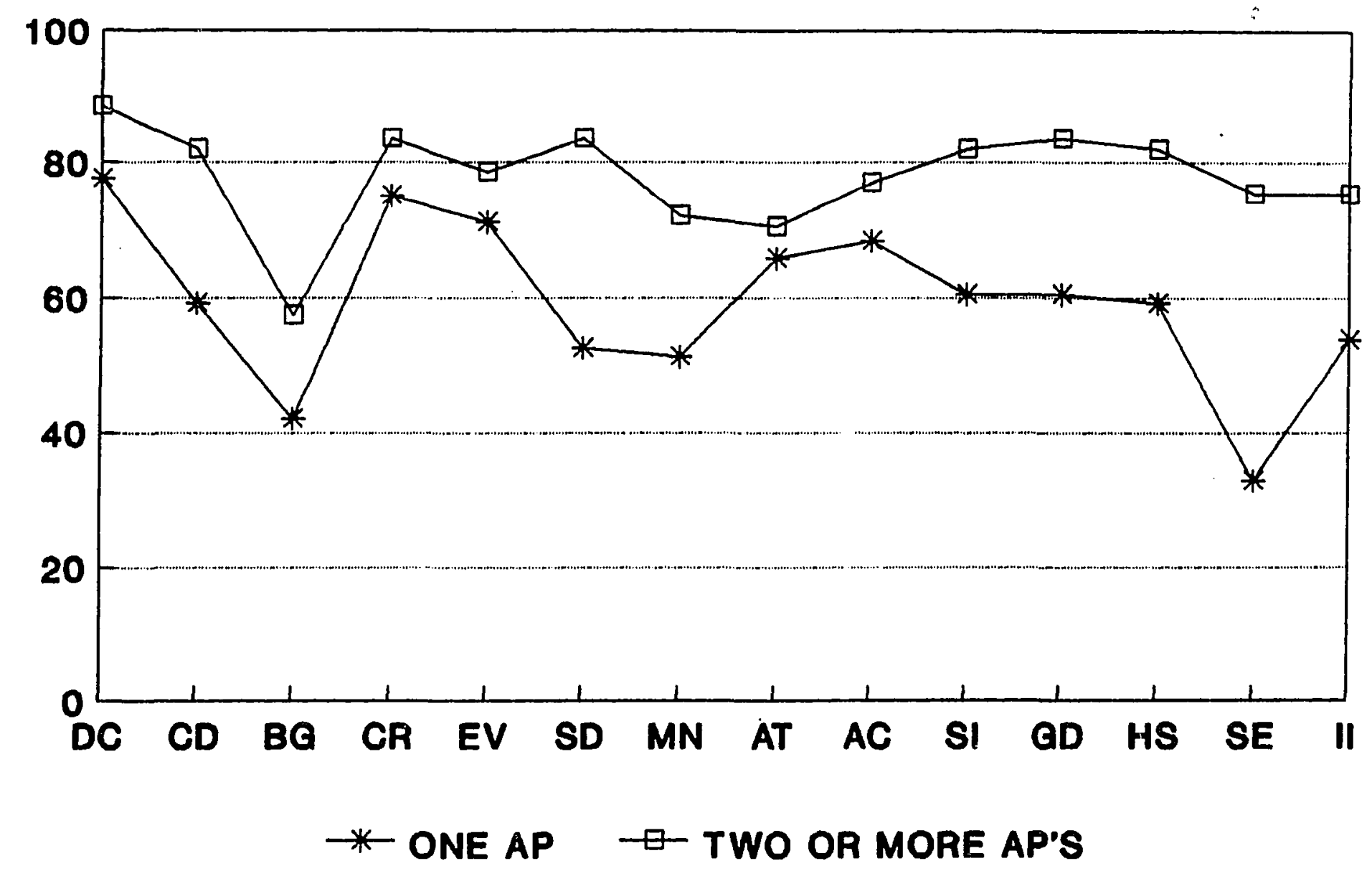

Figure 12. Effect of staff size on principal's perceptions of training. 
hypothesized that female principals might differ considerably in their perceptions of the assistant principalship as a training ground. To test this belief, a t-test was computed to compare male and female principals' mean scores on the TRAINING index. Female principals rated the overall training value of the assistant principalship significantly lower (mean=29.38, $n=13$ ) than their male counterparts (mean=40.86, $n=125)$. With df $=136$, the resulting $t$-value of 2.37 was significant at the .019 level of probability.

As in past analyses, area differences were evaluated graphically. The results of this comparison are illustrated in Figure 13 which plots the percentage of male and female principals rating each area 'somewhat to extremely valuable'. With the exception of two areas, curricuium development (CD) and special education (SE), female principals gave iower ratings to $\therefore l$ the areas of responsibility. Therefore, male principals placed more value on the areas of responsibility as a training ground.

\section{FACTORS AFFECTING THE PERCEPTIONS OF PRINCIPALS AND ASSISTANTS: AN INTERACTION EFFECT BETWEEN GROUP MEMBERSHIP AND GENDER}

A comparison of the graphic analyses of the eifect of gender on the respondents' ratings, especiaily in Figures $T$ and 13 , suggests that sender influences the ratings of principals and assistants differently. That is, female 


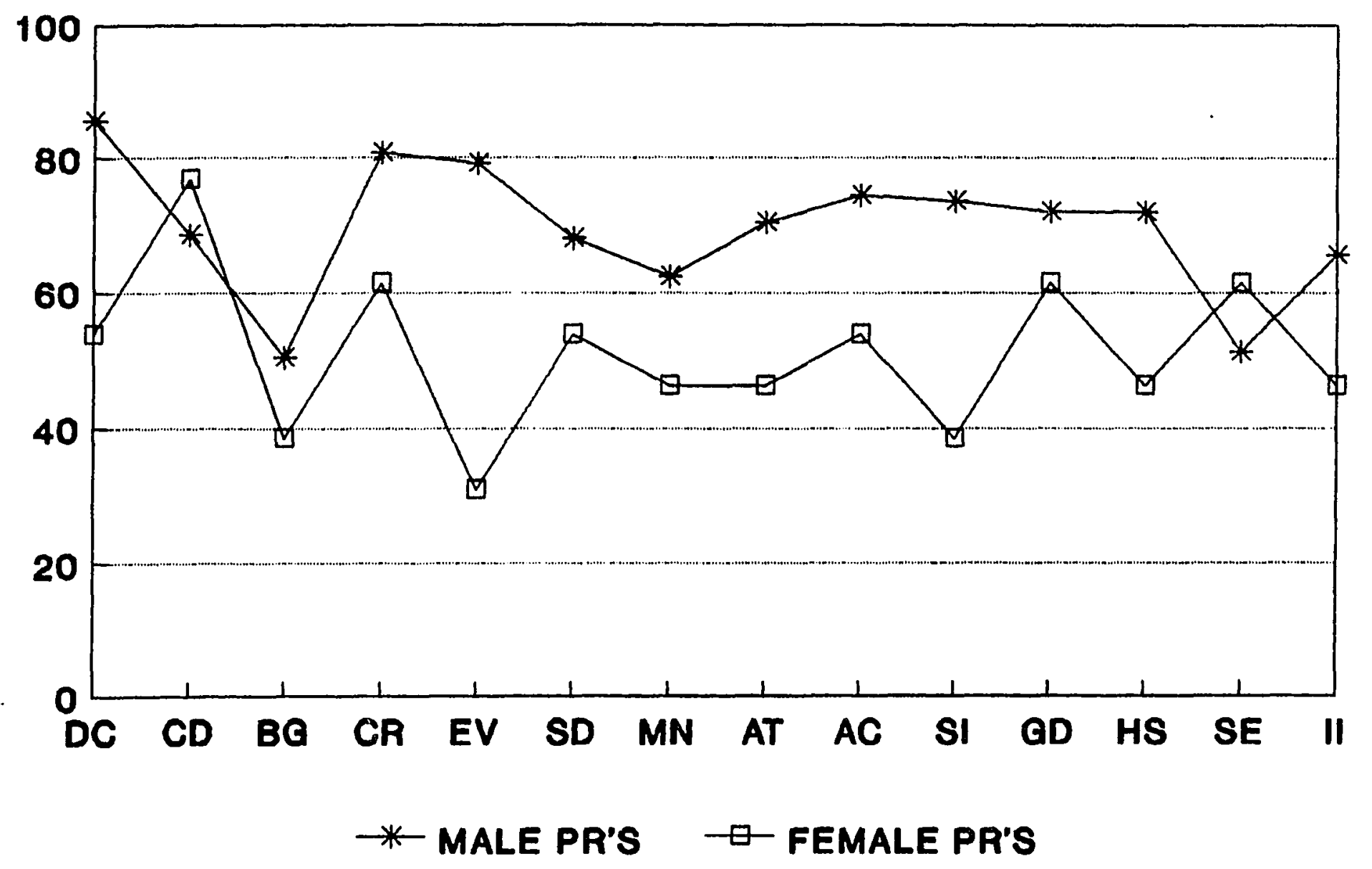

Figure 1 13 . Perceived differences in the value of training index items. 
assistant principals rated each area 'somewhat to extremely valuable' in higher proportions than male assistants. But for female principals the reverse is true; they rated each area 'somewhat to extremely valuable' in lower proportions than male principals. This observation suggests that group membership interacts with gender to influence the respondents' ratings of the value of assistant principal training. To test this observation further, a two-way analysis of variance was computed to learn if such an interaction was statistically significant. Independent variables in the analysis were group membership and gender. The dependent variable was the TRAINING index. The results of this analysis are presented in Table IV. The table indicates that while group membership and gender are taken as single main effects, only group membership shows a significant difference in mean TRAINI:G index scores. However, when group membership and gencer are considered as a two-way interaction term, the result is highly significant and suggests that gender influences the ratings of principals and assistants differently.

A comparison of the four group means on the TRAINING index suggests the source of the interaction: Male assistant principals were found to have a mean TRAINING index score of 46.12 while male principals had a mean of 40.86 . Female assistant principals were found to have a mean of 50.63 , 
TABLE IV

AN EXAMINATION OF THE INTERACTION BETWEEN

GROUP MEMBERSHIP AND GENDER ON THE

PERCEPTION OF TRATNING VALUE

USING ANALYSIS OF VARIANCE

\begin{tabular}{|c|c|c|c|c|c|}
\hline $\begin{array}{l}\text { SOURCE OF } \\
\text { VARIAT ION }\end{array}$ & $\begin{array}{r}\text { SUM OF } \\
\text { SQUARES }\end{array}$ & $\mathrm{DF}$ & $\begin{array}{l}\text { MEAN } \\
\text { SQUARE }\end{array}$ & $\mathrm{F}$ & $\begin{array}{l}\text { SIGNIF. } \\
\text { OF F }\end{array}$ \\
\hline GENDER & .013 & 1 & .013 & .000 & .993 \\
\hline \multicolumn{6}{|l|}{ GROUP } \\
\hline MEMBERSHIP & 4059.950 & 1 & 4059.950 & 23.903 & .000 \\
\hline \multicolumn{6}{|c|}{$\begin{array}{l}\text { TWO-WAY } \\
\text { INTERACTION : } \\
\text { GENDER \& GROUP }\end{array}$} \\
\hline & 2165.304 & 1 & 2165.304 & 12.748 & .000 \\
\hline $\begin{array}{l}\text { MEAN SQUAREI } \\
\text { ERROR }\end{array}$ & 53843.614 & 317 & 169.854 & & \\
\hline
\end{tabular}


while the mean for female principals dropped to 29.38 . The interaction effect is shown graphically in Figure 14 . Femile assistant principals on average gave higher ratings on the fourteen areas comprising the ThAINiNG index than did male astistants, whereas the reverse is true for principals where fomale principals on aterage gavo ioner ratings.

A dolailod andysis comparing the proportions of malc Hincipals and assistants rating cach area 'somentat to extremely 'aluable' is presented in Figure 15 . Figure 16 presents a comparable analysis for female assistants ard principals. What can be observed in the two figures is a much greatcr similarity ir the male ratings than those provided Ly females. Evidontl, the ratings of female respondents were more influenced by their sroup membership as assistant principal or principal tinan those provided by males.

SLIMMARY

Survers from 323 assistant principals and principals who nere members in the confederation of oregon schooi Administrators were analyzed statistically to ansier three research questions:

1. Do principals and assistant principals differ in the extent to which they perceive the assistant principalship as an adequate training ground for the principalship? 


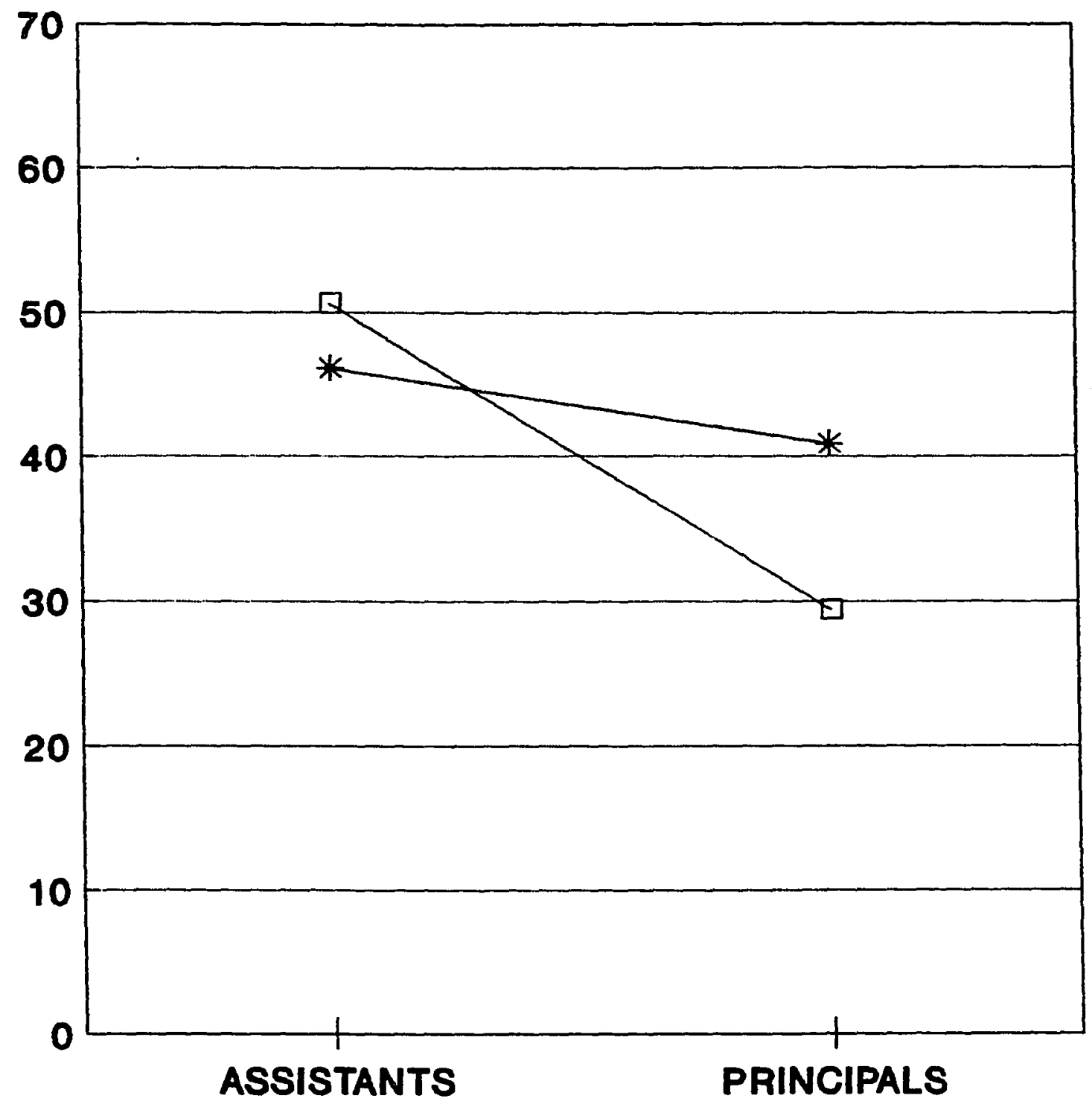

* MALES - FEMALES

Figure 14. Comparison of mean training scores for male and female assistants and principals. 


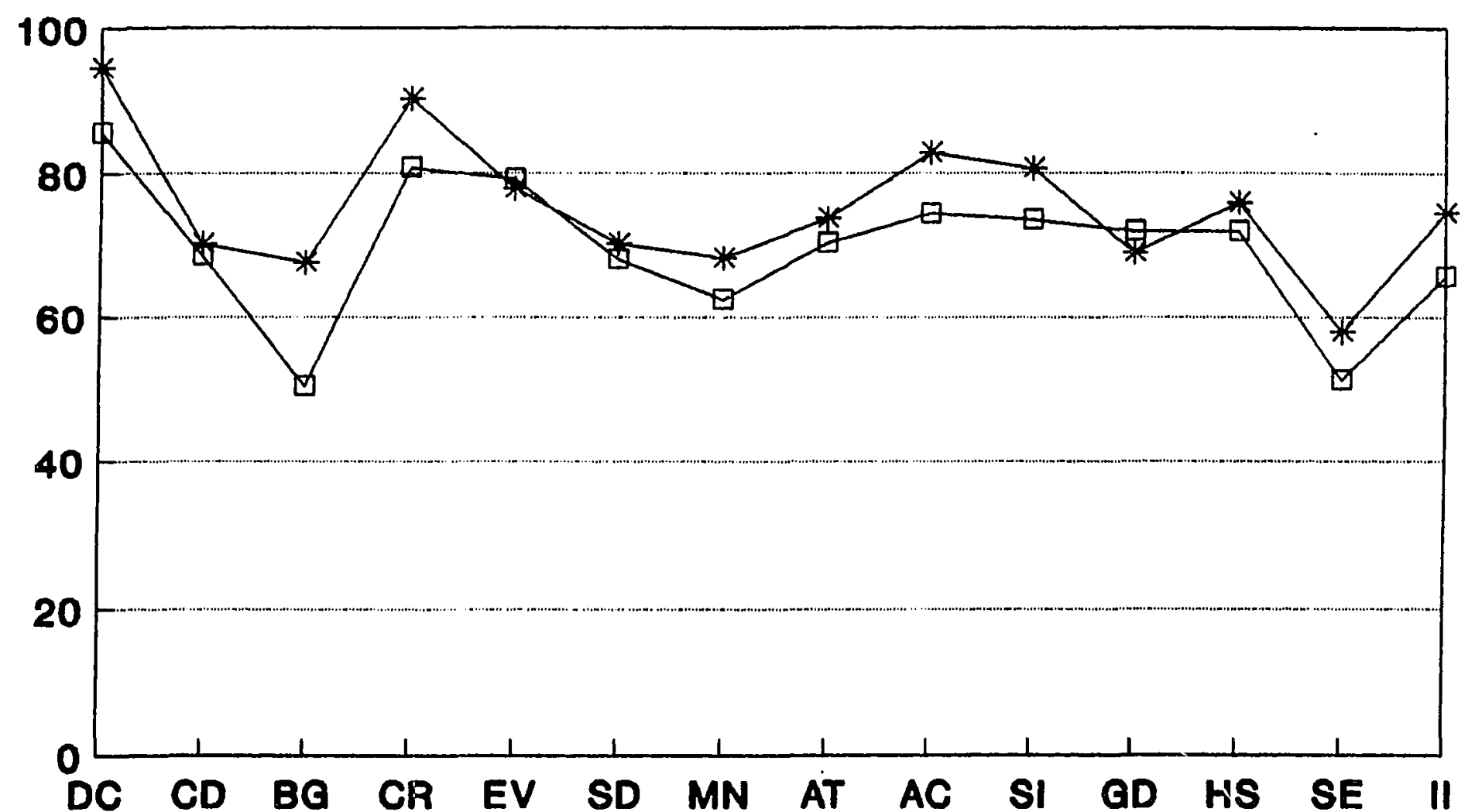

* male ASST. —- MALE PRIN.

Figure 15. Differences in perceptions of

training by male assistant.s and principals. 


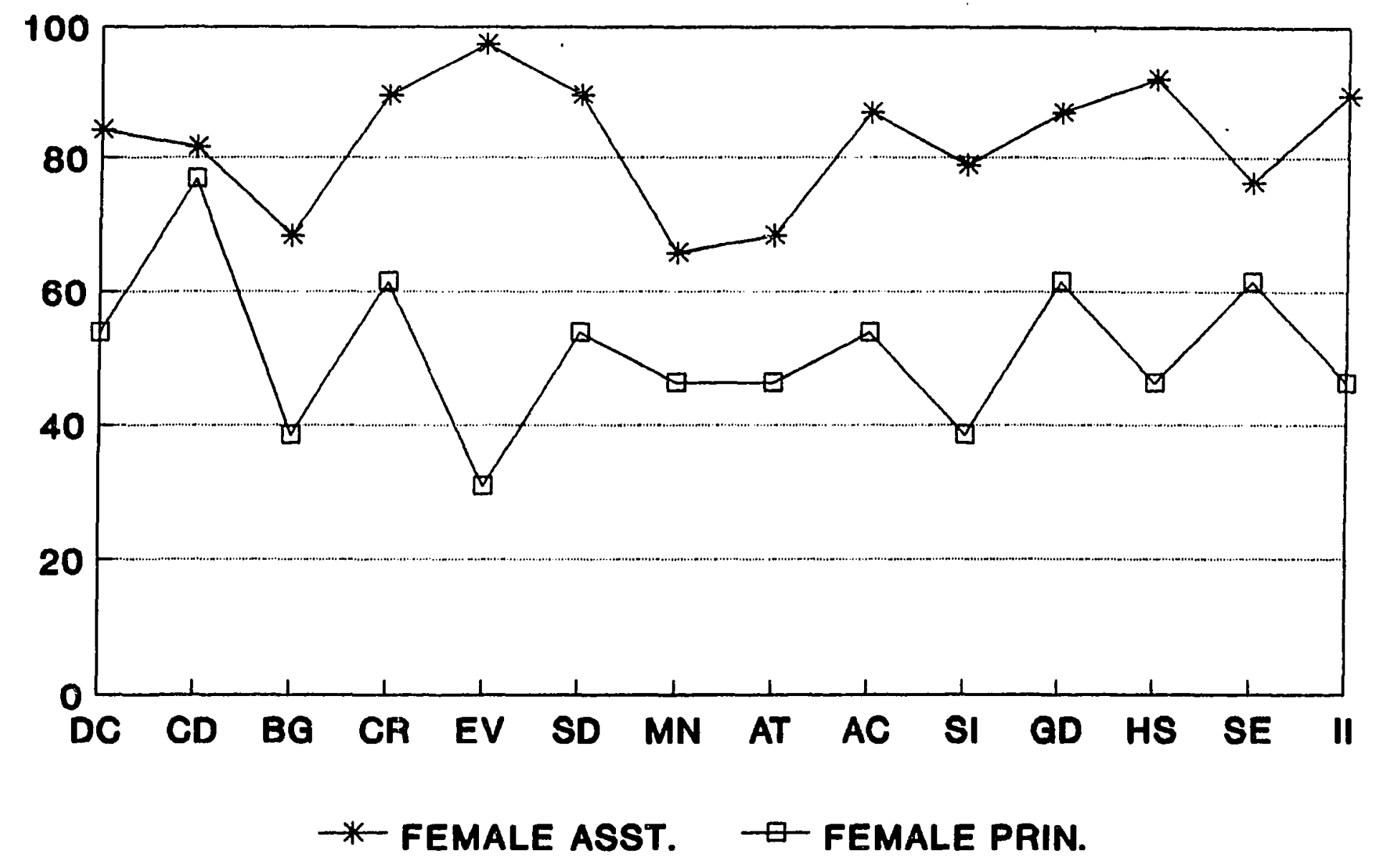

Fi fure l.j. Diflerences in perceptions of l.raining by female assistants and principals. 
2. What factors affect the perceptions of assistant principals?

3. What factors influence the perceptions of principals?

The major dependent variable used in the analyses performed to answer these questions was an index of overall ratings of the value of training. It was computed by summing the ratings of fourteen areas of responsibility. The six category rating scales were then reduced to two categories for use in graphs and to enhance interpretaion.

Comparisons of assistant principals' and principals' scores showed they differed significantly on their ratings of training value. Further analysis demonstrated a number of factors influenced the ratings and may account for the differences between assistants and principals.

When the factors affecting the assistant principais' ratings were assessed, two characteristics of assistants, staff size and gender, were found to significantly affect their ratings. There were no significant differences when assistants were grouped by their belief that the assistant principalship tias a satisfactory career goal in its own right.

Four factors were found to influence the ratings of principals: the length of their experience as assistant principals; the amount of time they had been principals, the 
number of assistant principals they currently supervised, and their gender.

Taken together, gender and group membership, were found to interact in their influence of the respondents' ratings of the training value of the assistant principalship. 
CHAPTER $\vartheta$

SUMMARY AND CONCLUSIONS

Although the assistant principalship has been an important part of American secondary schools for over thirty years, the educational establishment has yet to arrive at a formal definition of the assistant principal's role in that institution. Researchers have tended to find the assistant in a role defined by procedures. At the same time, they have called for a new definition of the assistant based on policy-making activities. This outcome has had several important consequences, not the least of which has been failure to provide formal guidelines for training assistants in their role and preparing them for future administrative assignments.

In their attempt to remediate these problems, a number of educational researchers have begun to rely on two themes that have emerged from the educational literature. The first focuses on new attempts to define the role of the assistant principal in investigations of the daily life of running the secondary school, i.e., in evaluating the potential of the assistant principal's position as a training ground. The rationale for this approach grows out of the idea that if the worth of the position as a training 
ground can be identified, the identification may lead to a better definition of the assistant principal's role. The second theme stresses the role of the principal in shaping this training ground. In combination, these themes suggest the usefulness of assessing how each administrator, the assistant and the principal, views the assistant principalship as a training ground.

This study was cast in that mold. It has investigated the relationship between fourteen areas of responsibility connected with secondary school administration and the role of the assistant principal in meeting them. Unlike previous studies, it has emphasized, not the areas themselves, but the perceptions of principals and assistants who rated the value of each area as a training ground for the principalship. By classifying the areas perceived to be most valuable for training, the study contributes to the emerging definition of the assistant principalship. Also, by explaining the relationship between the administrators' backgrounds and their influence on the ratings given, this study has attempted to account for the factors that affected the respondents' perceptions.

The study was organized around three research questions:

(1) Do principals and assistant principals differ in the extent to which they perceive the assistant 
principalship as an adequate training ground for the principalship?

(2) What factors affect the perceptions of assistant principals?

(3) What factors influence the perceptions of principals?

In order to address these questions, secondary school administrators who were members of the Confederation of Oregon School Administrators (COSA) were surveyed. They rated fourteen areas of responsibility for their training value and for the extent to which assignments to the areas were made on the basis of gender stereotyping. In addition, the areas to which the respondents were currently assigned were reported. The respondents also supplied background information concerning the years of experience in their current position and size of the administrative staff of which they were a part. Of the $45 t$ members survered, 373 returned completed questionnaires, yielding a response rate of $71 \%$. Assistant principals comprised $57 \%$ of the sample, while principals comprised $43 \%$. Females comprised $16 \%$ of the sample and males $84 \%$.

Major findings suggest that while principals and assistants differed in the amount of value they awarded each area, they consistently identified the same areas as valuable. Assistants, perceptions were found to be influenced by staff size and gender. Principals' perceptions 
were related to their length of tenure as assistant principals, how long they had been principals, number of assistant principals they supervised, and gender. This chapter summarizes those findings, describes the implications of the study, and makes recommendations for future research.

\section{SUMMARY OF FINDINGS}

This section summarizes the substantive findings of the study. It addresses each research question in turn.

\section{Comparison of Principals' and Assistant Principals'} Perceptions

In order to answer the first research question, the perceptions of principals and assistants were compared. The differences in the overall value placed by principals and assistants on the assistant principalship as a training ground were examined. When queried in general about the preparation value of the assistant principalship, there were no differences in principal and assistant perceptions; both perceived the assistant principalship as highly valuable (see Figure 3 ).

In contrast, when ratings of the fourteen areas were made separately and then summed, assistants and principals were found to differ significantly. A detailed analysis of these differences made on an item-by-item basis (see Figure
4) showed that the
difference
was
a consequence of the 
fact that more assistant principals than principals perceived the fourteen areas as good preparation for the principalship.

$\dot{S}$ ix areas were identified as most valuable in preparing the assistant to move into the principal's position by the two groups of administrators. Principals judged discipline, community relations, teacher evaluation, activity supervision, and guidance and counseling as the most valuable areas of responsibility for training. Assistant principals perceived the same areas as most valuable with the exception of guidance and counseling for which they substituted school improvement. (See Figure 4.) If all six areas are taken into consideration, and classified as either procedure-based or policy-based they are evenly divided between the two categories. Discipline, activity supervision, and guidance and counseling can be classified as procedural while community relations, teacher evaluation and school improvement emphasize policy making. Although each area has some elements of both, this classification scheme suggests that principals and assistants recognize the need for assistants to be involved in both categories of activity.

\section{Factors Influencing tssistant Principals' Perceptions}

The second research question asked what factors influenced the perceptions of the assistant principals. Two 
factors were found to significantly influence their perceptions. They were staff size and gender.

Assistants from schools with two or more assistants tended to rate the value of the fourteen areas higher. This finding may be explained by the fact that assistant principals in schools with larger staff sizes tended to be assigned to policy areas at a higher frequency (see Figure 6). When the frequency of assignments differed, assistant principals in schools with a higher staff size were more frequently assigned to curriculum development, hiring and selection, and improvement of instruction. At the same time, assistants from schools with low staff size were more frequently assigned to athletic supervision and activity supervision. This finding suggests that schools with larger staffs mav have more policy-oriented training grounds for their assistant principals.

The second area found to significantly influence the assistant principal perceptions was gender. Although there were some areas (discipline, athletic supervision, maintenance, and improvement of instruction) where male and female assistants were assigned at a greater rate than expected by chance, there was no difference between their ratings of the extent to which assignments were made on the basis of gender stereotyping. Of the areas where differential assignment was shown to exist, females were more frequently assigned to the policy area of improvement 
of instruction while males were more frequently assigned to the procedural areas of discipline, athletic supervision and maintenance (see Figure 9 ).

$\dot{A}$ comparison of male and female ratings of the worth of each of the fourteen areas showed significant differences in their perceptions. These differences were in large part attributable to the fact that more female assistant principals rated the policy areas of curriculum development, teacher evaluation, staff development, hiring and selection, and improvement of instruction higher than their male counterparts (see Figure 8 ).

\section{Factors Influencing Principals' Perceptions}

Research question three asked what factors influenced the principals' perceptions. There were four factors in all that were found to be significantly influential: amount of time as assistant principals, length of time as principals, number of assistants supervised, and gender.

The first was length of time principals spent as assistant principals. Principals who had spent over three years as assistants tended to rate the assistant principalship as valuable more often than those who were assistants three years or less (see Figure 10). This result suggests that greater time spent by principals as assistants may have enhanced their appreciation of the ralue of the assistant principalship as a training ground. 
The second factor was length of time spent as a principal. The pattern for these ratings was similar to that discussed above. Respondents who had been principals more than three years tended to rate the fourteen areas higher than those who had been principals three years or less (see Figure 11). Taken together, these two results may lead to the conclusion that principals who placed more value on the assistant principalship are more likely to work within the teamwork approach and devise new ways to shape the assistant principalship as a training ground.

The size of the staff supervised by principals was also shown to influence their perceptions. Principals supervising a staff with two or more assistants tended to rate all fourteen areas more valuable (see Figure 12). One explanation for this result is suggested by the relationsinip between staff size and student population. The larger the population, the greater the number of tasks for administrators. Thus, if staff size is a surrogate measure for the size of student population, then it also measures the number of tasks a principal must face. These findings may point to the fact that principals with more tasks come to appreciate the abilities of their assistants and therefore the value of the assistant principalship as a training ground.

As was the case with assistant principais, gender was also shown to affect the principals perception of the 
assistant principalship as a training ground. Male principals consistently rated the value of the large majority of the areas higher than their female counterparts (see Figure 4.13). Gender differences are complicated by their relationship with group membership. These indings are described in the following section.

Interactive Influence of Group Membership and Gender on Perceptions

The pattern of male principals rating the value of assignments higher than female principals constituted a reversal of that seen for male and female assistants and lead to a more complex analysis of the relationship between the respondents' group membership as principal or assistant, their gender, and the ralue placed on the assistant principalship as a training ground. A multivariate analysis which simultaneously assessed the effects of group membership and gender on the respondents: ratings uncovered the fact that female assistants and female principals differed substantially in their ratings of the value of the assistant principalship as a training ground. Whereas male principals and assistants were highly similar in their ratings, female principals rated the fourteen areas significantly lower than femaie assistants isee Figure 161 .

These results lead to the speculation that maie and female principals may reach the principalship by a different 
path. It also suggested that promotion to principal may have changed the female principals' perceptions of their training. This outcome could also affect the way principals adopt the concept of teamwork in the school-site training of the assistants they supervise.

The size of the subpopulations based on gender within the sample reflected the distribution of males and femaies who actually held administrative positions in secondary schools in Oregon. However, it would be useful to replicate these results, since the number of female principais in this sample was small $(n=13)$.

\section{IMPLICATIONS OF THE FINDINGS}

The study has addressed the problem of a definition for the role of assistant principal and has investigated similarities and differences in how principals and assistants perceived the value of the assistant principalship as a training ground. The findings showed that both principals and assistants had identified six areas that were rated most valuable for training and, more importantly, that the areas chosen demonstrated the respondents' belief that the role of the assistant principal should be a blend of procedural and policy-making duties. Other investigators (cf., Greenham, 1972; Smith, 1984; Greenfield, 1985; Black, 1980; Reed, 1984; Hentges, 1976) have stressed either a procedural or policy-making function 
for the assistant. This investigation suggested that principals and assistant principals themselves were placing greatest value on, and would operationally define the role of the assistant as, a combination of both policy and procedure.

It was important to note that principals concurred with assistants' perceptions of the most valuable areas. This observations suggested a successful future for the teamwork concept in making day-to-day life in the secondary school a more adequate training ground for assistant principals. When the question was posed in general, there was no significant difference in the groups' perceptions of the assistant principalship as a training ground Isee Figure 3). When they did differ in their ratings of the value of the fourteen areas, it was because fewer principals than assistants gave high ratings. It was not because they rated different areas most valuable (see Eigure 4 ).

These findings have implications for the future definition of the assistant principaiship and improved training for assistants because they showed that principais believed in the value of the assistant principalship as a training ground. Thus, they also suggest the feasibility of combining the leadership of the principal and the concept of teamwork in both the definition and training of assistants. Since both groups concurred that a combination of policy and procedure best defined the assistant principal's 
role, principals and assistants may be more prepared than they realize to implement the recommendations made recently ir the newsletter of the National Association of Secondary School Principals:

Perhaps the most important concept is involving the assistant principal in policy making, planning, and daily decision making with regard to school administration. Since the assistant principal's authority to act must be delegated and supported by the principal, a real sharing of responsibility by means of an administrative team built on collegial relationships is essential (November, 1988, p. 11 .

\section{RECOMMENDATIONS FOR FUTURE RESEARCH}

There are several research questions that could usefully be answered in new research efforts.

1. A new study could determine whether or not school size affects administrators' perceptions more dramatically than could be shown in a sample with as inucin diversity as that employed here. Staff size was shown in this investigation to significantly affect the respondents' perceptions. Therefore, it might be useful to comparatively survey samples of small and large schools. Such research could uncover the fact that the role of the assistant principal should vary according to school size.

2. Replication of this research also presents an opportunity to seek out and include a larger number of female administrators. The findings reported here could be 
reinforced by increasing the number of female administrators' perceptions analyzed.

3. These findings suggested that female principals significantly differed from female assistant principals in their ratings of the assistant principalship as a training ground. While it would be useful to confirm these findings with a larger sample, it would also be informative to account for these differences by comparing male and female principals and female principals and assistants along a number of dimensions. It would be valuable to know if male and female principals moved into their positions by different paths. Were they assistant principals for different lengths of time? Have they been principals for comparable lengths of time? Additionaliy, such research could ask what factors account for the apparent change in the way female assistants and principals value the assistant principalship as a training ground.

4. An area of concern in the literature was job dissatisfaction among assistant principals le.g., Black, 1980). These findings have shown that male assistants are sometimes given more procedural assignments than female assistants. These observations present an opportunity to confirm the notion that a combination of procedural and policy making assignments would enhance job satisfaction. This issue could be addressed by answering the question: 
Do assistants with a combination of procedural and policymaking assignements have greater job satisfaction?

5. The TRAINING index proved to be a useful tool in determing perceptions of the administrators as to the value of each of the 14 areas of assignment. Additional research could utilize this idea in determining how administrators view the assignments as to the value by procedure vs. policy-making classifications by employing similar tools designed as PROCEDURE and POLICY indexes. Such an investigation would give administrators, a more in-depth analysis of the areas of responsibility and assist them in revising assistant principal job descriptions to further promote professional growth within the assistant principalship.

6. The results indicated that assistant principals who had served in the assistant principalship for over three rears tended to place more value on the Fosition as a training ground. In a similar rein, principais who had served in the principalship for over three rears tended to place more value on the assistant principalship as a training ground. It would be interesting to determine if at some point in their professional careers this perception changes. Do assistant principals or principais have the view of the assistant principalship after having served in their respective role for over five years, over seven years, etc? Is there a certain point in one's career after having 
served in the assistant principalship a rumber of raas that. you no longer piace as much value on the position as a training ground?

\section{CONCLUSTON}

The assistant principal has become an integral part of secondary school administration over the last thirty ycars. let as the education system has evolved, the role of the assistant principal as described in the literature has remained constant. Recent research has tried to explore the assistant's role in order to enhance the value of the assistant principal's efforts. However, without continued focus on the development of the assistant's role and its evolution in the decades to come, the edicational establishment will not effectively be utilizing what may be ore of its most valuable resources. This study has focused on refining the definition of the assistant principal in the hope that the value of the position in the ongoing deveiopment of secondary school administration will not be overlooked. 
REFERENCES

Austin, D. B., \& Brown, H. L., Jr. (1970). Report of the assistant principalship. volume 3: The study of the secondary school principalship. Washington, D.C.: National Association of Secondary School Principal. (ERIC Document Reproduction Service No. ED 053499 )

Barratt, T. K. (1955). Assistant principals. School Board Journal, 130 , p. 56 .

Bates, R. C. \& Shank, J. G. (1983, April). The associate principalship: a better, more effective way to manage schools. iSSP Bulletin, $\underline{6} 7(462)$, pp. 111-114.

Bilboa, J. B. (1980). A study of the inservice needs of secondary assistant principals in southwestern Idaho. Dissertation Abstracts International. (University Microfilms No. ADG 81-00,380)

Black, A. B. (1980, May). Clarifying the role of the assistant principal. NASSP $\underline{\text { Bulletin, }} \underline{64}(+36)$, pp. 3339 .

Bordinger, D. L. (1973, October). Making the assistant principalship a career position. VASSP Bulletin, $\underline{\mathbf{5} T}$, pp. $10-15$.

Bortner, D. (1972). Public relations for pubiic schools. Cambridge, yS: Schenkman Publishing Co.

Brown, G. J., \& Rentschler, J. E. (19i3, October). Why don't assistant principals get the principalship? NASSP Bulletin, 5i, pp. 36-4i.

Burgess, L. (1972). The new assistant principal--key person in the principal's team. Anaheim, CA: Paper presented at the National Association of Secondary School Principals Annual Convention. (ERIC Document Reporduction Service No. ED 062 i17)

Burgess, L. (1973, October). Accepting the challenges of career development. NASSP Bulletin, ji, pp 48-52.

Burgess, L. (1976, April). The assistant principalship: where now? VASSP Bulletin, 60, pp. 6i-81. 
Carmines, E. G. \& Zeller, R. A. (1979). Reliability and validity assessment. Beverly Hills, CA: Sage Publications.

Clements, J. (1980, May). Enhancing the role of the assistant principal. NASSP Bulletin, 64, pp. 14-22.

Evans, D. (1986, January). Leadership misconstrued: the myth of 'super principal.' Thrust, 15(14), pp. 3i-39.

Fallon, B. V. (1974). Advice to the prospective assistant principal. NASSP Bulletin, $\underline{58}$, pp. $76-80$.

First, P. \& Carr, D. (1986, November/December). Do you still want to be principal? Thrust, $16(3)$, pp. 48-50.

Garawski, R. A. (1978, September). The assistant principal: his job and organizationai potency. Clearing House, $\underline{52}(1)$, pp. 8-10.

Gatti, R. D. \& Gatti, D. J. (1975). Encrclopedic dictionary of school law. West Nyack, Ni: Parker Publishing Company, Inc.

Gillespie, T. M. (1961). The assistant principai: status, duties, and responsibilities. National Association of Secondary School principals, 45 , pp. 5968 .

Gorton, R. (1987, October). Improving the assistant principalship: the principal's contribution. NASSP Bulletin, il, pp. 1-4.

Greenfield, w. D. (1985, November). Developing an instructional role for the assistant principal. Education $\underline{\text { Urban }}$ Society, $\underline{i 1}$, pp. 85-92.

Greenham, W. H. (1972, September). Who is the assistant principal? Explorations into an elusive roie. American Secondary Educaton, $\underline{2}(4)$, pp. 27-32.

Gross, R. A., Shapiro, M., \& Meehan, J. (1980, Yay). Principals and assistants--how the management team concept can succeed. ViassP Bulletin, $\underline{64}(+36)$, pp. 2628 .

Guthrie, J. W. \& Reed, R. J. (1986). Educational administration and policy. Englewood Cliffs, $\mathrm{iJ}$ : Prentice-Hall. 
Gutek, G. (1983). Education and schooling in america. Englewood Cliffs, $\mathrm{NJ}$ : Prentice Hall.

Hall, G. E. \& Guzman, F. (1984). Sources of leadersinip for change in high schools. Washington D. C.: National Institute of Education. (ERIC Document Reproduction Service No. ED 250815 )

Hamlen, B. R. (1983). The campus coordinator's role as technical assistant to the principal. Dissertation Abstracts International. (University Microfilms No. ADG 84-12, 0221

Hampel, Sister J. (1987, October). women administrators: networking for success. NASSP Bulletin, i1, pp. 44-45.

Hentges, J. T. (1976). A normative study of the assistant principalship in selected Minnesota secondary schools. Mankato state University: Educational Specialist Theses. (ERIC Document Reproduction Service No. ED $168 \quad 1+81$

Hess, F. (1986). Study of sexual stereotyping in job selection. Chicago, IL: A paper presented at the Annual Meeting of the Midwestern Educational Research Association. (University Microfilms No. ADG 86-16324)

Hess, F. (1985, November). The socialization of the assistant principal from the perspective of the local school district. Education and Erban Society, 18(1), pp. 93-106.

Howley, P. (1985, January). From the inside out--the assistant principaiship--changes, speculations offered. NASSP Bulletin, $59(477)$, pp. 88-92.

Hurley, L. (1965). The vice principal. NASSP Bulletin, \pm 9 , pp. $12-14$.

Jarrett, R. W. (1958, September). The activities of the assistant principal in secondary schools. The Bulletin of the National Association of Secondary School Principals, $\underline{42}$, pp. 28-32.

Kalla, M. M. (1983). A study of Kentucky secondary assistant principals: job responsibilities, importance, and satisfaction. Dissertation Abstracts International. (University Microfilms No. ADG 8402,9581 
Kelly, G. (198i, October). The assistant principalship as a training ground for the principalship. VisSP Bulletin, 71, pp. 13-18.

Kolb, D. A. (1984). Experiential learning: experience as the source of learning and development. Englewood Cliffs, NJ: Prentice-Hall.

Kriekard, J. A. (1985). A validation of competencies for the secondary school assistant principal (performance based). Dissertation Abstracts International. (University Microfilms No. ADG 85-14,333)

Kriekard, J. A. \& Norton, M. S. (1980, May). Using the competency approach to define the assistant principalship. NASSP Bulletin, $\underline{64}(436)$, p. 1-8.

London, L. (1985). Deveioping managers. San Francisco, CA: Jossey-Bass.

Long, C. M. (195i, February). Duties of secondary school vice principals. National Association of Secondary Schools Principals, $11(226)$, pp. 26-3i.

Manasse, A. L. (1982, March). Effective principals: effective at what? Principal, $\underline{61}(4)$, pp. 10-15.

Mazzei, R. (1976). What is a vice-principal? Clearing House, $\underline{ \pm 9}$, p. 319 .

McDade, T. E. (1981). Career path models for women administrators (Doctoral dissertaion, Arizona state Universitr, 1981 ). Dissertation tbstracts International, 8117175 .

YcDonald, P. S. (1981). An observational study of the workday of the urban high school assistant principal (Doctoral dissertation, Portland State University, 1981). Dissertation Abstracts International, 81207971 .

NcIntyre, K. E. (1988, November). How to increase the assistant principal's effectivenss. Iips for principals from NASSP. Renton, VI.

Michigan State Department of Education. (1985). The Michigan institute for educational management assessment center program. Lansing, Michigan. (ERIC Document Reproduction Service No. ED 253565 ) 
Norton. H. S. \& Kierkard, J. A. (1987, Octoberi. Real and ideal competencies for the assistant principal.

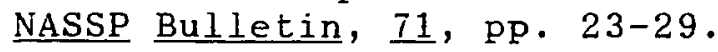

Norusis, M. (1988) SPSS/PC+V2.0 Base manual for the IBM PC/XT/AT and $\underline{P S / 2}$. Chicago, IL: SPSS, Inc.

Novak, B. J. (1963, June). Examining the role of the vice-principal. American School Board Journal, $146(6)$, pp. 19-20.

Nunnally, J. C. (1978) Psychometric theory. New York, NY: McGraw-Hill Company.

Panyako, D. \& Rorie, L. (1987, October). The changing role of the assistant principal. NASSP Bulletin, 71 , pp. 6-8.

Paus, G. S. (1970, February) The assistant principal. Oregon School Study Council Bulletin, $\underline{13}(6)$, pp. 1-29.

Peterson, K. D. (1985, March). Principals' work, socialization, and training: developing more effective leaders. Therov Into Practice, 25(3), pp. 151-155.

Peterson, K. D., Marshall, C. \& Grier, T. (1987, Octoberl. The assistant principals, academy: technical training and socialization of future leaders. NASSP Bulletin, i1, pp. 32-38.

Potter, J.M., Jr. (1980, May). Ten suggestions: enhancing the role of the assistant prircipal. NASSP Bulletin, $\underline{64}$, pp. 9-12.

Reed, D. B. (1984). The work of the secondary vice principalship: a fieid study. Dissertation Abstracts International. (Lniversity Microfilms No. ED-246 527 )

Roderick, L. (1986, February). Between us principals: working with assistant principals to achieve maximum value. NASSP Bulletin, 70 487$)$, pp. 91-94.

Smith, J. A. (198T, October). Assistant principals: new demands, new realities, and new perspectives. NASSP Bulletin, I1, pp. 9-12.

Smith, J. A. (1984). A comparative study of the role of the secondary assistant principal: new demands, new realities, and new perspectives. Dissertation Abstracts International. (University Microfilms No. ADG 84-24, 947) 
Turner, H. E. (1973, October). The VIP as a VIP. NASSP Bulletin, 57, pp. 53-62.

Valentine, J. (1980, May). Preparing vour assistant for the principalship. NASSP Bulletin, 64(436), pp. $40-43$.

webster, J. R. (1985). Case studies of women superintendents, assistant superintendents, secondary principals, and secondary assistant principals in the state of Maine. Dissertation Abstracts International. (University Microfilms No. ADG $85-17,434$ )

Weldy, G. R. (1979, May). Principals: what they do and who they are. NASSP Bulletin, 63, pp. 20-22.

Wells, P. C., Nelson, R. H., \& Johnsen, E. M. (1965).

The assistant secondary school principal. NASSP Bulletin, $\underline{49}$, pp. $15-22$. 
APPENDIX A

PILOT STUDY PARTICIPANTS 
Edison High School:

Jack A. Kennedy, Principal

Brian Garland, Assistant Principal

Bill Blankinship, Assistant Principal

Tony Lipold, Activities Director

Jim Buhman, Dean

Carla Rush, Dean

Fountain Valley High School:

Mike J. Kasler, Principal

Hal Gubernick, Assistant Principal

Wayne Mickaelian, Assistant Principal

Jim Lande, Assistant Principal

Mike Bryan, Activities Director

Derek Harrison, Dean

Carol Osbrink, Dean

Huntington Beach High School:

Gary D. Ernst, Principal

Leon Stoabs, Assistant Principal

Joanne Haukland, Assistant Principal

Darrell Stillwagon, Activities Director

Ron wootton, Dean

Tracy Brennan, Dean

Marina High School:

Dr. Ira Toibin, Principal

Jeannine Lucan, Assistant Principal

Jim Keating, Assistant Principal

Dave Thompson, Activities Director

Mark Attebery, Dean

Barbara Ryan, Dean

Ocean View High School:

John P. Myers, Principal

George Clemens, Assistant Principal

Shirley Pyle, Assistant Principal

Jim Staunton, Dean

Paul Zack, Dean

Westminister High School:

Robert A. Boehme, Principal

Ed Harcharik, Assistant Principal

Frank Paredes, Assistant Principal

Don Griffiths, Asctivities Director

Carolyn Stephenson, Dean

Rosemarie whitworth, Dean 
APPENDIX B

PILOT STUDY COVER LETTER 


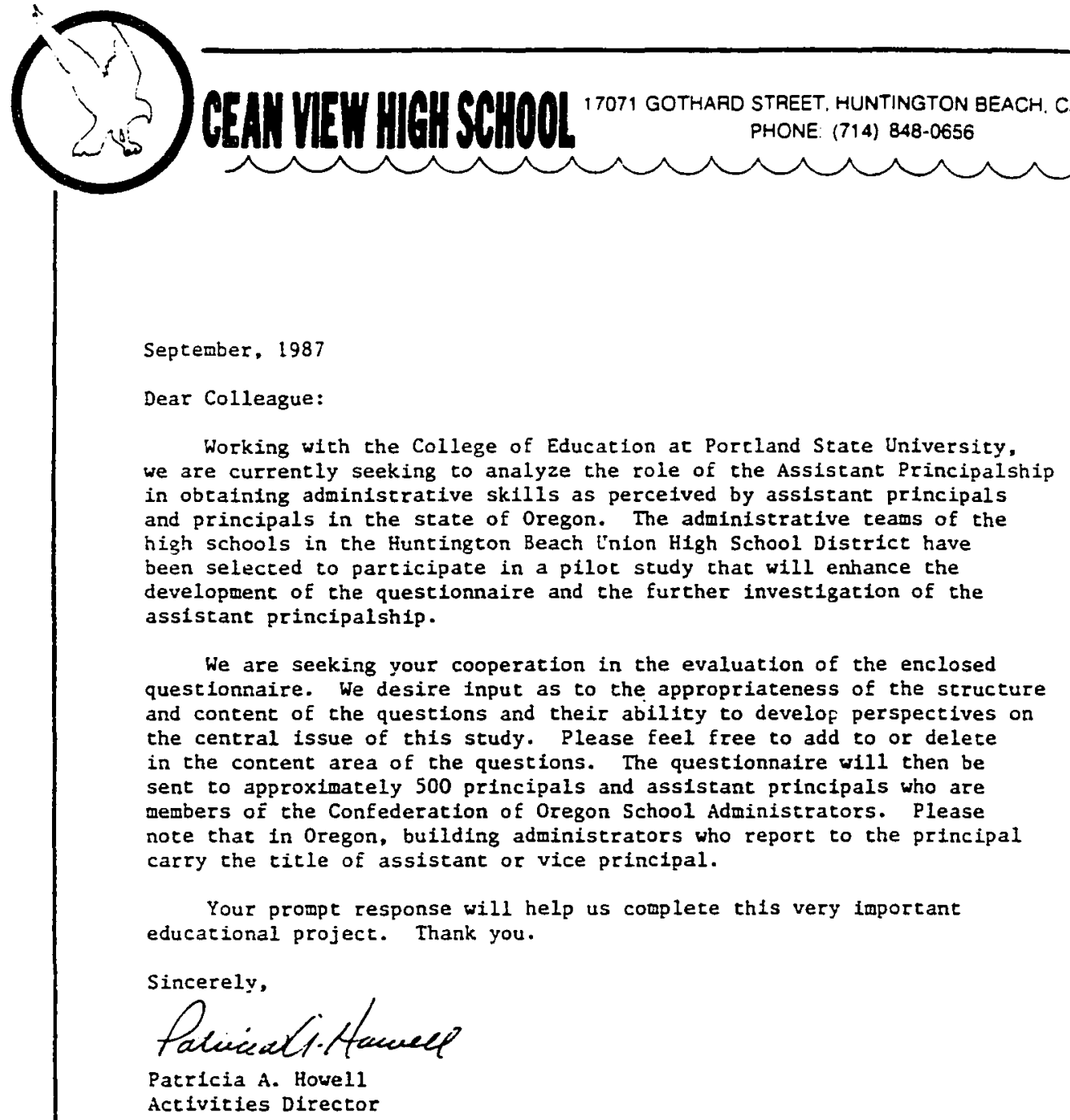


APPENDIX C

PILOT STUDY QUESTIONNAIRE 
AN ANALYSIS OF THE ROLE OF THE ASSISTANT PRINCIPALSHIP

IN! OBTAINING ADMINISTRATIVE SKILLS

\author{
by \\ Patricia A. Howell
}

\begin{abstract}
Submitted in Partial Fulfillment
of the Requirements for

the Doctor of Education Degree

in Educational Leadership
\end{abstract}

School of Education

Portland State University

Portland, Oregon

September, 1987 
QUESTIONNAIRE

An Analysis of the Role of the Assistant Principalship

in Obtaining Administrative Skills

The information desired by this questionnaire will hopefully resolve the following objective:

What effect do the present on-site duties of an assistant principal have in obtaining the necessary skills for professional advancement?

1. To what extent does the present job description of an Assistant Principal at your high school prepare you for the role of a principal in the following areas: Please circle one response for each item.
A. discipline
B. curriculum development
C. budgetary processes
D. comnunity relations
E. teacher supervision/evaluation
F. staff development
G. on-site building maintenance
H. athletic supervision
I. activity supervision
J. other

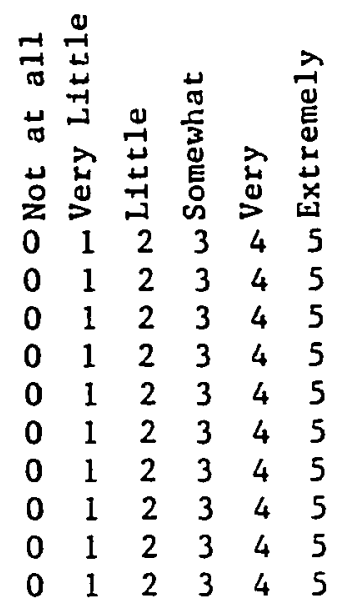

2. To what extent does there tend to be a stereotyping by sex as to the capability to perform assignments in the following roles. Please circle one response for each item.
A. discipline
B. curriculum development
C. budgetary processes
D. community relations
E. teacher supervision/evaluation
F. staff development
G. on-site builidng maintenance
H. athletic supervision
I. activity supervision
J. other

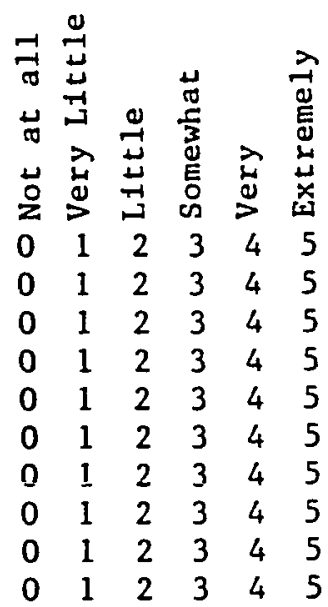


3. To what extent do supervision/evaluation duties prepare the Assistant Principal to evaluate potential new personnel within the scope of district hiring policies? Please circle one response.

4. To what degree does supervision/evaluation prepare the Assistant Principal to handle staff complaints and problems?

Please cirlce one response.

5. What effect does the size of the administrative staff have on the depth in which the Assistant Principal is able to understand the complexity of job assignments given to him/her? Please circle one response.

6. To what extent to you feel there needs to be clarification as to the exact role of the Assistant Principal? Please circle one response.

7. To what degree do you believe being an Assistant Principal in and of 1tself can be a satisfactory professional goal? Please circle one response.
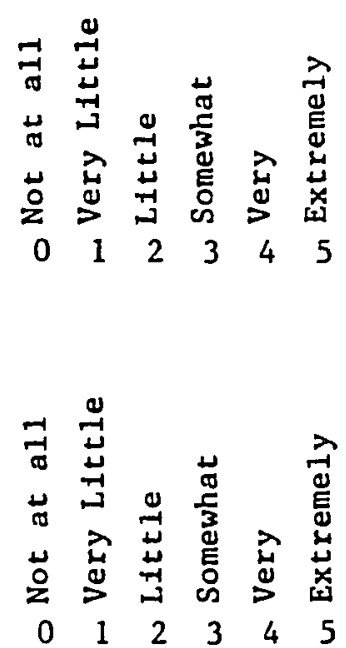
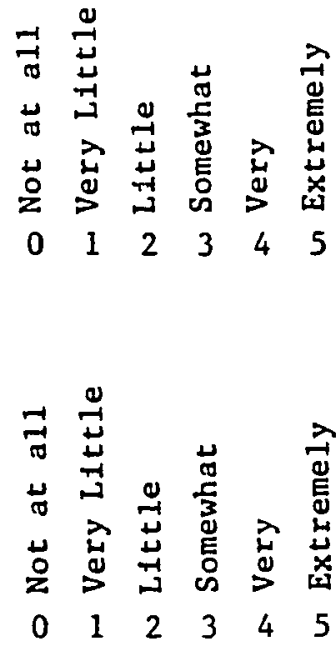


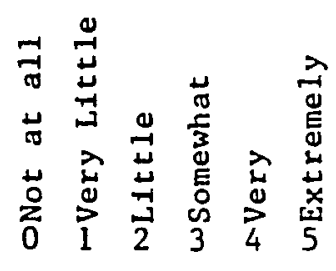

8. To what degree do the number of assignments given each Assistant Principal effect their ability to obtain administrative skills? Please circle one response.

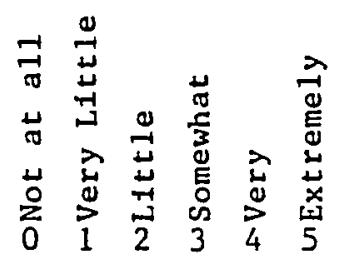

10. To what degree does an Assistant Principal have professional interaction with individuals that he/she would have to interact with as a principal?

Please circle one response.

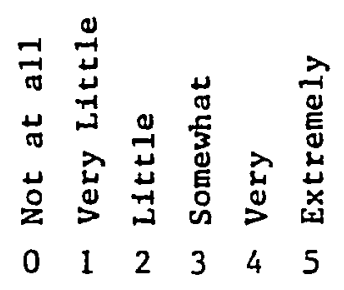

11. Does the length of time as an Assistant Principal have any relationship to the preparation for a principalship? Please circle one response.

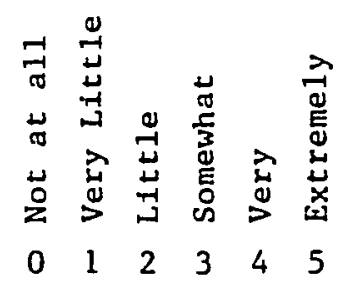

12. To what extent do the Assistant Principal and the Principal communicate with each other as to the structure of the Assistant Principal's role in becoming a principal? Please circle one response.

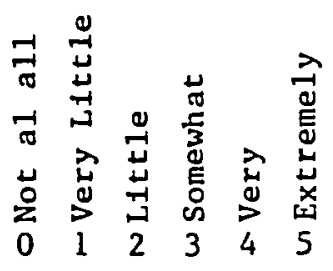


13. To what extent do the experiences of an Assistant Principal provide adequate and appropriate preparation for a principalship? Please circle one response.

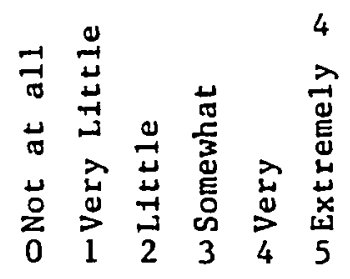

The following demographic questions will be used to ascertain the effects of independent factors on the central issue of the study.

A. Male _ Female

B. Assistant Principal __ Principal

C. Number of years of experience in present position:

$0-3+\quad 4-7+$ over 7

D. Number of years of experience as an Assistant Principal before being promoted to Principal:

$0-3$

4-7

over 7

E. Professional Background:

Initially prepared for administration

Moved into administration from teaching

F. Number of Assistant Principals in building:

$0-2$

3-5

over 5

G. Number of major job assignments in your position:

$0-2$

3-5

$5-7$

over 7 
APPENDIX D

ALPHABETICAL LIST OF COSA MEMBERS SURVEYED 


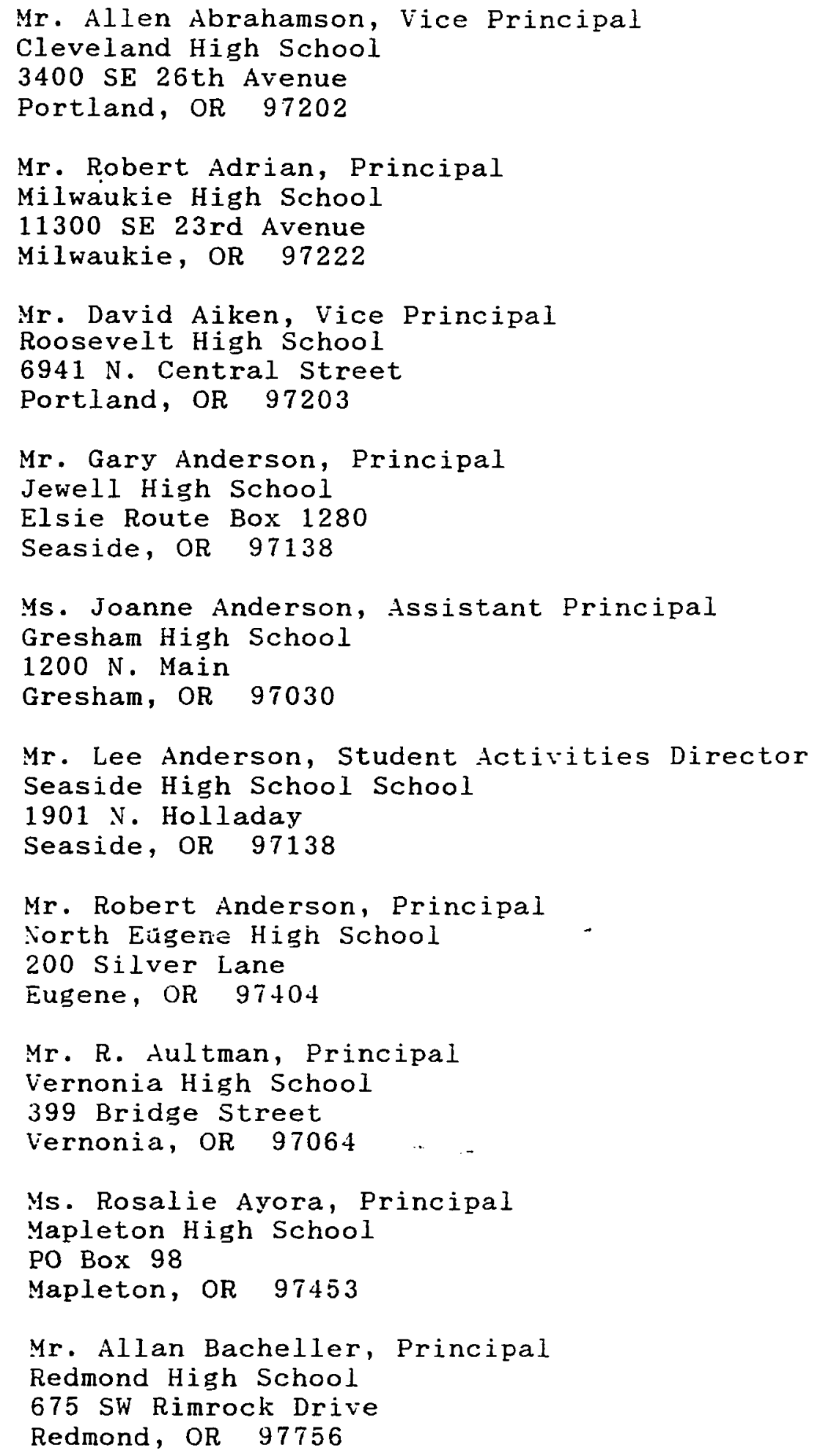




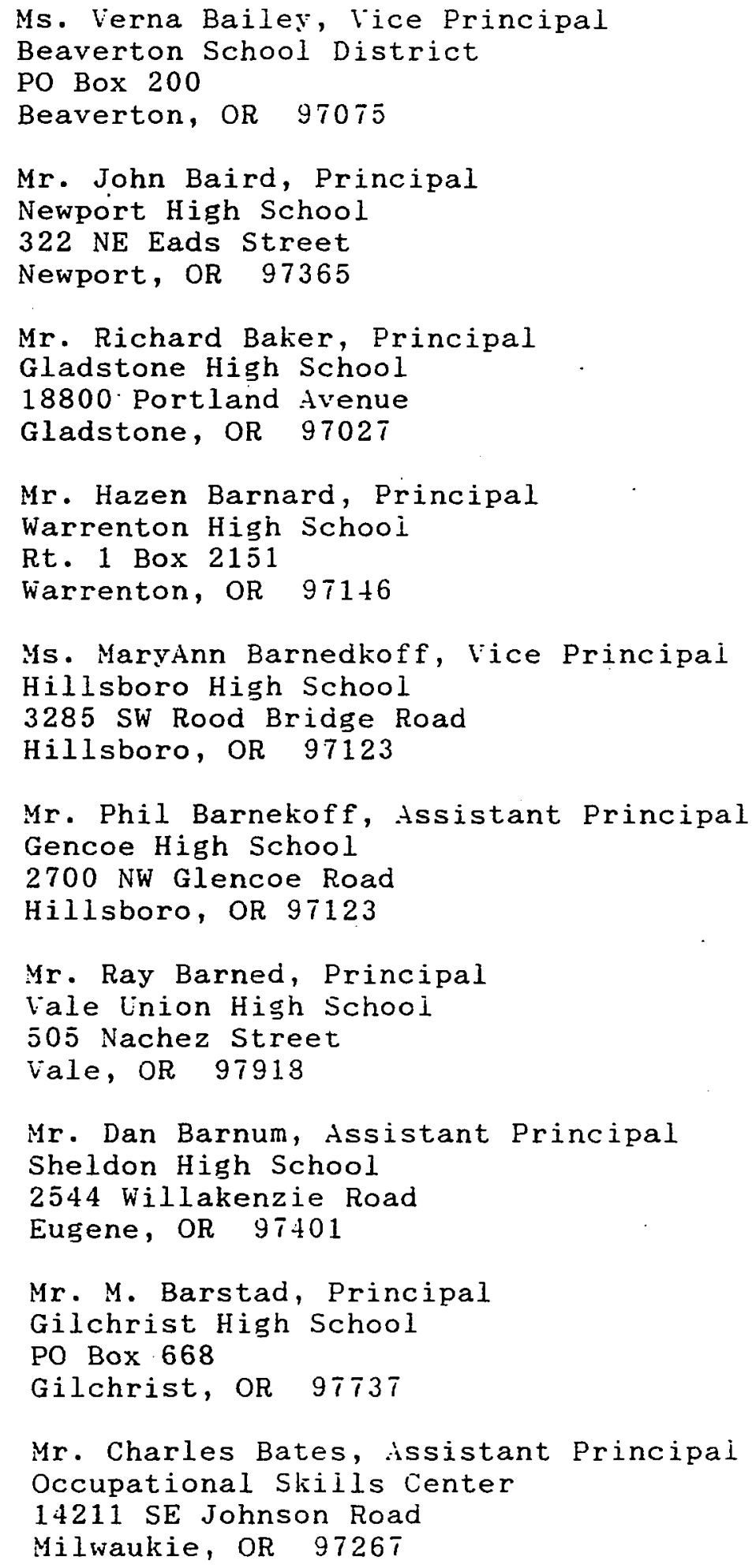




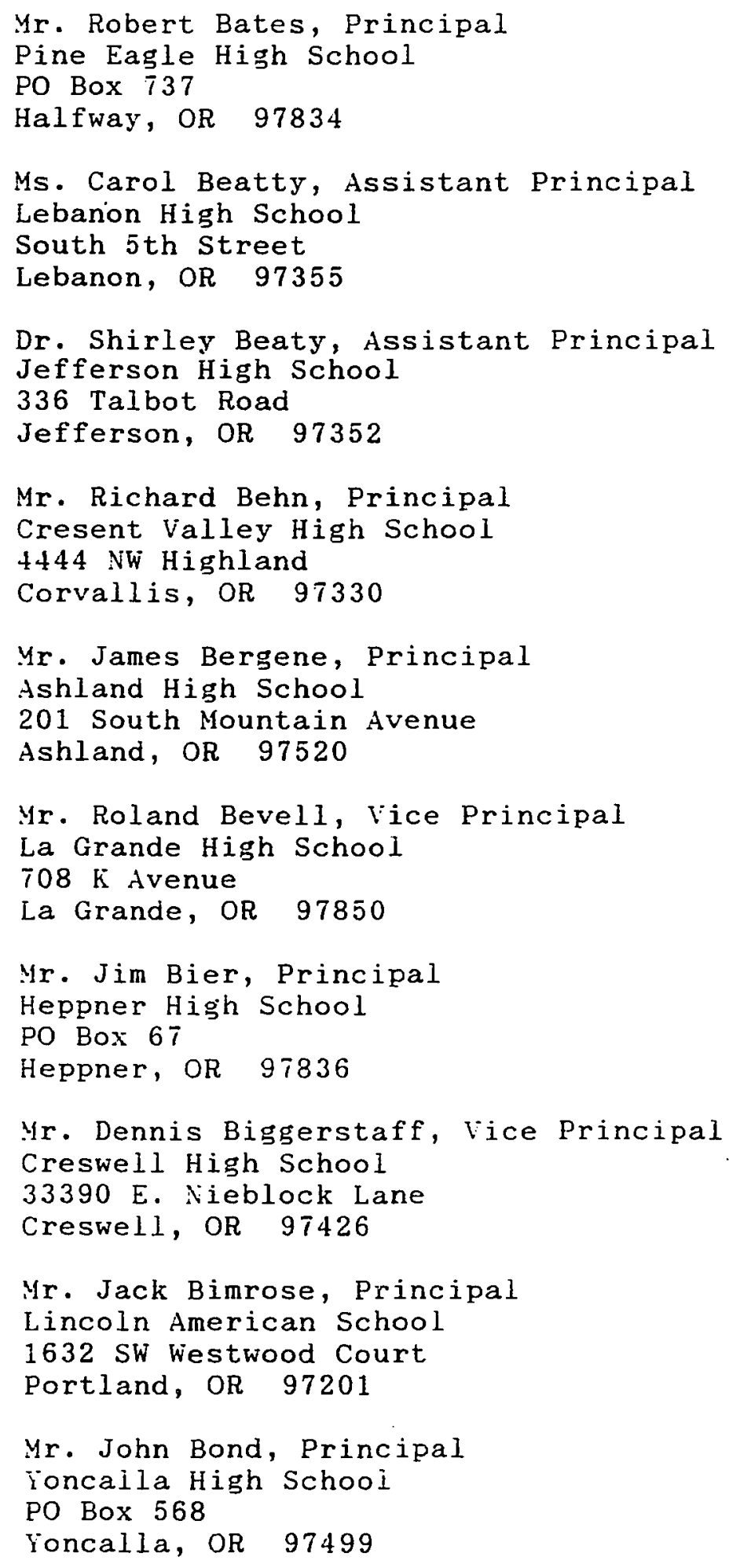


Mr. David Booher, Assistant Principal

Lakeridge High School

1235 Sw Overlook Drive

Lake Oswego, OR 97034

Ms. Dolores Bowman, Vice Principal

Jefferson High School

5210 N. Kerby

Portland, OR 97217

Mr. Joseph Bowman, Principal

Portland Evening High School

51515 th Avenue

Portland, OR 97232

M. Chris Boyle, Assistant Principal

waldport High School

PO Box 270

waldport, on 97394

Mr. Marvin Brenneman, Principal

Pleasant Hill High School

36386 Highway 58

Pleasant Hill, OR 97401

Mr. Beryl Brodersen, Assistant Principal

North Salem High School

76514 th NE

Salem, OR 97301

Mr. Dennis Brooks, Principal

Iiillamina High Schooi

266 washington Street

willamina, OR 97396

Mr. Gerry Brown, Vice Principal

Canby Union High School

i21 SW 4 th Street

Canby, OR 97013

Mr. Kenneth Brown, Assistant Principal

Dallas High School

901 SE Ash Street

Dallas, OR 97338

Mr. Ron Brown, Principal

Imbler High School

Imbler, OR 97841 
Mr. Ronald Brown, Assistant Principal Sprague High School

2373 Kuebler Road South

Salem, OR 97302

Mr. Donald Bryant, Dean of Students

Grants Pass High School

522 NE Olive Street

Grants Pass, OR 97527

Mr. Grant Budge, Assistant Principal

Hidden Valley High School

651 Murphy Creek Road

Grants Pass, OR 97527

Sister Mary Burke, Principal

St. Mary's Academy

1615 SW Fifth Avenue

Portland, OR 97201

Mr. Jack Burri, Assistant Principal

Newport High School

311 NE Eads Street

Newport, OR 97365

Mr. Robert Buss, Adm. Assistant

Thurston High School

$333 \mathrm{~N} 58 \mathrm{th}$ Street

Springfield, OR $974 i \pi$

Ms. Marilyn Bryne, Assistant Principal

North Eugene High School

200 Silver Lane

Eugene, OR 97404

Mr. Guido Caldarazzo, Principal

Mckay High School

2440 Lancaster Drive $\mathrm{NE}$

Salem, OR 97305

Mr. Jerry Campbeil, Assistant Principal

Estacada High School

500 NE Main street

Estacada, OR 97023

Mr. Rene Cardiff, Dean of Students

Roseburg High School

$5+7$ west Chapman Avenue

Roseburg, OR 97470 


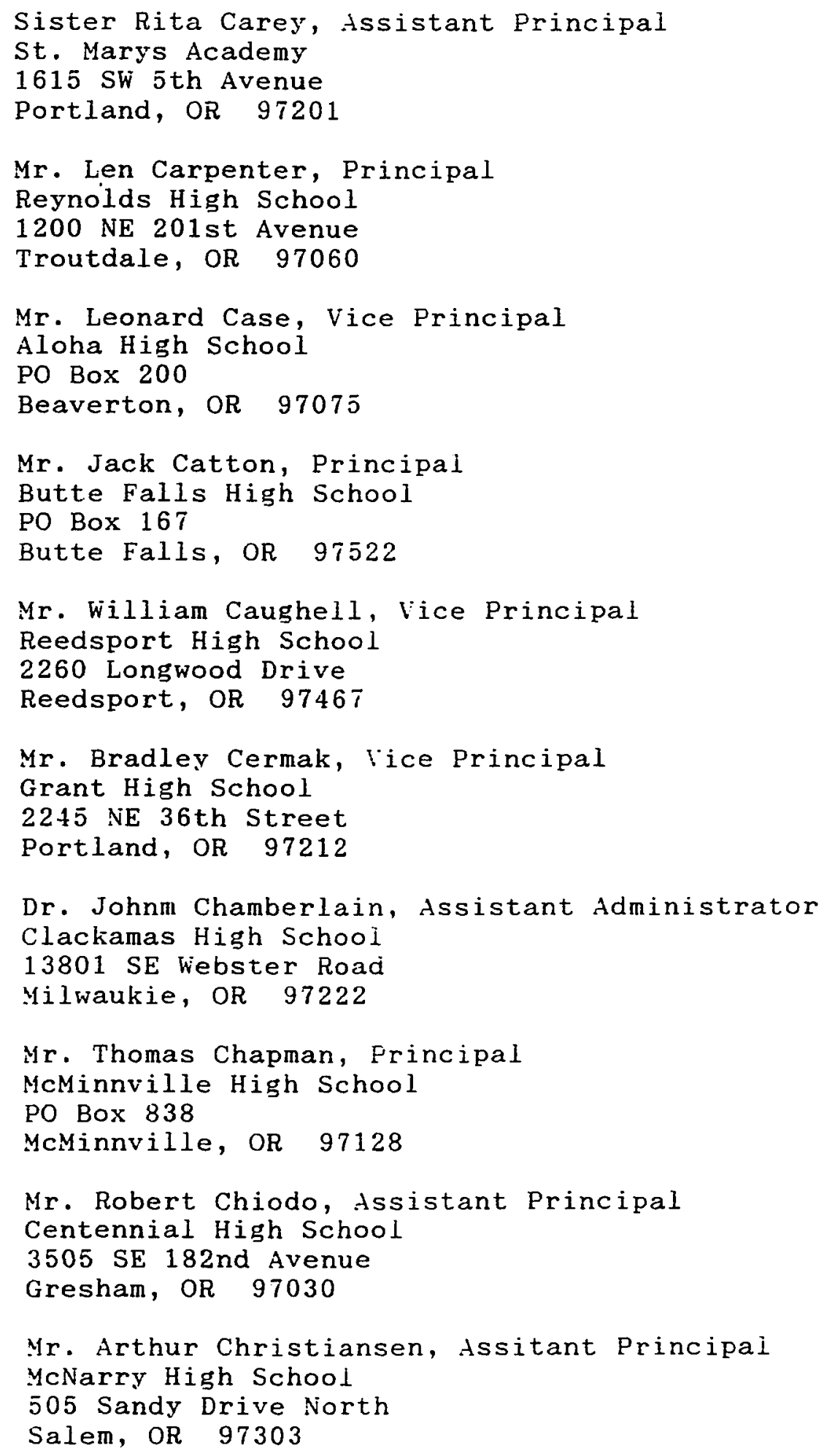




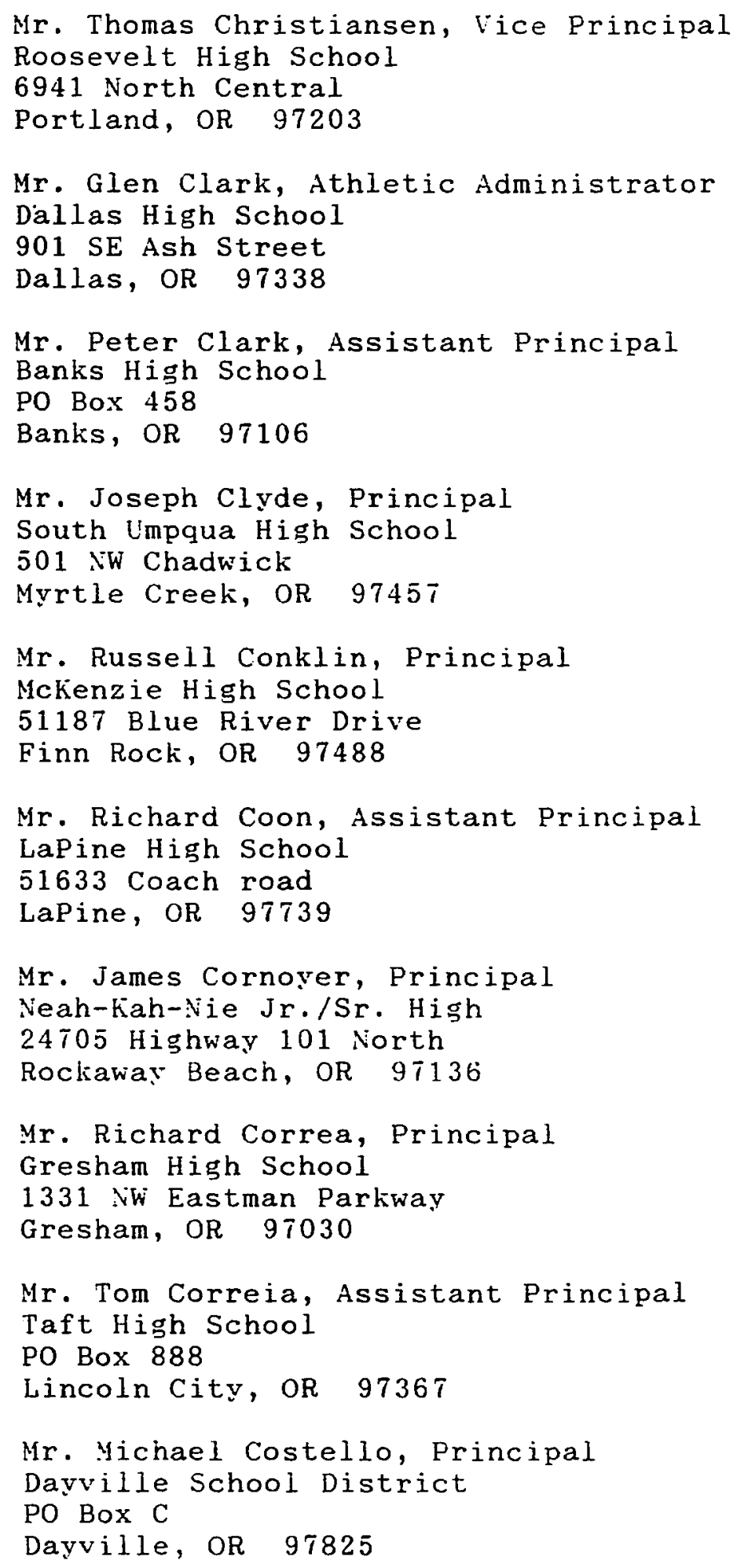


Ms. Laura Couture, Principal

Rainier High School

PO Box 498

Rainier, OR 97048

Mr. John Cover, Vice Principal

Lincoln $\mathrm{High}$ School

1600 SW Salmon Street

Portland, OR 97105

Mr. Patrick Cowan, Principal

Elgin High School

PO Box 68

Elgin, OR $\cdot 97827$

Ms. Joan Crosby, Vice Principal

Grant High School

$2245 \mathrm{NE} 36 \mathrm{th}$ Avenue

Portland, OR 97212

Mrs. Nancy Cross, Vice Principal

Tigard High School

9000 SW Durham Road

Tigard, OR 97223

Ys. Beverly Crouter, tssistant Principal

Santiam High School

PO Box 199

Mill City, oR 97360

Mr. Dennis Crow, Assistant Principal

Sandy High School

17100 Bluff Road

Sandy, OR 97055

Mr. Paul Curtis, Principai

Pendleton High School

$1800 \mathrm{NW}$ Carden

Pendleton, OR 97801

Mr. Sam Daterman, Assistant Principal

Riverside High School

PO Box 140

Boardman, OR 97818

Mr. Edwin Davidson, Principal

Corw High School

25863 Crow Road

Eugene, OR 97402 


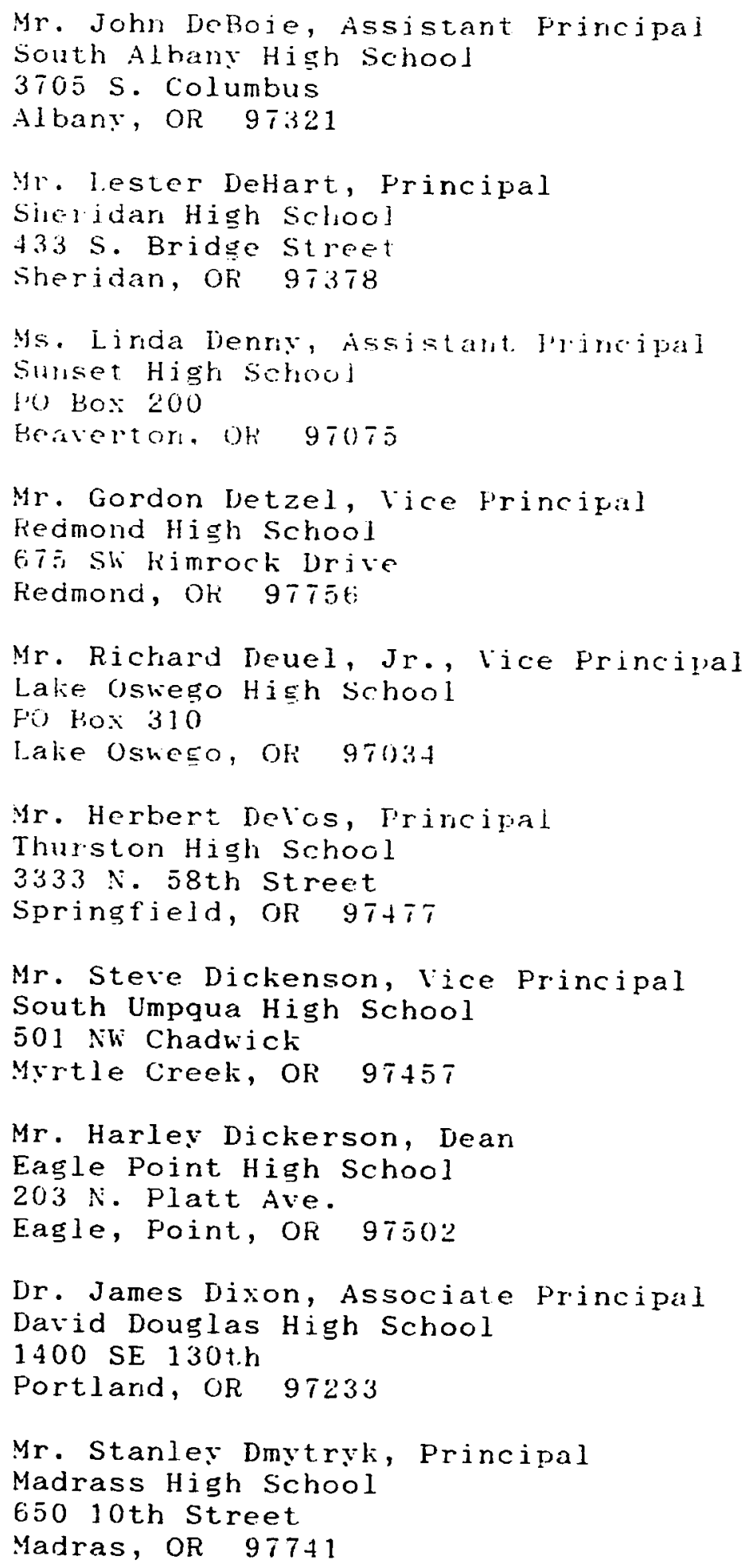




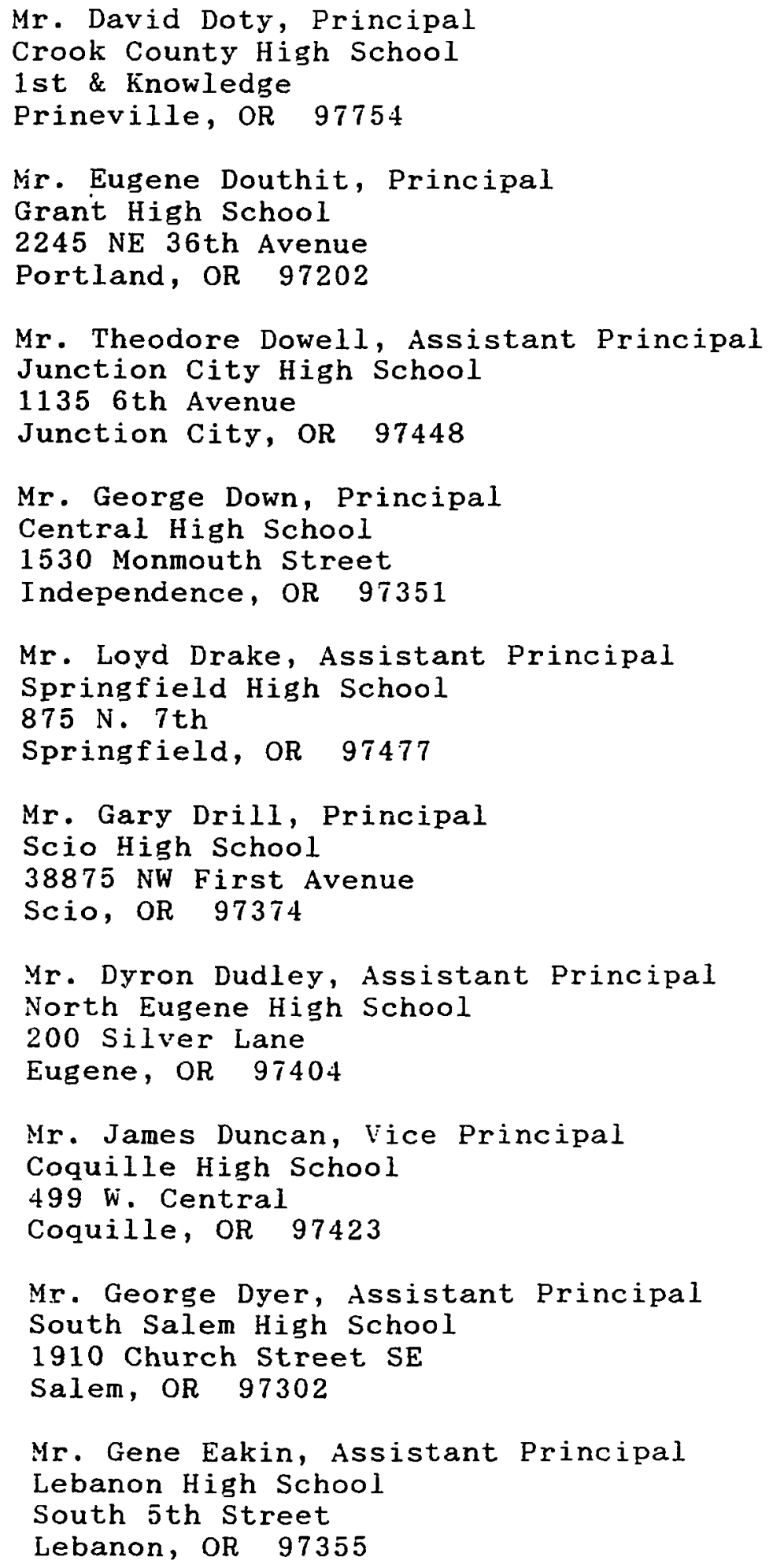




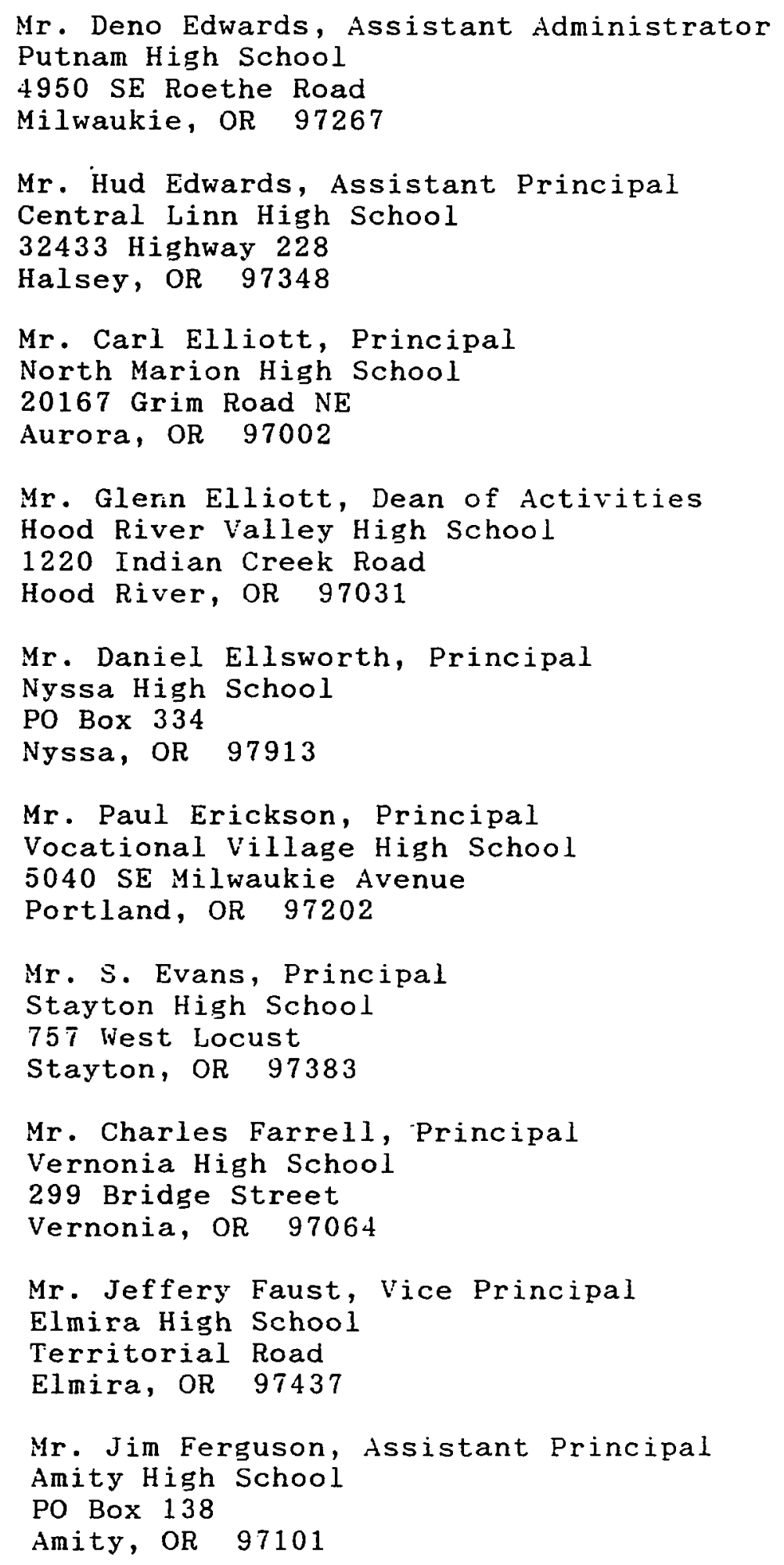




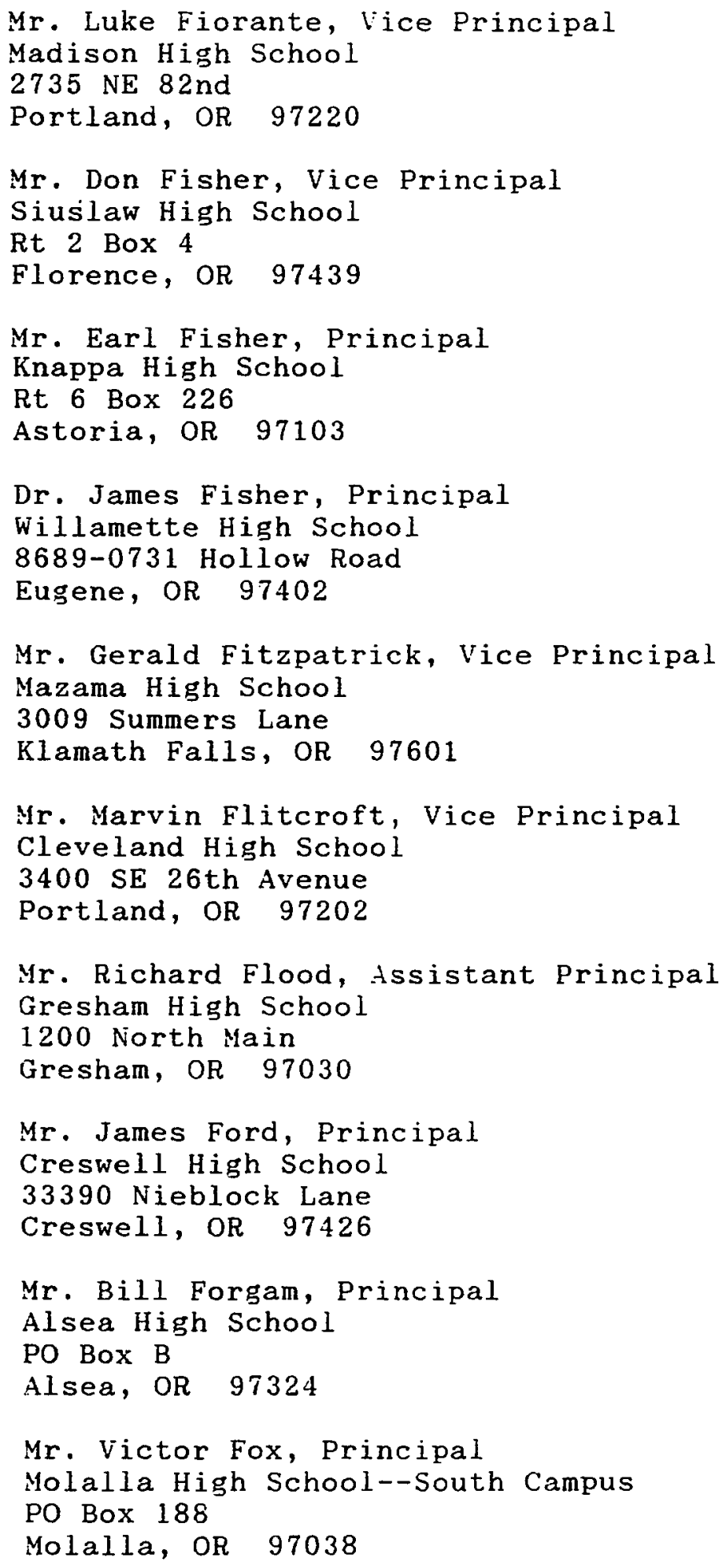




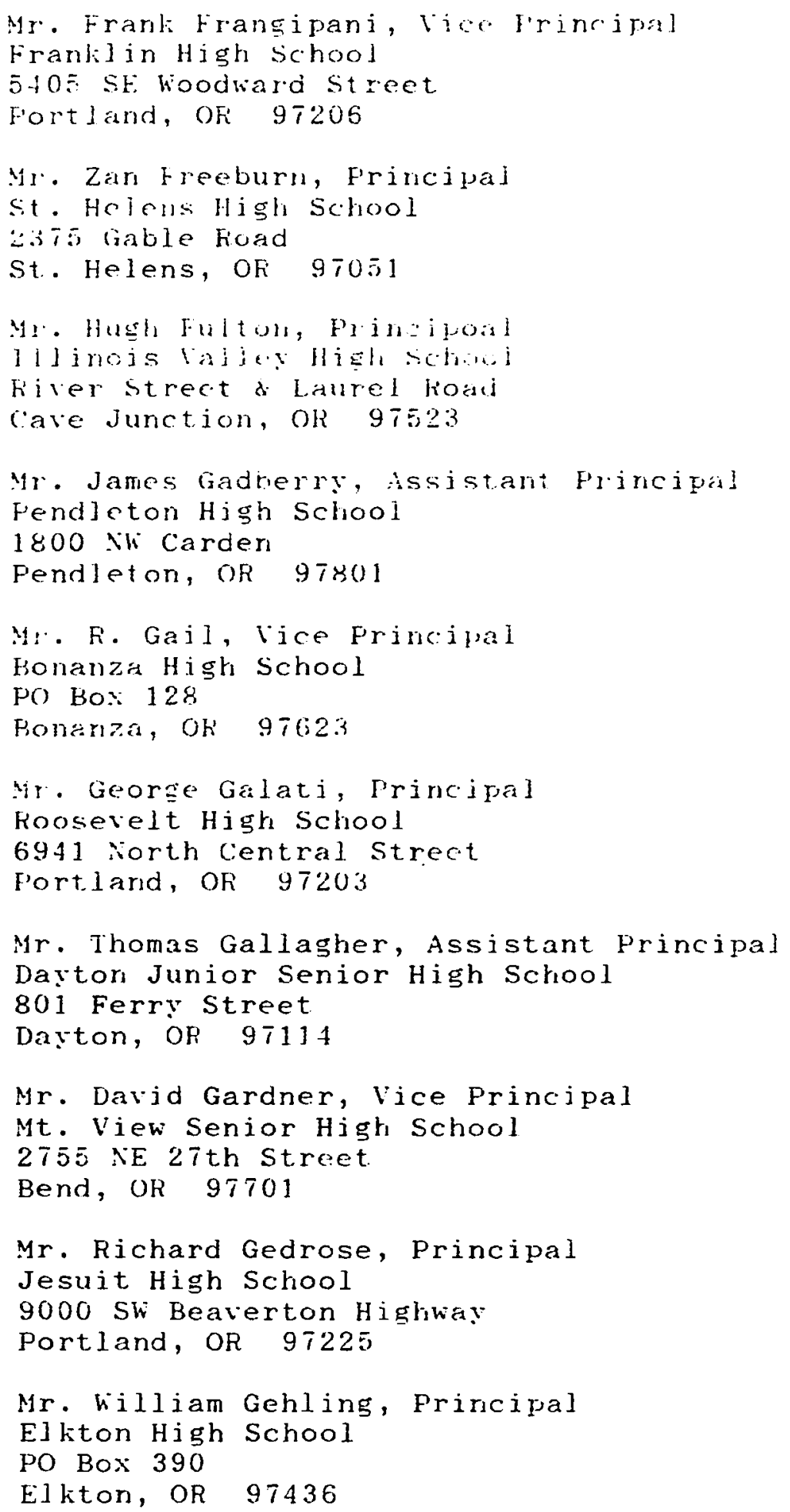


Mr. Charles Geis, Principal

St. Paul School District

$600 \mathrm{NW}$ Main Street

St. Paul, OR 97137

Mr. William Gieber, Principal

Reedsport High School

2260 Longwood Drive

Reedsport, OR 97467

Mr. Keith Gillis, Principal

Central Linn High School

32433 Highway 228

Halsey, OR 97348

Mrs. Claudia Girod, Vice Principal

David Douglas High School

$1500 \mathrm{SE} 130$ th Avenue

Portland, OR 97233

Ms. Beverly Gladder, Principal

Aloha High School

PO Box 200

Beaverton, OR 97075

Ms. Shirley Glick, Principal

Portland School District

PO Box 3107

Portland, OR 97208

Mrs. Harriet Goglin, Vice Principal

Canby High School

i21 SW 4 th

Canby, OR 97013

Mr. Henry Golden, Principal

Corvallis High School

836 NW 11 th Street

Corvallis, OR 97330

Mr. J. Goodrum, Principal

Rogue River High School

1898 E. Eveans Creek Road

Rogue River, OR $9753 i$

Ir. Christopher Gorchels, Assistant Principal

Parkrose High School

$11717 \mathrm{NE}$ Shaver

Portland, OR 97220 


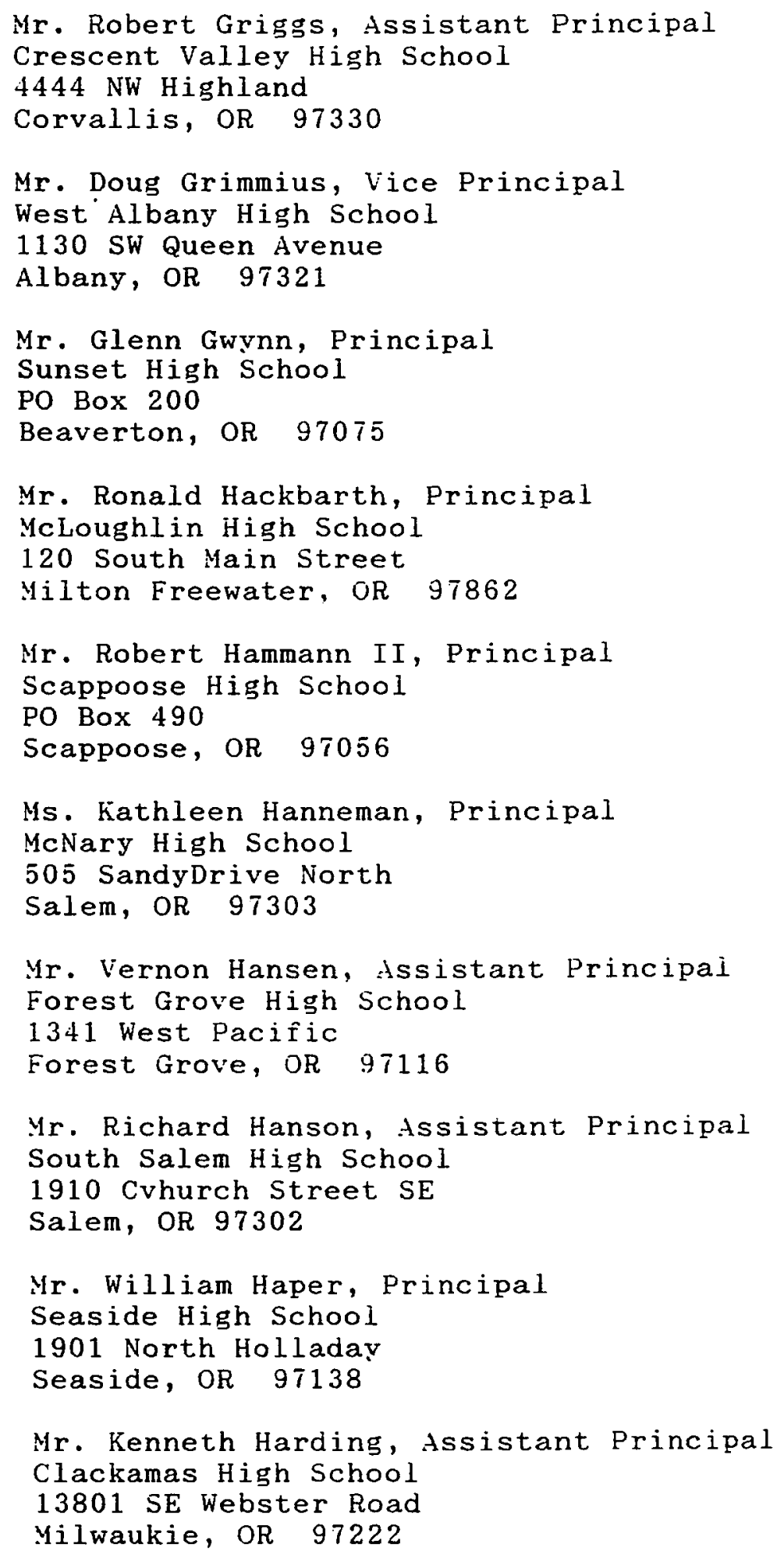




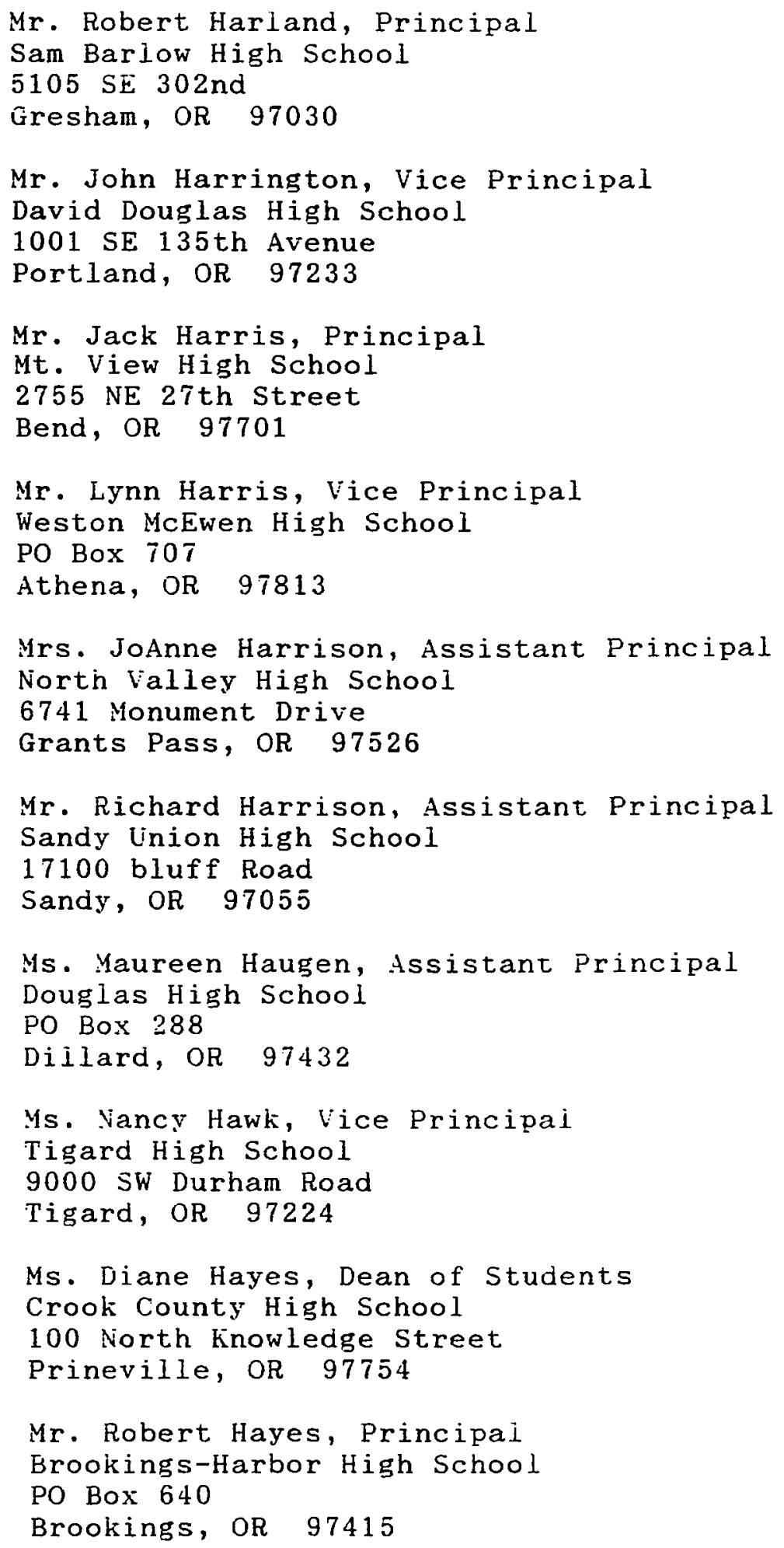


Ms. Audrey Haynes, Vice Principal

Ernaklin High School

5405 SE Woodward Street

Portland, OR 97206

Mr. Harvey Hazen, Principal

Hood River Valley High School

1220 Indian Creek Road

Hood River, OR 97031

Mr. Lawrence Headden, Vice Principal

Klamath County School District

334 Main Street

Klamath Falls, OR 97601

Mr. Donald Hedrick, Principal

Tillamook High School

260512 th Street

Tillamook, OR 97141

Mr. Eugene Heinle, Administrative Assistant

Springfield Senior High School

875 North 7 th Street

Springfield, oR 97477

Mr. Hugo Hendrickson, Principal

wynne Watts School

$930 \mathrm{NE} 162 \mathrm{nd}$

Portland, OR 97230

Mr. Douglas Henry, Vice Principal

Crook County High School

1 st and knowledge Streets

Prineville, oR 97754

Mr. Wayne Hill, Assistant Principal

South Eugene High School

400 E. 19 th

Eugene, OR 97401

Mr. Rick Hintz, Vice Principal

Hillsboro High School

3285 SW Rood Bridge Road

Hillsboro, OR 97123

Mr. Fred Holevas, Assistant Principal

Sam Barlow High School

$5105 \mathrm{SE} 302 \mathrm{nd}$

Gresham, OR 97030 


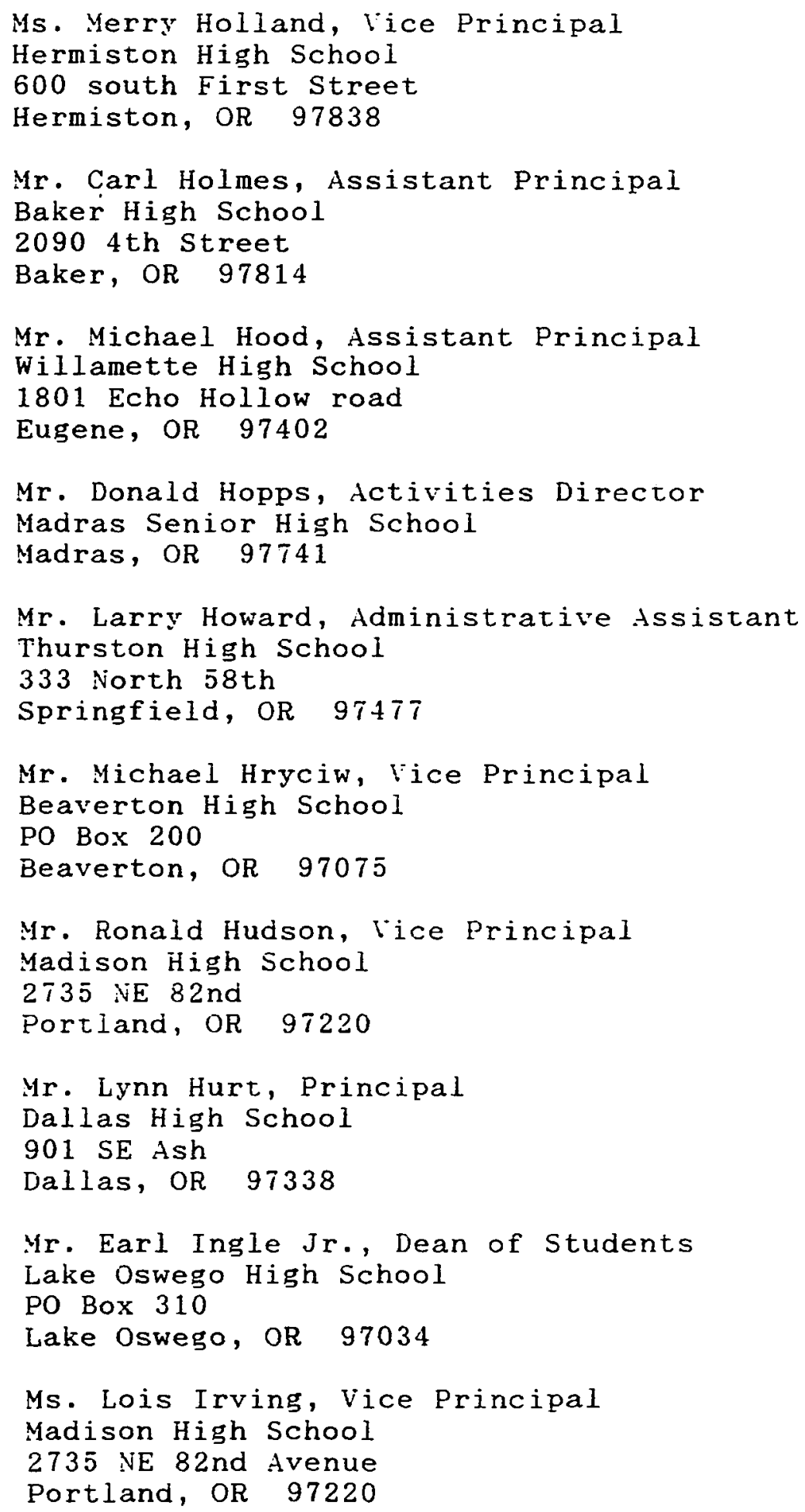




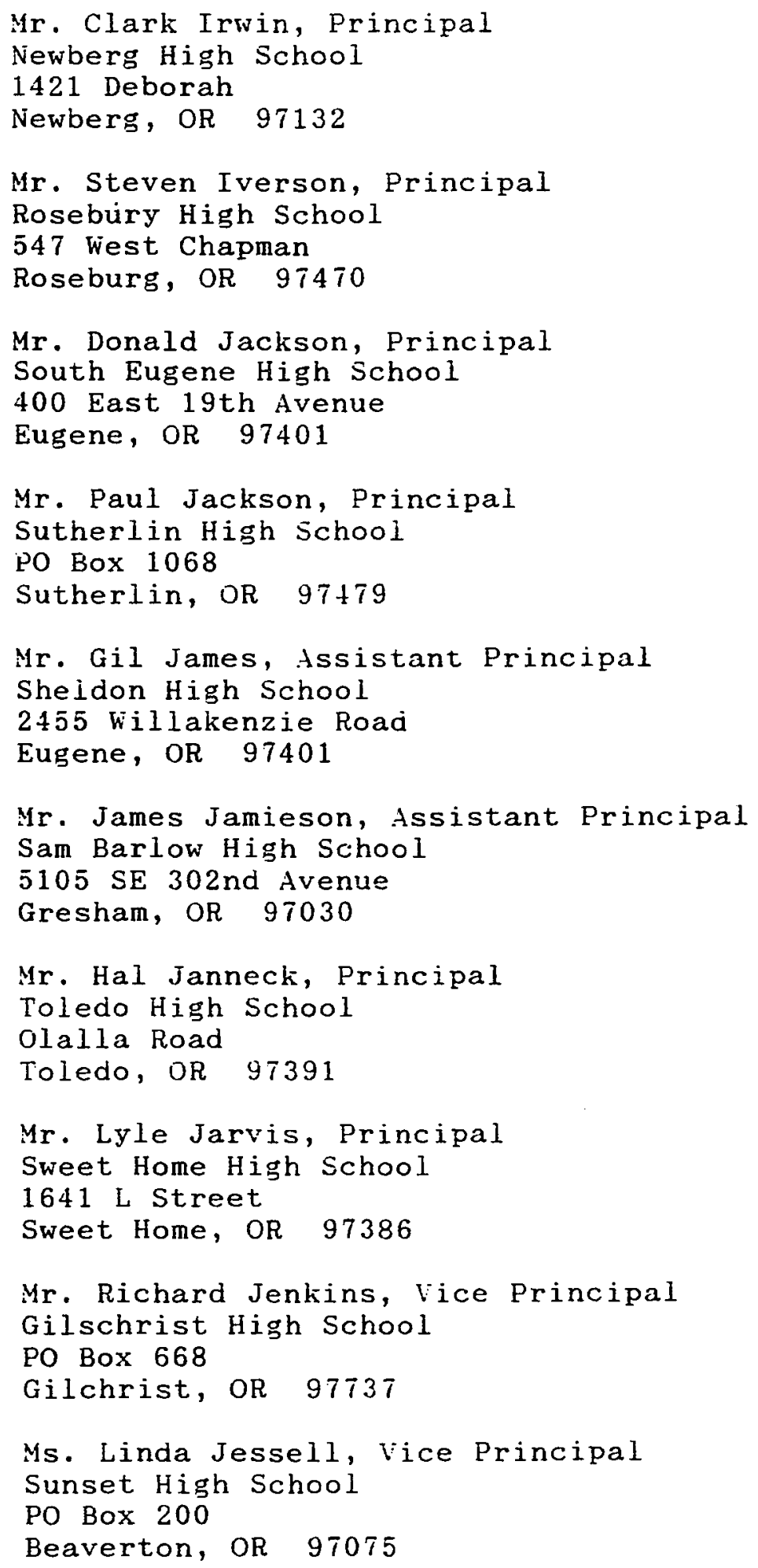


Mr. Edward John, Assistant Principal

Mckay High School

2440 Lancaster Drive $\mathrm{NE}$

Salem, OR 97305

Mr. Daniel Johnson, Principal

Southisalem High School

1910 Church Street SE

Salem, OR 97302

Mr. Larry Johnson, Vice Principal

Sweet Home High School

1641 Long Street

Sweet Home, OR 97386

Ms. Monita Johnson, Vice Principal

North Bend High School

14 th \& Pacific

North Bend, oR 97459

Mr. Stephen Johnson, Principal

Dayton High School

801 Ferry Street

Dayton, OR 97114

Ms. Stephanie Johnson, Assistant Principal

South Medord High School

815 South Oakdale

Medford, OR 97501

Ms. Velma Johnson, Vice Principal

Marshall High School

3905 SE 91 st ivenue

Portland, OR 97266

Ms. Wanda Johnson, Assistant Principai

South Eugene High School

400 East 19 th

Eugene, OR 97405

Mr. Richard Johnstone, Vice Principai

Brookings Harbor High School

PO Box 640

Brookings, OR 97415

Mr. David Jones, Principal

wahtonka High School

3601 west 10 th

The Dalles, OR 97058 


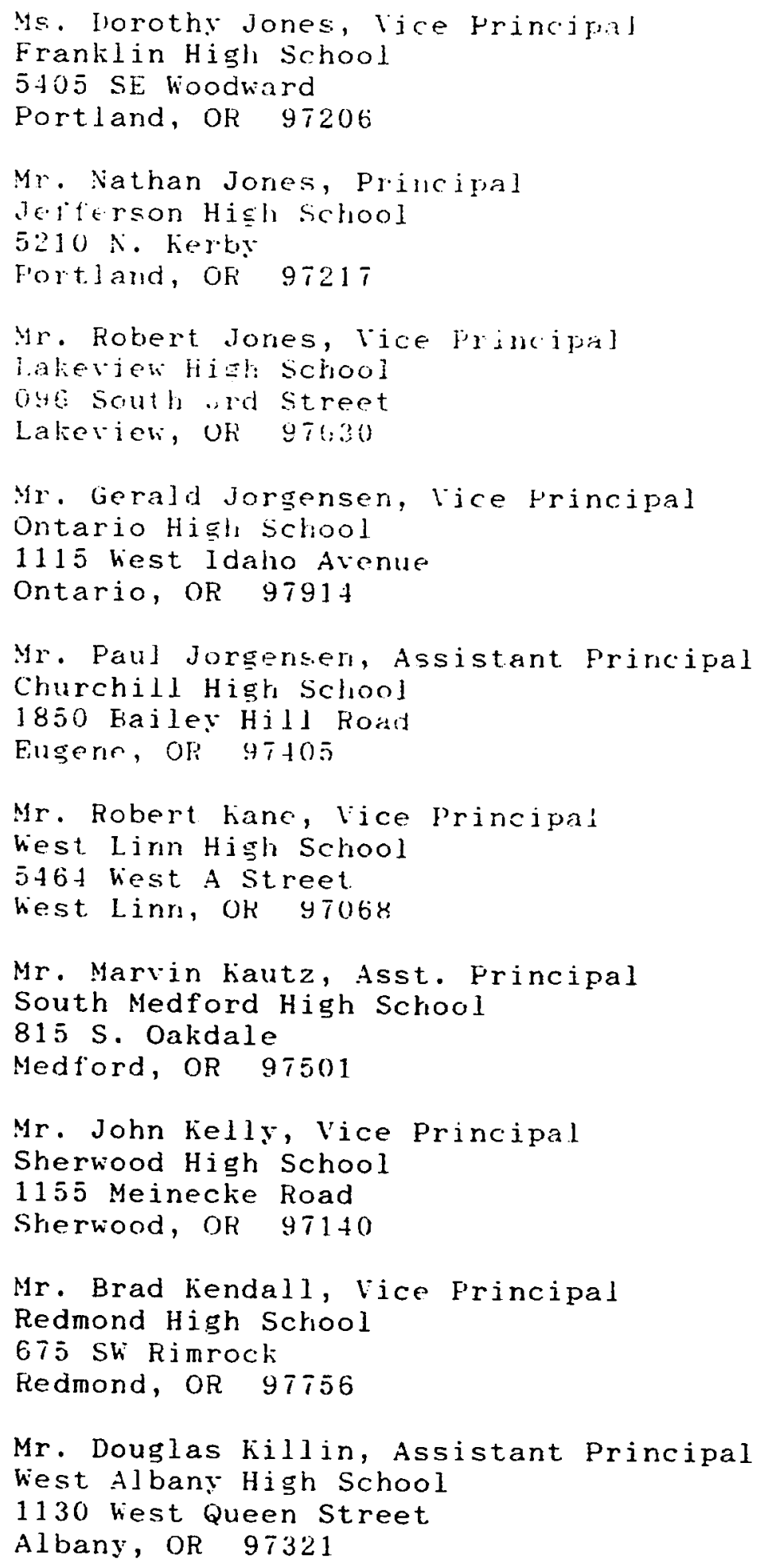




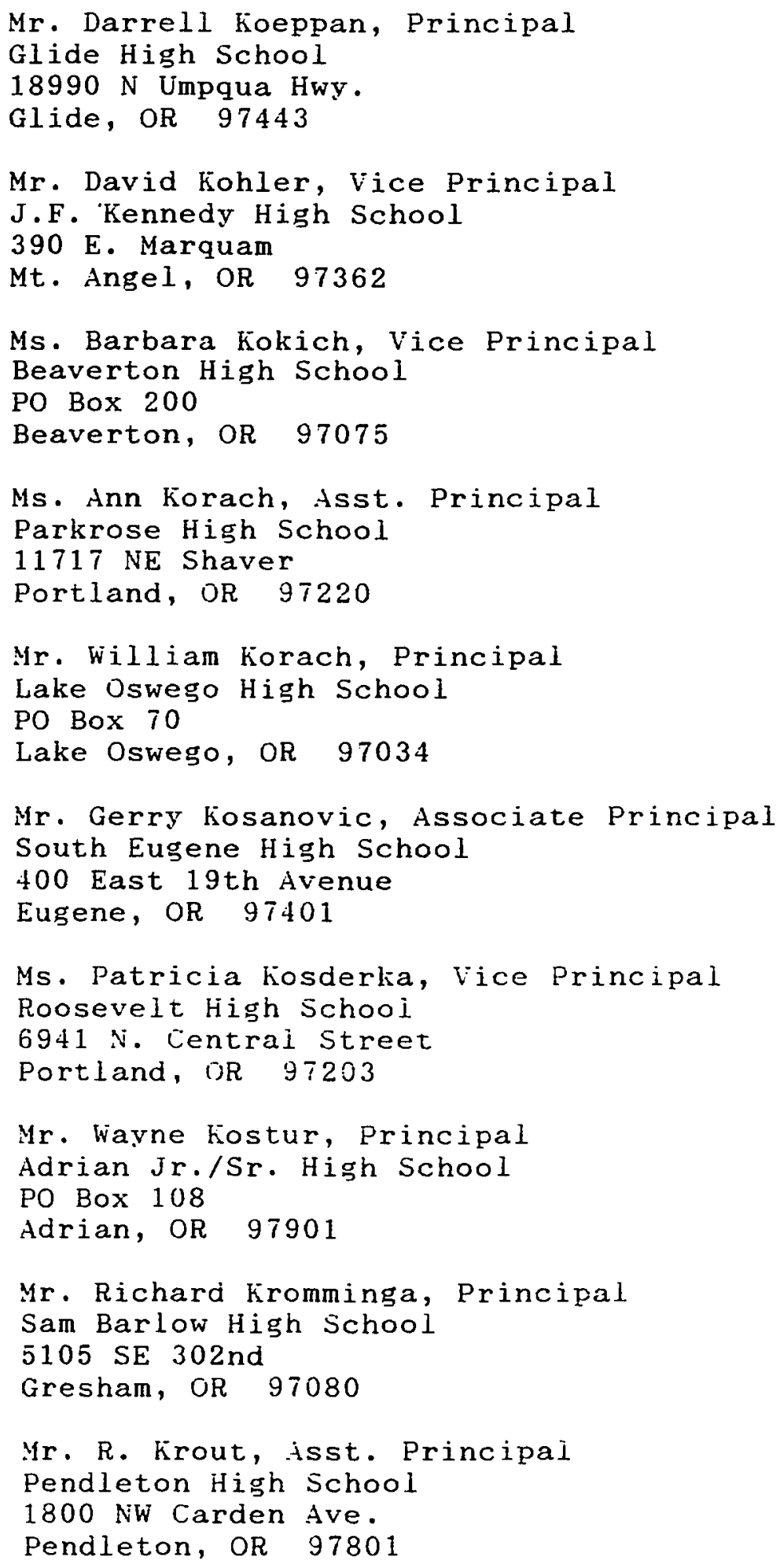




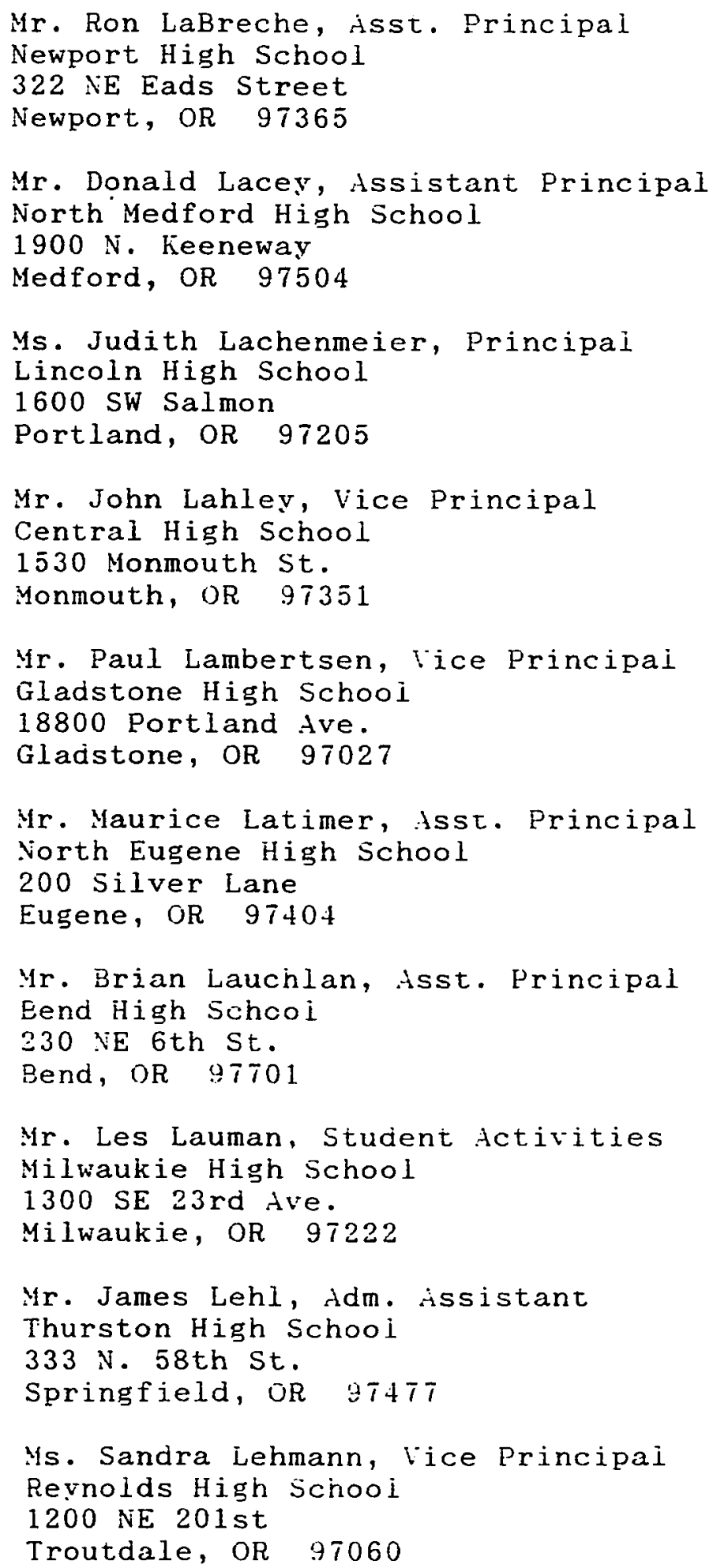


Mr. Richard Lennert, Principal

Pilot Rock High School

PO Box 88

Pilot Rock, OR 97868

Ms. Darlene Leighty, Vice Principal

woodburn High School

$1785 \mathrm{~N}$. Front St.

Woodburn, OR 97071

Mr. Rodney Leland, issistant Principal

Gervais Union High School

P.O. Box 195

Gervais, OR 97026

Mr. John Lewis, Principal

Hillsboro High School

3285 SW Road Bridge Road

Hillsboro, OR 97123

Ms. Maureen Liles, Vice Principal

west Albany High School

1130 SW Queen

Albany, OR 97321

Dr. Thomas Lindersmith, Principal

Lakeridge High Schooi

PO Box 739

Lake Oswego, OR 97034

Mr. Paul Lindquist, Principal

North Valley High School

$6 i 41$ Monument Drive

Grants Pass, OR 97526

Mr. Carl Lino, Principal

Grnat Linion High School

PO Box 129

John Day: OR 97845

Ys. Jeanne Lough, isst. Principal

Henley High School

8245 Hwy 39

Klamath Falls, OR 97603

Mr. Donald Lowrance, Principal

Clatskanie High School

P.O. Box 68

Clatskanie, OR 97016 


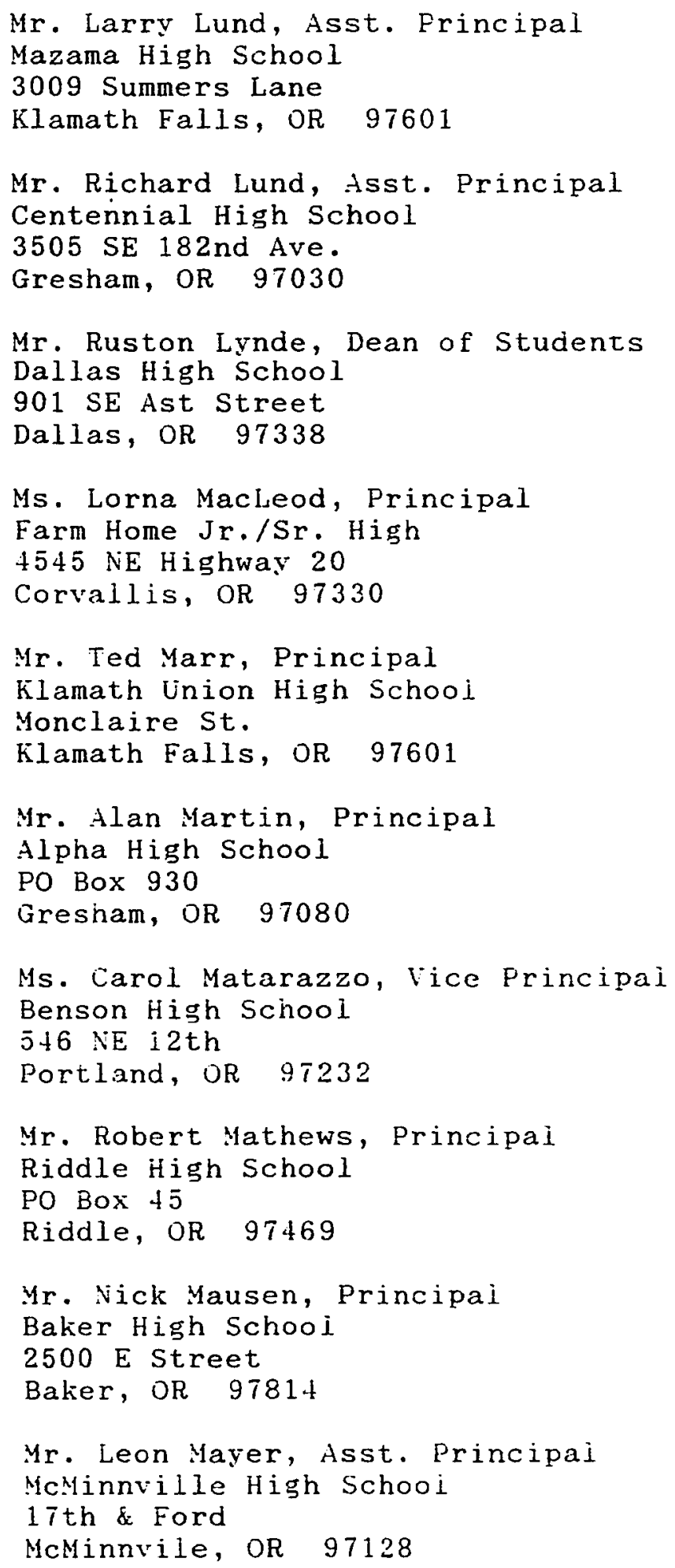




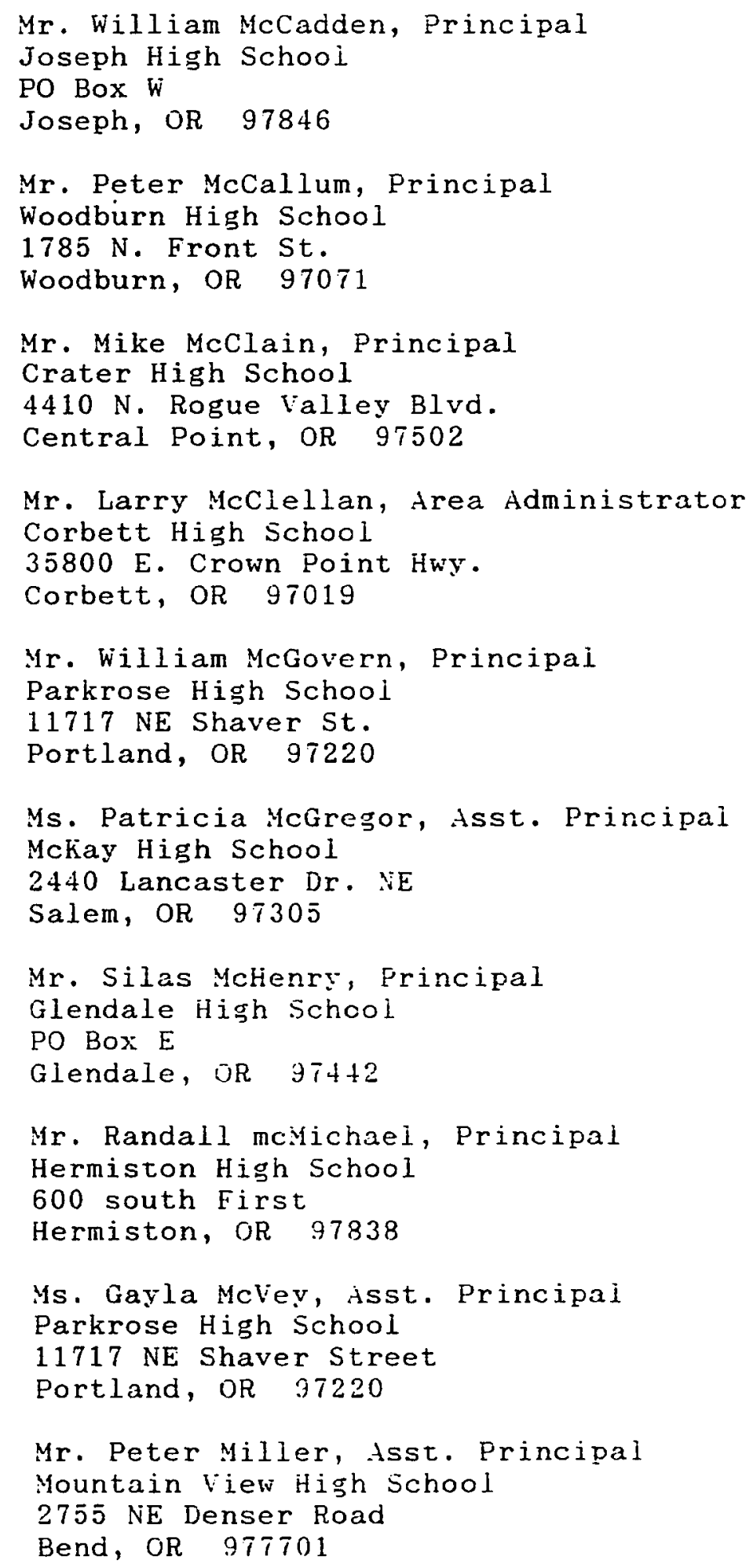




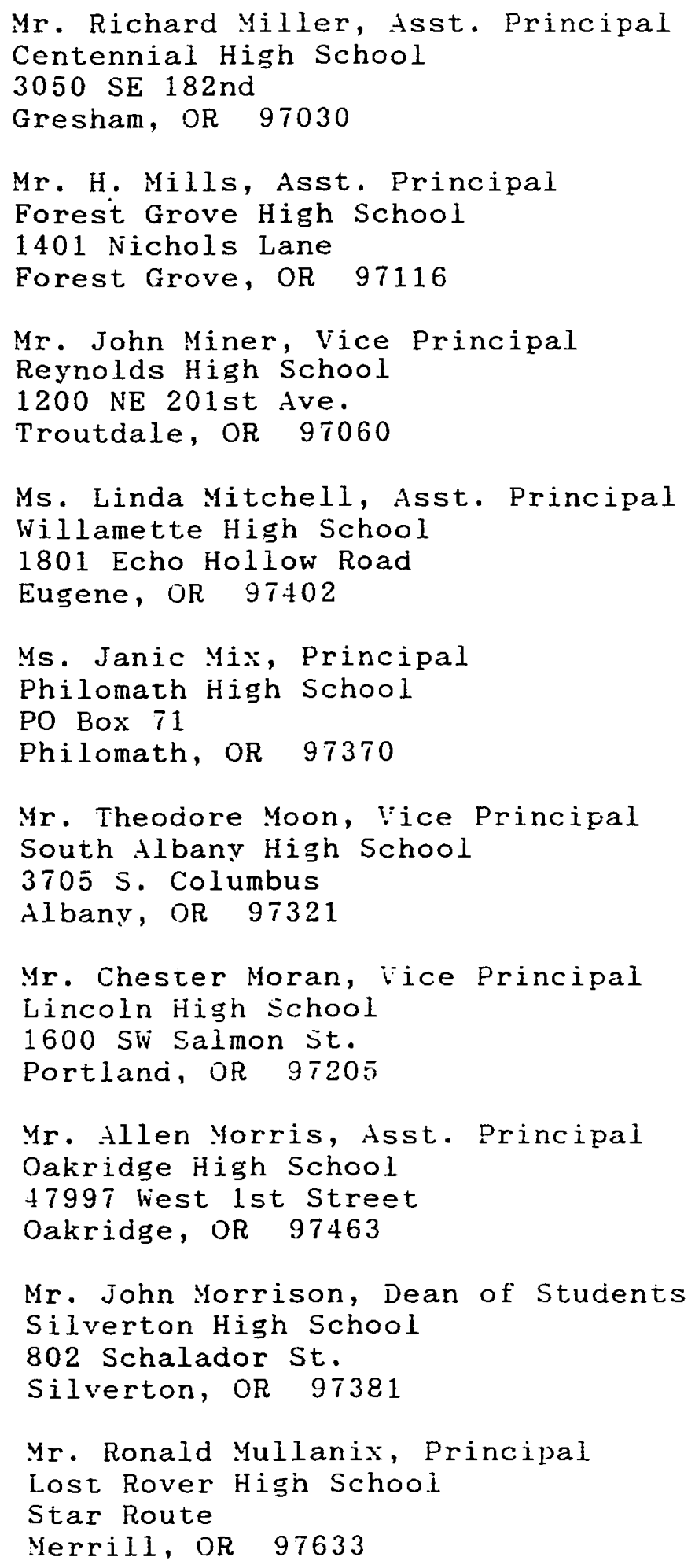




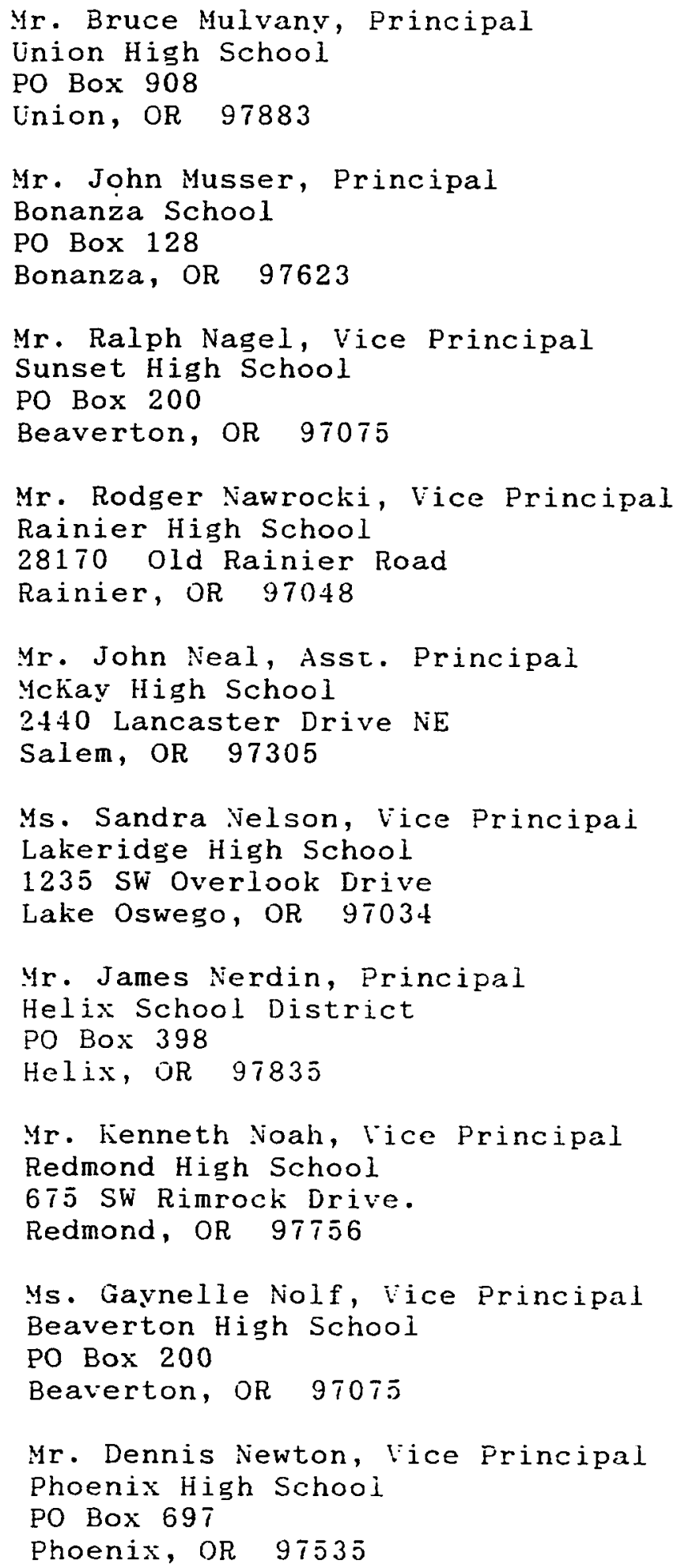




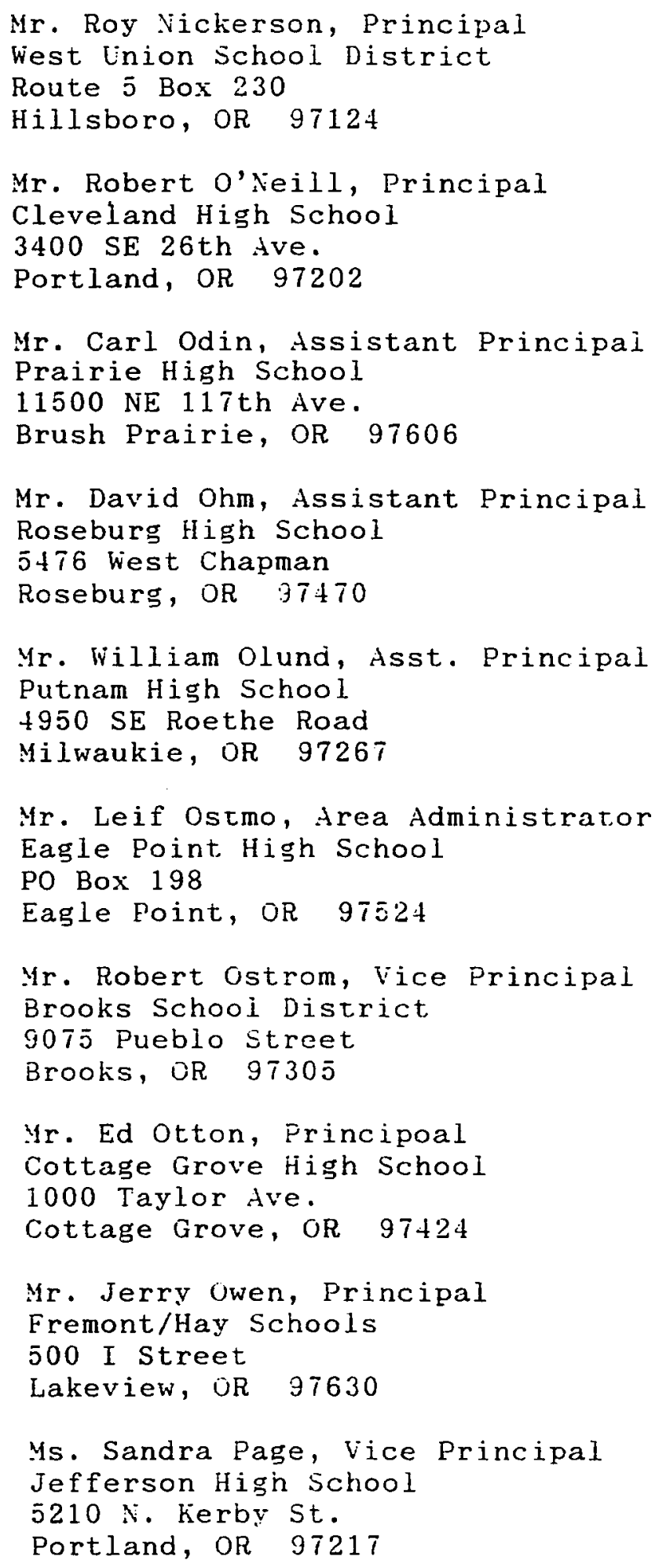




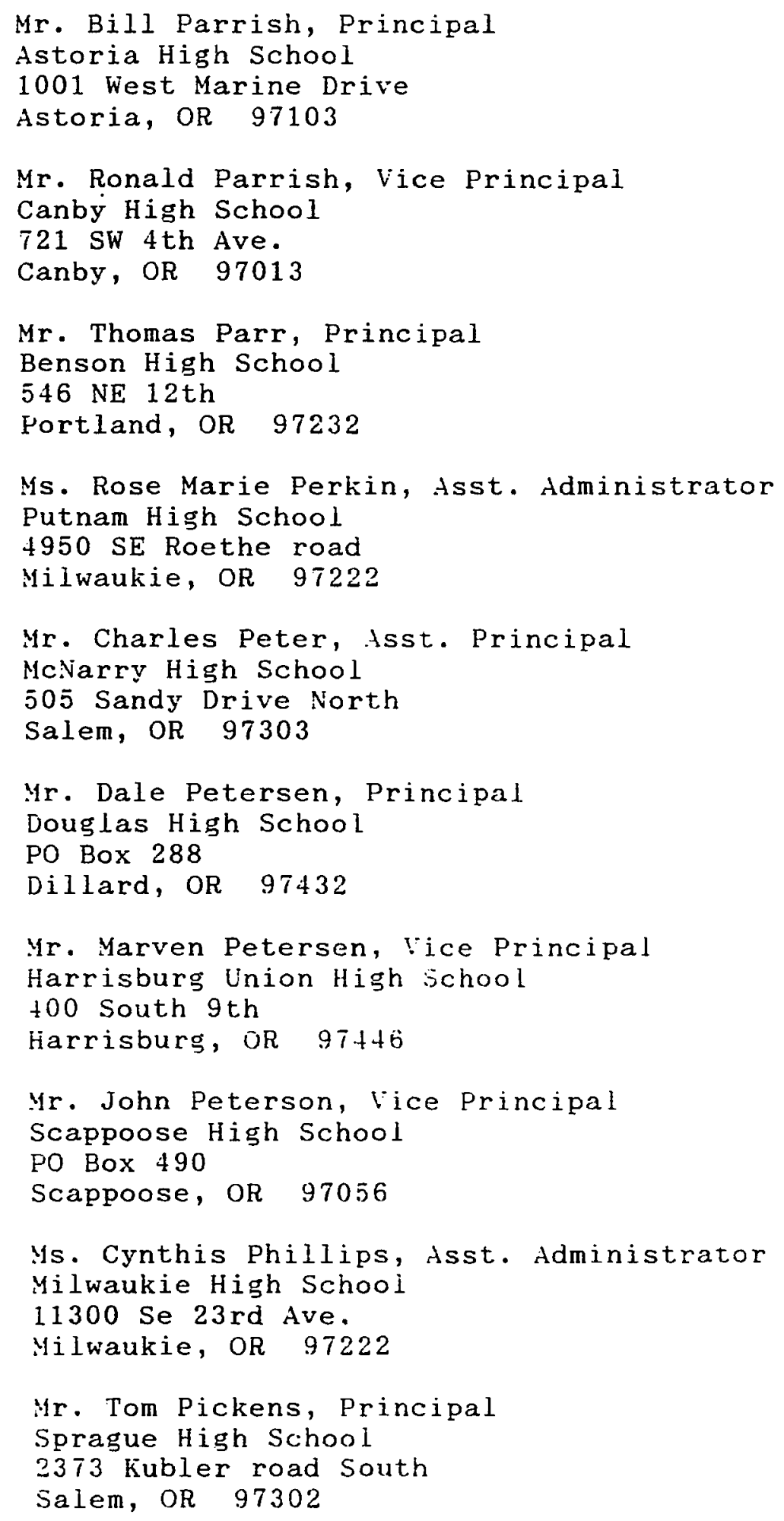




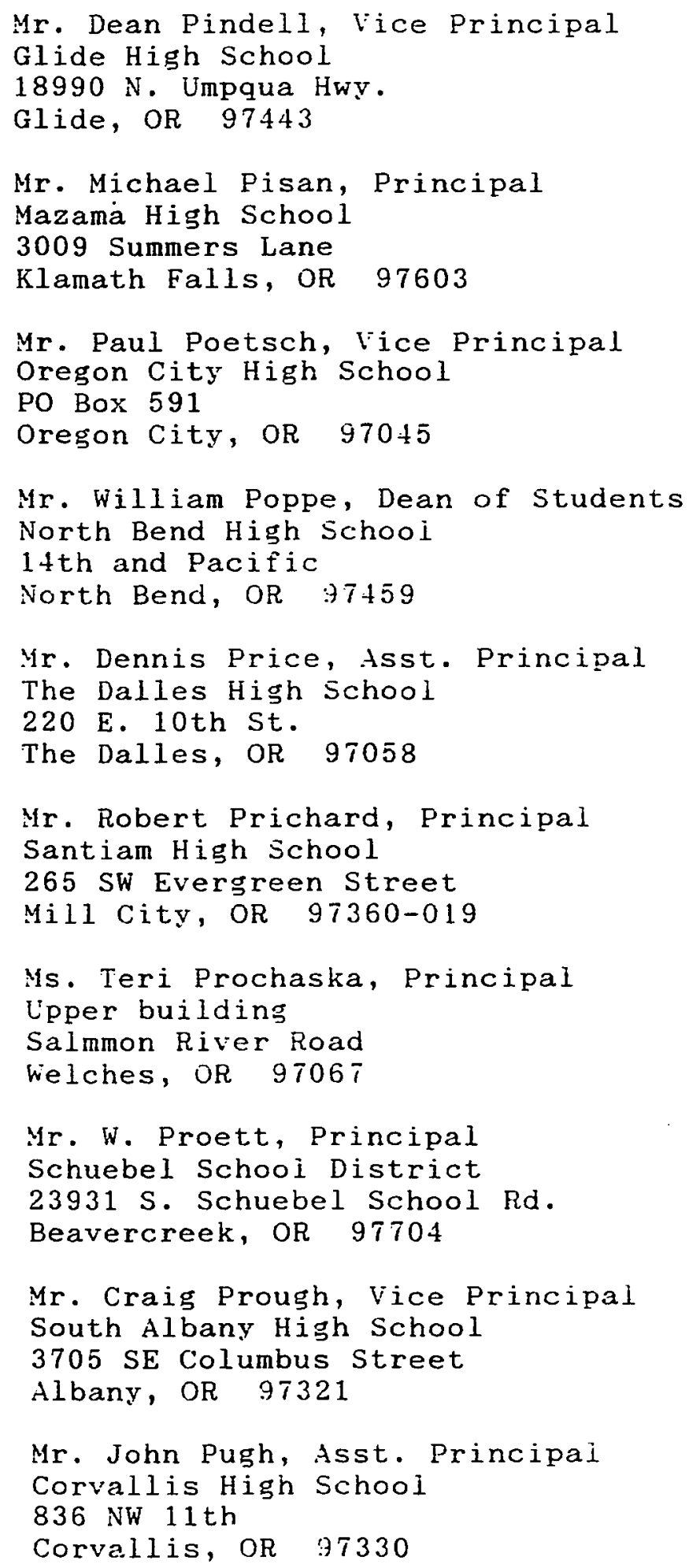


Mr. John Purcell, Asst. Principal North Medford High School

$1900 \mathrm{~N}$. Keeneway

Medford, OR 97504

Mr. John Purcell, Asst. Principal

North Medford High School

1990 Keeneway Drive

Medford, OR 97504

Mr. Dan Purple, Asst. Administrator

Clackamas High School

$13801 \mathrm{SE}$ webster Road

Milwaukie, OR 97267

Mr. Dennis Reber, Vice Principal

Sutherlin High School

PO Box 160

Sutherlin, OR 97479

Mr. Larry Reeser, Principal

LaPine High School

51633 Coach Road

LaPine, OR 97739

Mr. Richard Reiling, Principal

Lebanon Union High School

$485 \mathrm{~S}$. 5 th St.

Lebanon, OR 97355

Mr. Bernie Rainbold, iice Principal

Clatskanie High Schooi

PO Box 68

Clatskanie, OR 97016

Mr. Truman Rennels, Student Services

Eagie Point High School

PO Box 198

Eagie Point, OR 97524

Mr. Bruch Richards, Vice Frincipal

Lincoln High School

1600 SW Salmon

Portland, OR 97205

Mrs. S. Richards, Principal

Centennial High School

3505 SE $182 \mathrm{nd}$

Gresham, OR 97030 
Mr. Allen Ricketts, Principal

Silverton High Schooi

802 Schlador Street

Silverton, OR 97381

Mr. Lyle Rilling, Principal

Junction City High School

1135 w. 6th St.

Junction City, OR 97448

Mr. Charles Roberts, Asst. Principal

Madras High School

PO Box 649

Madras, OR 97741

Mr. Arnold Roblan, Vice Principal

Marshfield High Schooi

PO Box 509

Coos Bay, OR 97420

Ms. Sharon Rodgers, Vice Principal

Oregon City High Schooi

130612 th Street

Oregon City, OR 97045

Mr. Joseph Rodriguez, Principal

Glencoe High School

$2700 \mathrm{NW}$ Glencoe Road

Hillsboro, OR 97124

Mr. James Roehm, Yice Principal

Glencoe High School

$2 T 00$ Nir Glencoe Road.

Hilisboro, OR $9712 t$

Dr. Myra Rose, Principal

Grant High School

2245 NE 36 th

Portland, OR 97212

Mr. Greg Ross, Principal

Grants Pass High School

$522 \mathrm{NE}$ Olive St.

Grants Pass, OR 97526

Mr. Gary Rosso, Student Personnel

Seaside High Schooi

1901 N. Holladay

Seaside, OR 97138 


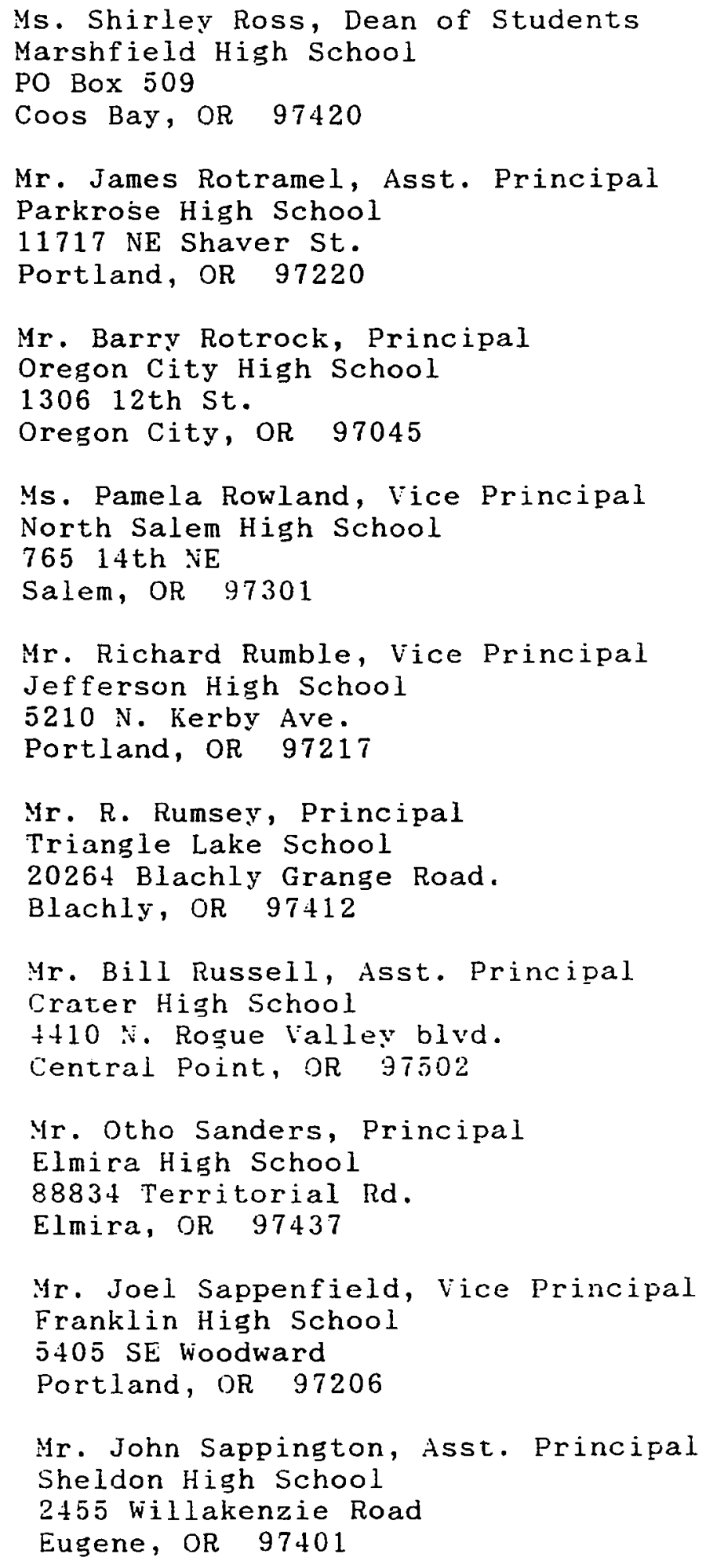


Mr. Roger Sauer, Principal

Seaside High School

1091 N. Holladay Drive

Seaside, OR 97138

Mr. James Savard, Dean Student Activities

Grants' Pass High School

522 NE Olive

Grants Pass, OR 97526

Mr. Brian Say, Principal

Echo High School

PO Box 359

Echo, OR 97826

Mr. Ronald Schiessl, Principal

Springfield High School

$875 \mathrm{~N}$. 7 th St.

Springfield, oR $97+7 \bar{\imath}$

Mr. Jeff Schlecht, Associate Principal

Ashland High Schooi

201 S. Mountain Ave.

Ashland, OR 97520

Mr. Robert Schlegel, Principal

Banks High School

PO Box 36

Banks, OR 97106

Mr. Karl Schmidt, Principal

Coquille High School

499 W. Central

Coquille, OR $97+23$

Mr. Charles Schubert, Asst. Principal

Klamath Union High School

Monclaire St.

Klamath Falls, OR $९ 7601$

Mr. Edward Schumacher, Principai

Echo School District

PO Box 359

Echo, OR 97826

Mr. James Schweigert, issistant Prircipal Astoria Figh School

1001 Marine Drive

Astoria, OR 97103 
Mr. Gary Seaney, Asst. Principal

Tillamook High School

260512 th St.

Tillamook, OR 97141

Mr. Charles Sharps, Principal

Marshfield High School

PO Box 509

Coos Bay, OR 97420

Mr. Stephan Sharp, Vice Principal

South Umpqua High School

$501 \mathrm{NW}$ Chadwick Lane

Myrtle Creek, oR $9745 i$

Mr. Bob Shieids, Vice Principal

Oregon City High School

130612 th St.

Oregon City, OR 97045

Mr. Michael Shields, Principal

Molalla High School

PO Box 188

Mollalla, OR 97038

is. Sue Shields, Asst. Administrator

Clackamas High School

$13801 \mathrm{SE}$ webster Road

Milwaukie, OR 97222

Mr. Maynord Simenson, Principal

Yonument High School

PO Box 127

Monument, OR 97864

Mr. Robert Simonson, Vice Principai

Klamath Union High School

Monclaire Street

Klamath Falls, OR 97601

Mr. James Sipe, Principal

Jordan Vailey High School

PO Box 163

Jordan vallev, OR 97910

Mr. Robert Sisk, Principal

Hidden Valley High Schooi

651 Murphy Creek Rd.

Grants pass, OR 97527 


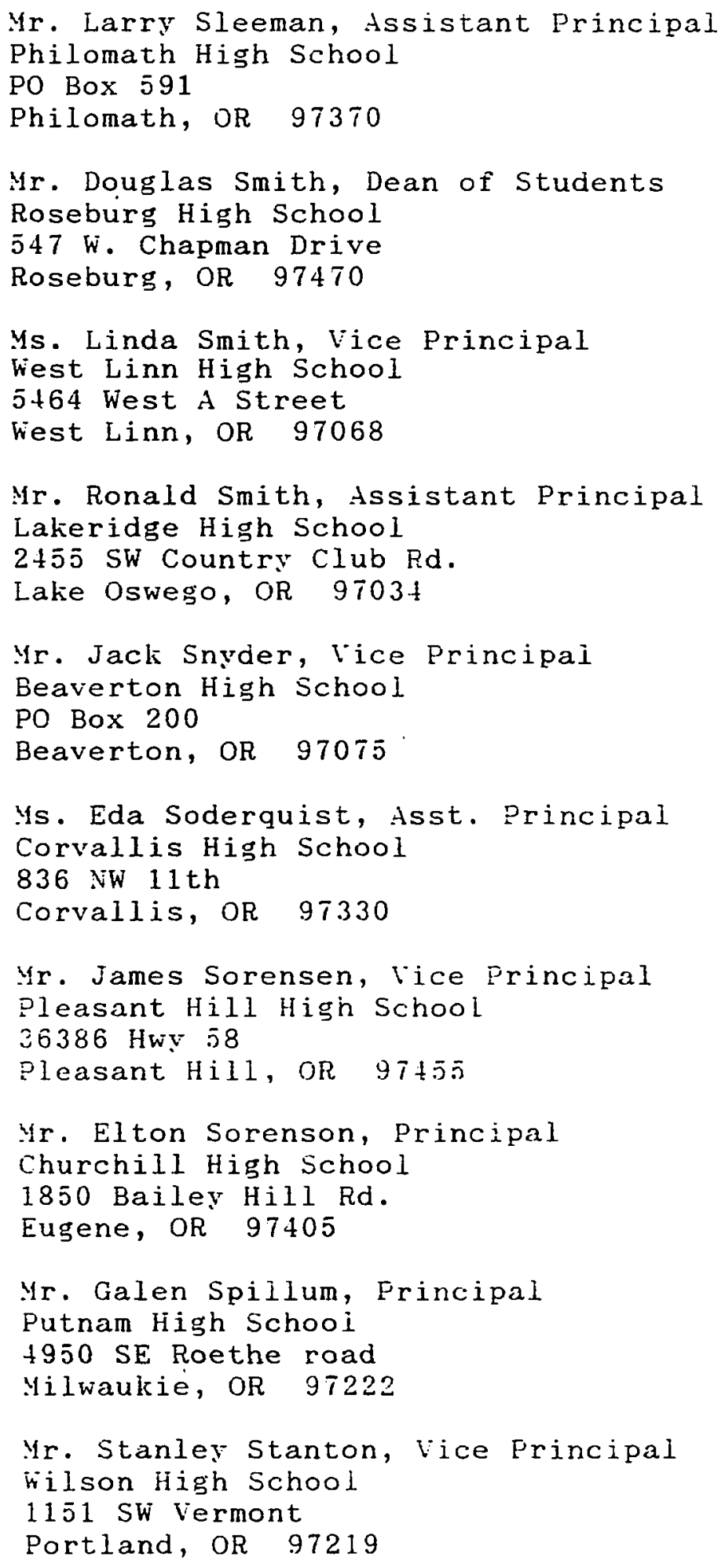




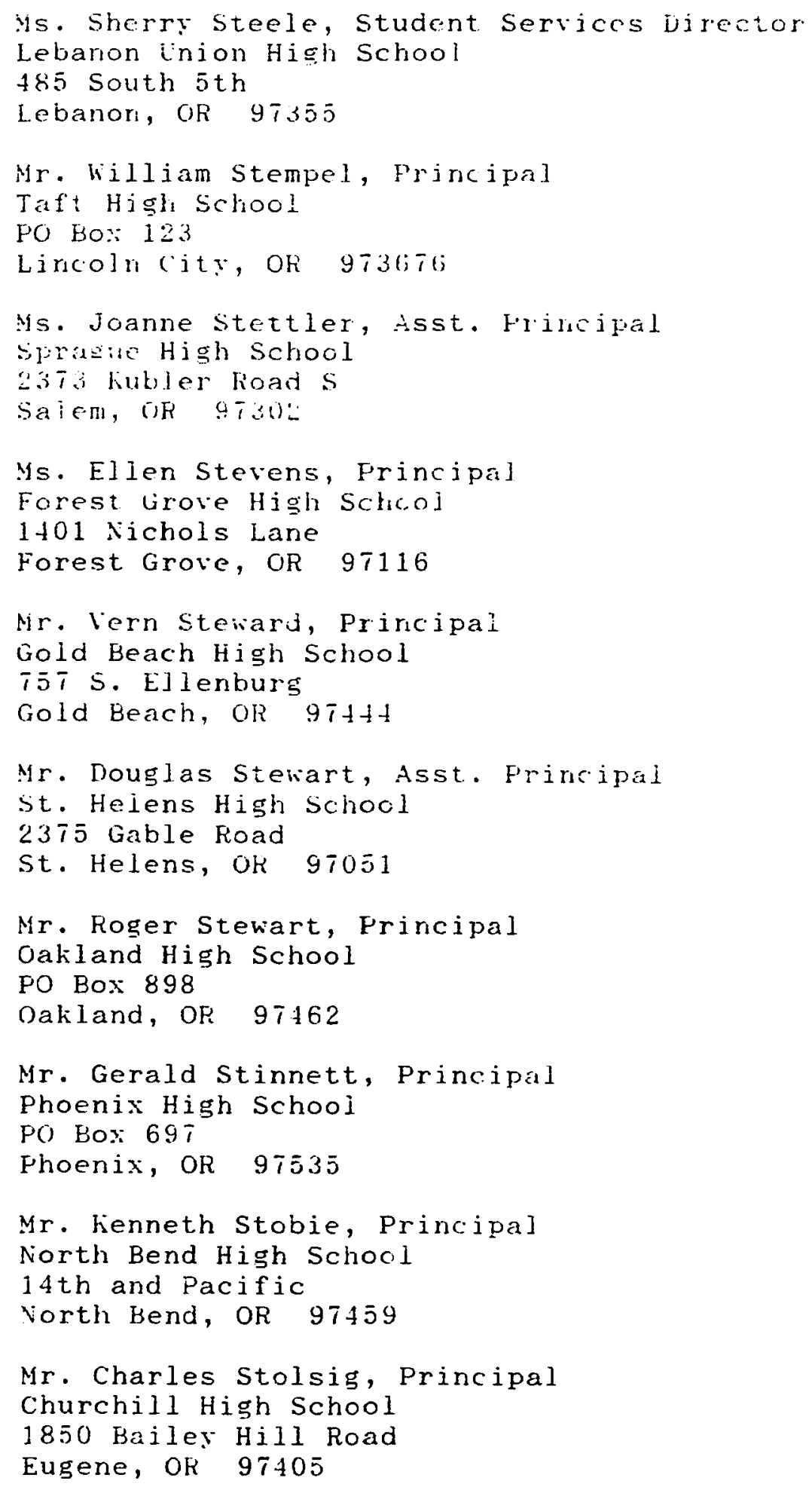




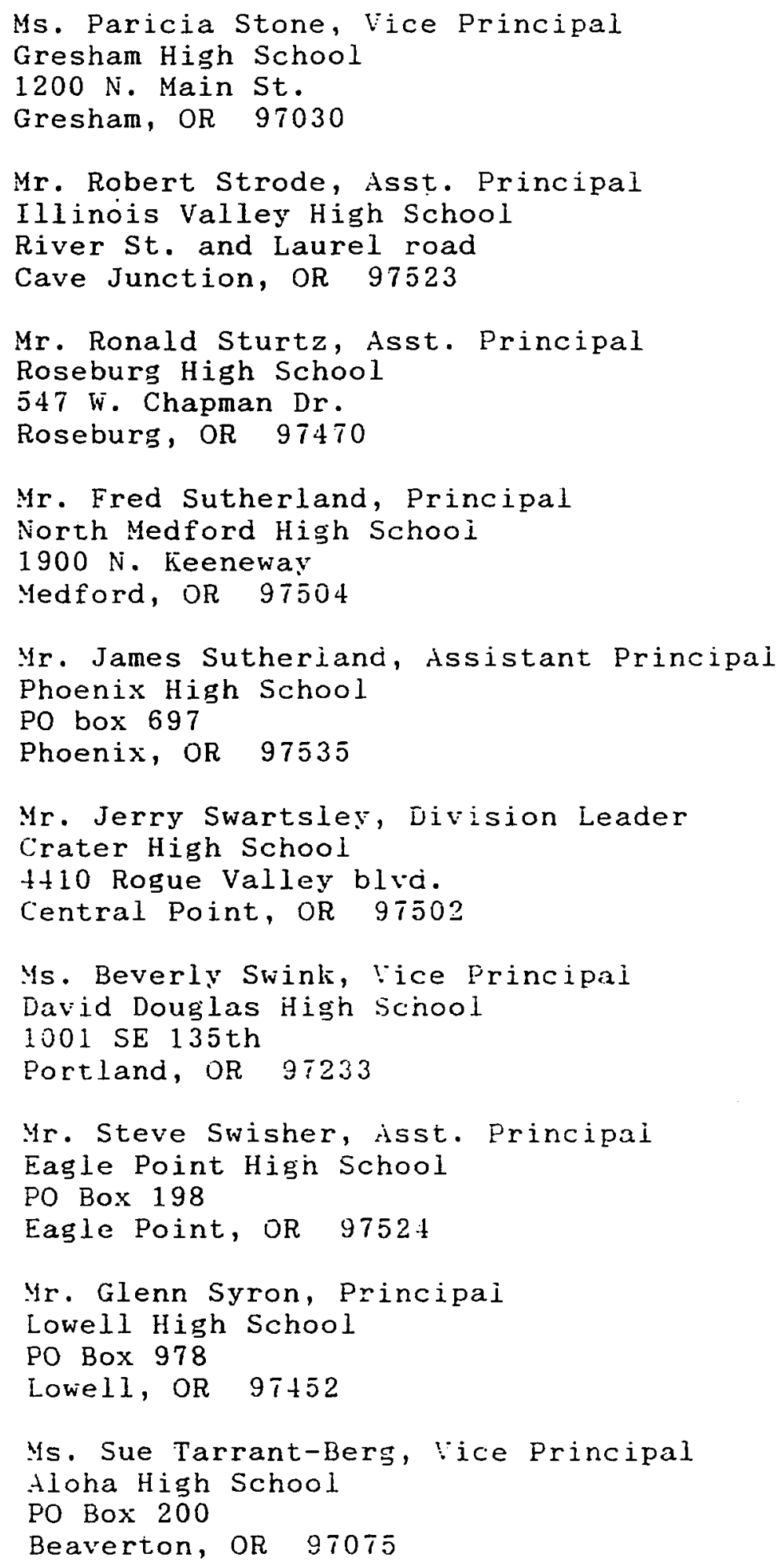




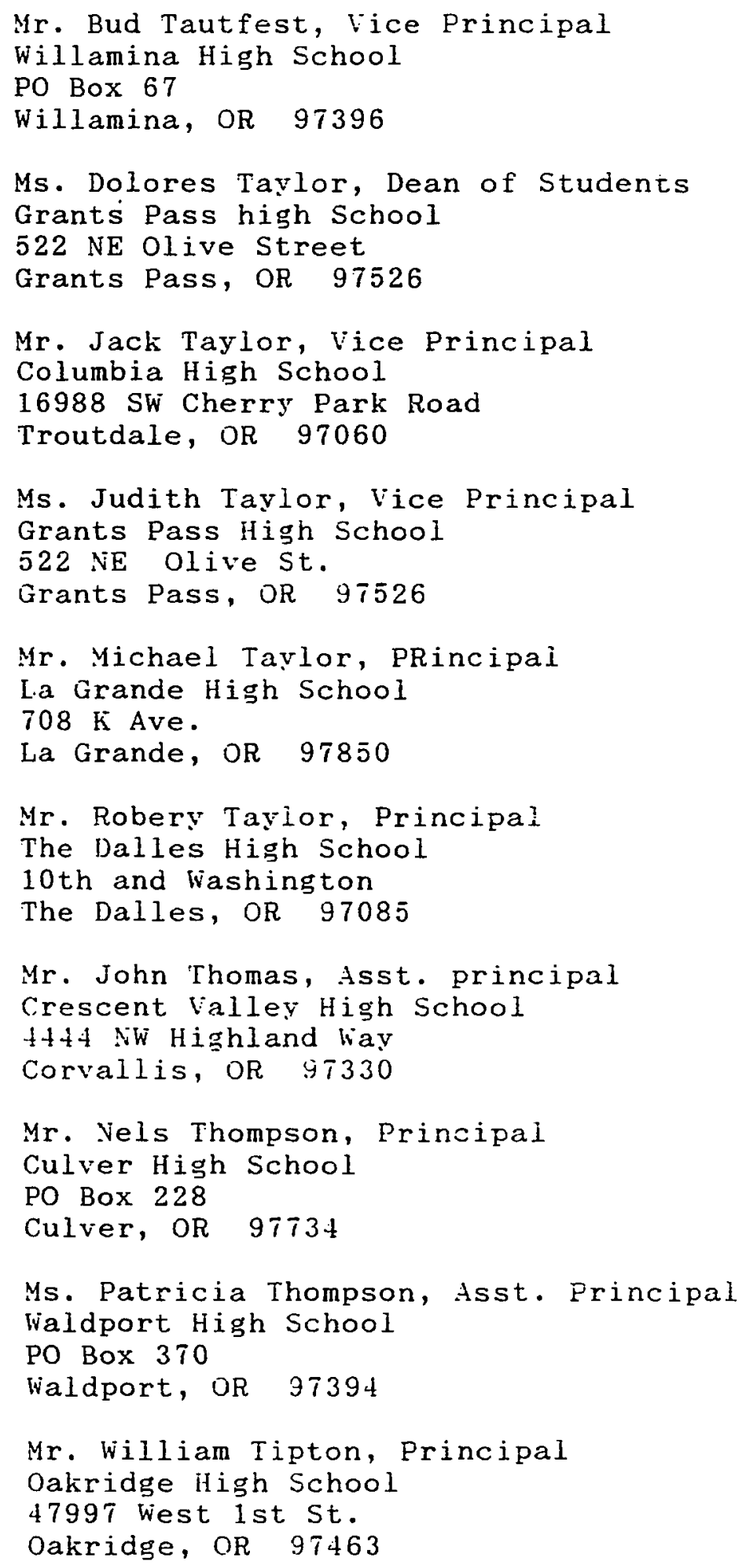




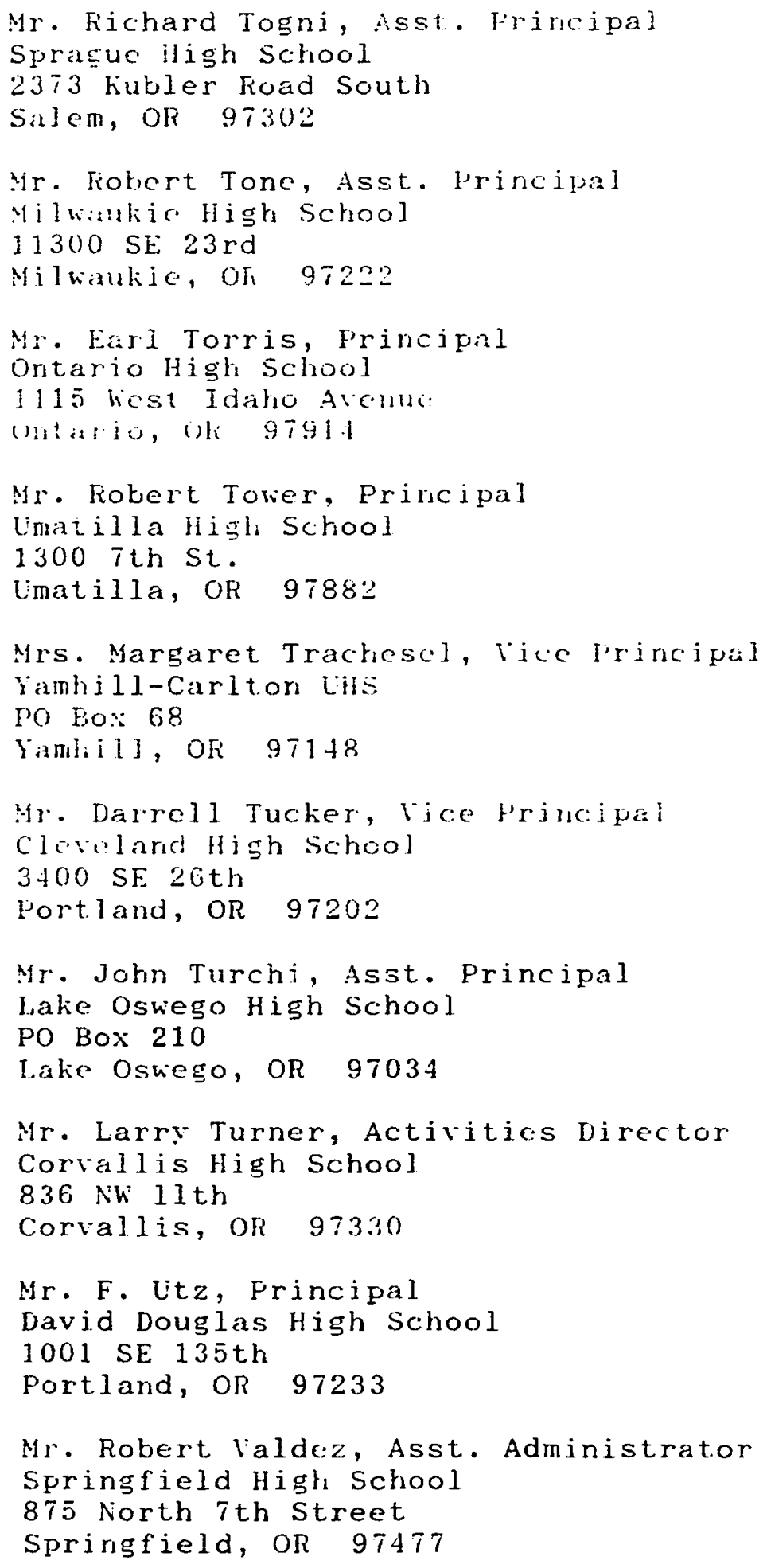




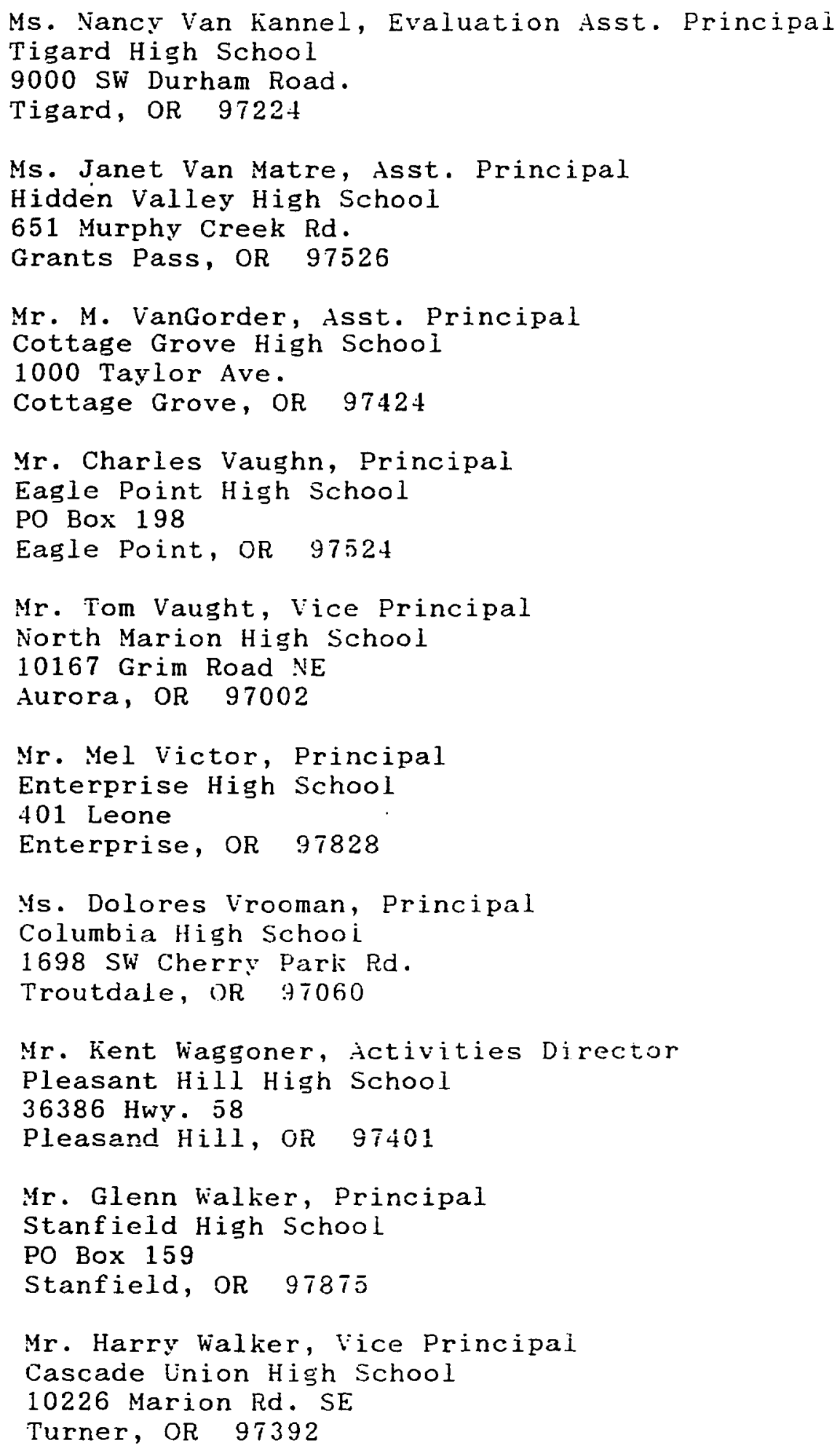




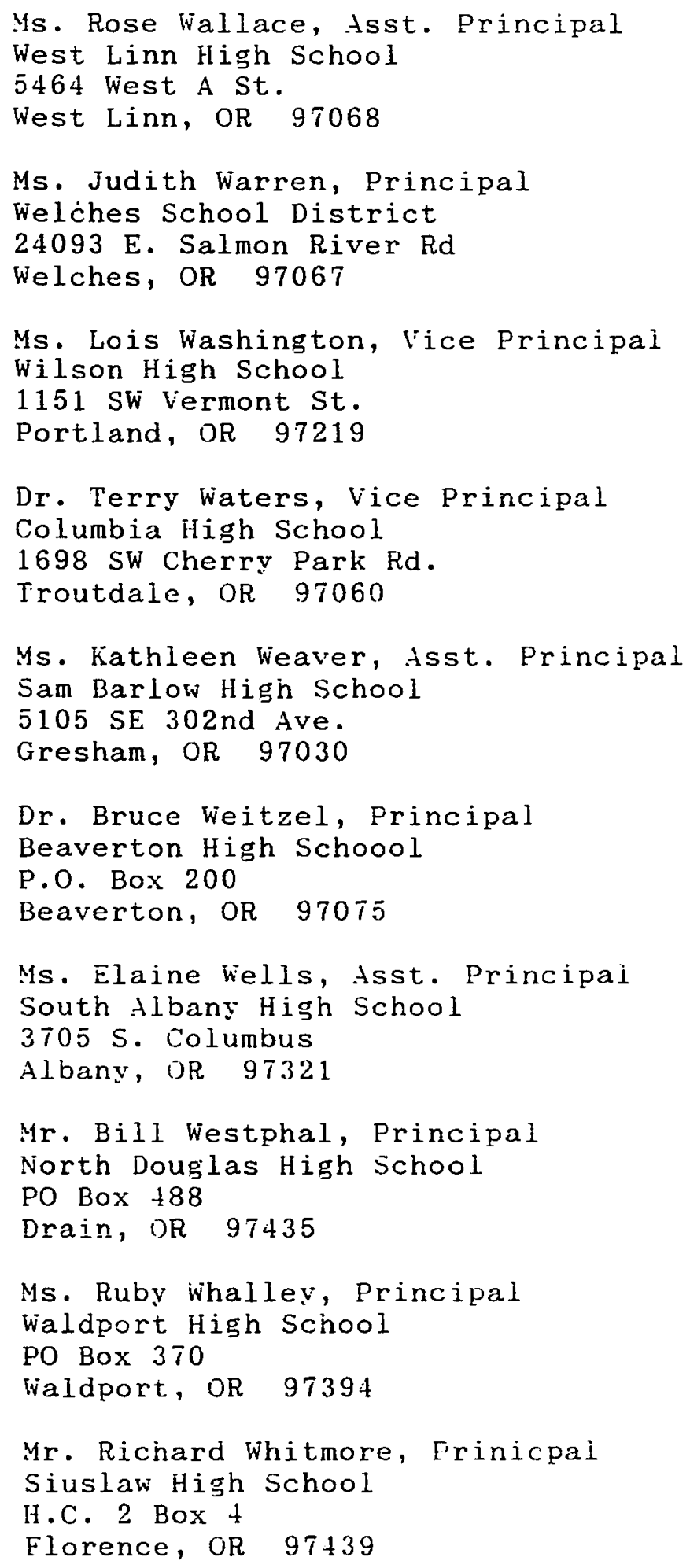


Mr. Kent wigle, Actirities Director

South Umpqua High School

501 NW Chadwick

Myrtle Creek, OR 97457

Mr. William Willey, Principal

Sherwood High School

1155 SW Meinecke Road.

Sherwood, OR 97140

Mr. A. Williams, Vice Principal

Jefferson High School

5210 North Kerby Ave.

Portland, OR 97217

Mr. Jack Williams, Assitant Administrator

Neah-Kah-Nie High School

PO Box 28

Rockaway, OR 97136

Mr. Ron ivilliams, tsst. Principal

South Medford High School

815 South Oakdale Ave.

Medford, OR 97501

Mr. Stephen williams, Principal

Santiam High School

PO Box 199

Mill City, OR 97360

Mr. Robert wilson, Vice Principal

Marshall Hish Schooi

3905 SE $91 \mathrm{st}$ ive.

Portland, IJR 37266

Mr. M. Winder, Principal

Clackamas High schooi

$13801 \mathrm{SE}$ webster Rd.

Milwaukie, OR 97222

Mr. Michael wittmaver, Principai

Estacada High School

PO Box 519

Estacada, OR 97023

Ms. Patricia wixon, isst. Principal

Ashland High School

201 S. Mountain Avenue

Ashland, OR 97520 
Mr. Gary Wood, Vice Principal

Molalla High School

PO Box 189

Molalla, OR 97038

Mr. Jack Woodhead, Vice Principal

Grants Pass High School

522 NE Olive

Grants Pass, OR 97526

Mr. Larry Wright, Asst. Principal

Canby Union High School

721 SW 4 th

Canby, OR 97013

Mr. Dale wyatt, Principal

La Grande High School

$708 \mathrm{~K}$ Ave.

La Grancie, OR 97850

Mr. Chris Yaeger, Principal

Chiloquin High Schooi

PO Box 397

Chiloquin, OR 97624

Mr. Don Yates, iice Principal

Willamina High School

266 washington St.

willamina, or 973.96

Mr. David Youngbluth, Principal

Bend High School

230 NE 6 th St.

Bend, OR 97701

Mr. Rob lounger, Vice Principal

Sweet Home High School

1641 Long St.

Sweet Home, OR 97386

Yr. Vincent Zanobelli, Principal

Bandon High School

PO Box 129

Bandon, OR 97411

Mr. Victor Zgorzellski, Asst. Principal

Sweet Home High School

1641 Long Street

Sweet Home, OR 97386 
Mr. Al Zimmerman, Principal

Tigard High School

9000 SW Durham Rd.

Tigard, OR 97224

Mr. Gary Zosel, Principal

Colton High School

30205 S. Wall Street

Colton, OR 97017 
APPENDIX E

POSTCARD SENT PRIOR TO QUESTIONNAIRE 
APPENDIX F

QUESTIONNAIRE COVER LETTER 
Dear Colleague:

You will soon be receiving a questionnaire that is part of a doctoral study entitled "An Analysis of the Role of the Assistant Principal in Obtaining Administrative Skills." Your input is extremely vital to the success of this study and I look forward to receiving your response.

Thank you.

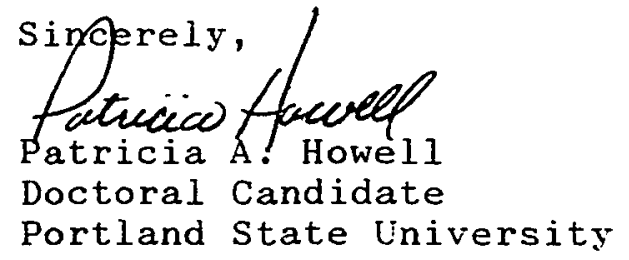




\section{Portland State University}

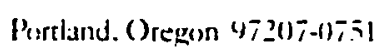

October 26, 1987

Dear Colleague:

We are currently seeking to analyze the administrative skills of the Assistant Principal as perceived by assistant principals and principals in the state of Oregon. As a member of the Confederation of Oregon School Administrators, you have been selected to participate in this study.

We need your help to determine what effect the present on-site duties of an assistant principal have in obtaining the necessary skills for professional advancement. Please complete the questionnaire and return it by November 16, 1987, in the enclosed postage-paid envelope.

Your prompt response will help us complete this very important research project. Thank you.

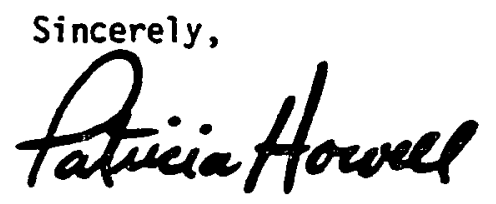

Patricia A. Howell

Doctoral Candidate

Portland State University

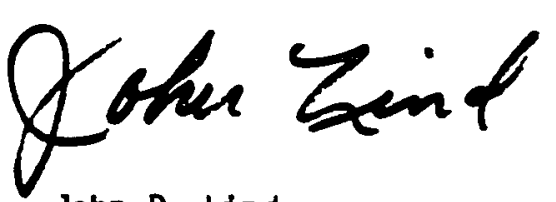

John D. Lind

Doctoral Advisor

PAH/JDL:mr

Enclosures 
APPENDIX G

QUESTIONNAIRE 
AN ANALYSIS OF THE ROLE OF THE ASSISTANT PRINCIPAL

IN OBTAINING ADMINISTRATIVE SKILLS

by

Patricia A. Howell

Submitted in Partial Fulfillment of the Requirements for

the Doctor of Education Degree

in Educational Leadership

School of Education

Portland State University

Portland, Oregon

October, 1987 


\section{QUESTIONNAIRE}

An Analysis of the Role of the Assistant Principal in Obtaining Administrative Skills

1. To what extent does the present job of an Assistant Principal at your high school prepare you for the role of a principal in the following areas: Please circle one response for each item.
A. discipline
B. curriculum development
C. budgetary processes
D. community relations
E. teacher supervision/evaluation
$F$. staff development
$G$. on-site building maintenance/operations
H. athletic supervision
I. activity supervision
J. school improvement
K. guidance and counseling
L. hiring/selection
M. special education
N. improvement of instruction
0 . other

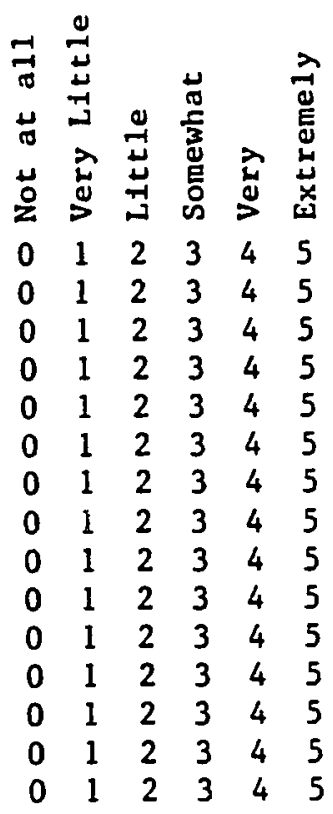

Comments

2. To what extent does there tend to be a stereotyping by sex as to the capability to perform assignments in the following roles. Please circle one response for each item.
A. discipline
B. curriculum development
C. budgetary processes
D. community relations
E. teacher supervision/evaluation
F. staff development
G. on-site building maintenance/operations
H. athletic supervision
I. activity supervision
J. school improvement
$K$. guidance and counseling
L. hiring/selection
M. special education
N. improvement of instruction
0 . other
Comments

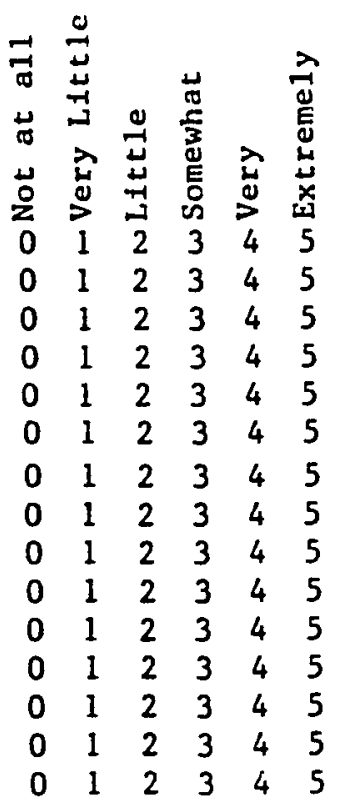


3. To what extent do teacher supervision/ evaluation duties prepare the Assistant Principal to evaluate new personnel within the scope of district policies? Please circle one response

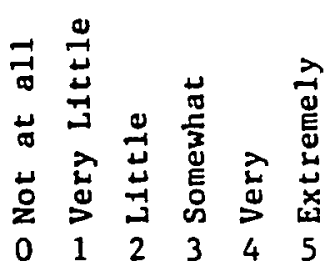

Comments

4. To what degree does the job prepare the Assistant Principal to handle staff complaints and problems? Please circle one response.

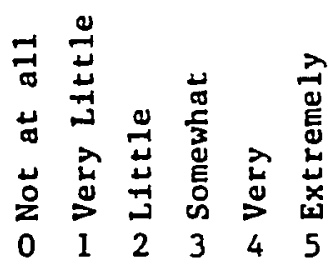

Comments

5. What effect does the size of the administrative staff have on the depth in which the Assistant Principal is able to understand the complexity of job assignments given to him/her? Please circle one response.

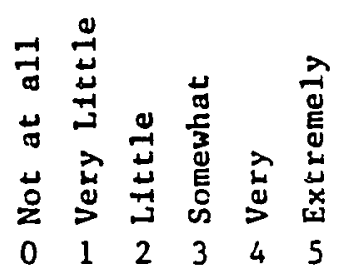

Couments

6. To what extent do you feel there needs to be clarification as to the exact role of the Assistant Principal? Please circle one response.

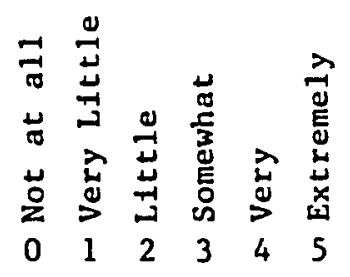

Comments

7. To what degree do you belleve being an Assistant Principal in and of itself can be a satisfactory professional goal? Please circle one response.

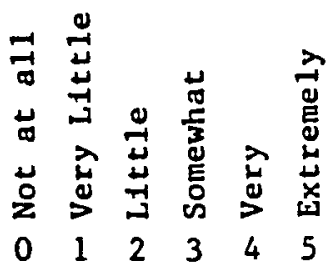

Comments 
8. To what degree does the number of assignments given each Assistant Principal effect his/her ability to obtain administrative skills? Please circle one response.

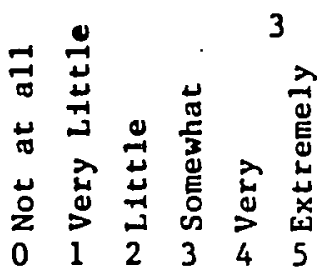

Comments

9. To what degree does specialization in the job assignment of an Assistant Principal become a factor in his/her obtaining needed administrative skills for advancement? Please circie one response.

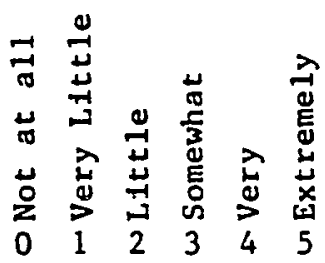

Comments

10. To what degree does an Assistant Principal have professional interaction with individuals that he/she would have to interact with as a principal? Please circle one response.

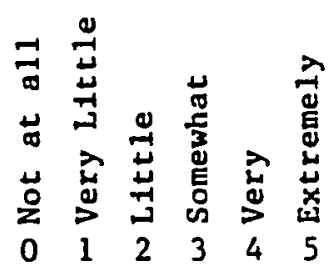

Comments

11. To what extent do the Assistant Principal and the Principal communicate with each other as to the value of the Assistant Principal's role in preparing to become a principal?

Please circle one response.

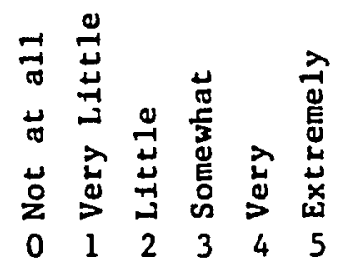

Comments

12. To what extent do the experiences of an Assistant Principal provide adequate and appropriate preparation for a principalship? Please circle one response.

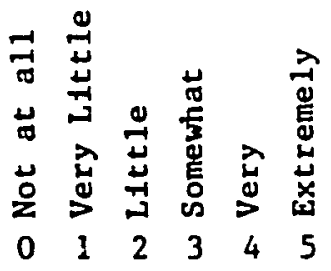

Comments 
The following demographic questions will be used to ascertain the effects of independent factors on the central issue of the study.
A. Male
Female

B. Assistant Principal

Principal

C. Number of years of experience in present position:

$0-3$

4-7

over 7

D. If Principal, number of years of experience as an Assistant Principal before being promoted to Principal:
$1-3$
4-7
over 7
NA

E. Recommended number of years of experience as an Assistant Principal before being promoted to Principal:
$0-3$
4-7
over 7

F. Number of Assistant Principals in building:
$0-1$
$2-3$
4 or over

G. Please indicate the vajor job assignments in your position:

\begin{tabular}{ll}
$-\begin{array}{l}\text { discipline } \\
\text { curriculum development } \\
\text { budgetary processes } \\
\text { athletic supervision } \\
\text { activity supervision } \\
\text { guidance and counseling }\end{array}$ & $\begin{array}{l}\text { community relations } \\
\text { teacher supervision/evaluation } \\
\text { staff development }\end{array}$ \\
$-\begin{array}{l}\text { special education } \\
\text { other }\end{array}$ & $-\begin{array}{l}\text { on-site building maintenance/operations } \\
\text { hiring/selection }\end{array}$ \\
\hline
\end{tabular}


APPENDIX $\mathrm{H}$

FOLLOW-UP POSTCARD

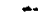


Dear Colleague:

Thank you for responding to the recent questionnaire concerning the analysis of the role of the assistant principal in obtaining administrative skills. I sincereiy appreciate your time and interest in being a part of the study.

If you have not completed and returned the questionnaire, I would appreciate vour timely response. Thank you.

Sincerely,

Patricia A. Howell

Doctoral Candidate

Portland State liniversity 